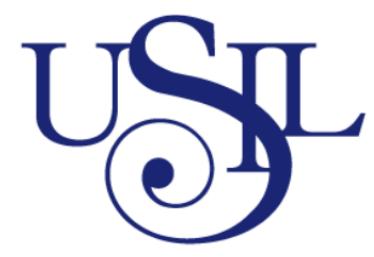

UNIVERSIDAD

SAN IGNACIO

DE LOYOLA

FACULTAD DE DERECHO

Carrera de Derecho

\title{
INDEMNIZACIÓN POR EJECUCIÓN DE MEDIDAS CAUTELARES EN EL ARBITRAJE COMERCIAL DOMÉSTICO PERUANO
}

Tesis para optar por el título profesional de Abogado.

\section{MARIA ANGELICA ROBLES MEZA}

\author{
Asesor: \\ Ricardo Beaumont Callirgos \\ Lima - Perú \\ 2020
}




\section{Dedicatoria}

El presente trabajo es dedicado a mis queridos padres y a la vez abuelos, Isidro y María, quienes me cuidan desde el cielo. A Jenny, Marcos, mi familia por su amor. A mis profesores, de quienes aprendí en aulas y a través de la lectura. Estaré eternamente agradecida por haberme guiado hasta aquí. 


\section{Contenido}

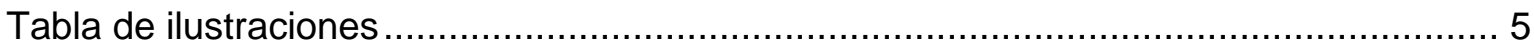

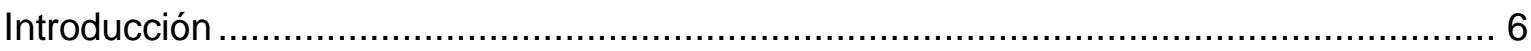

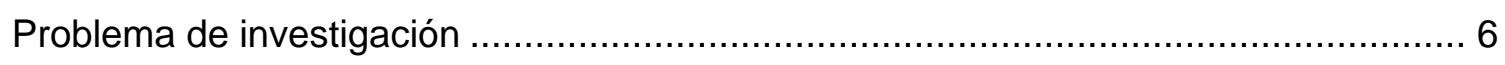

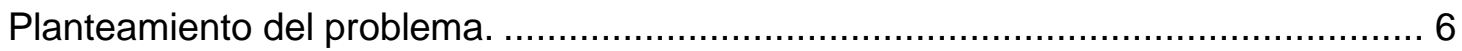

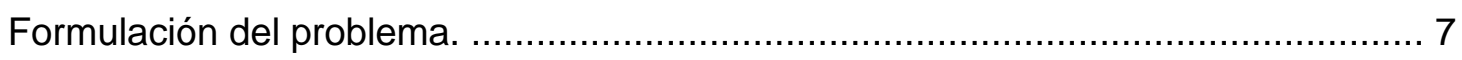

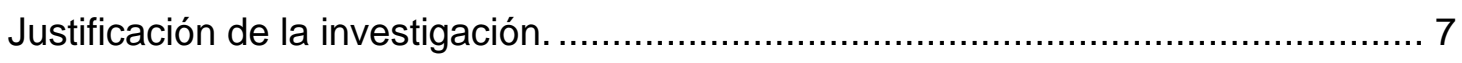

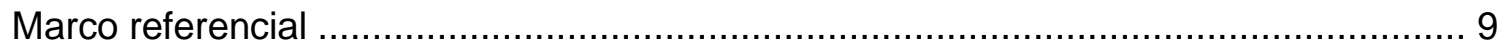

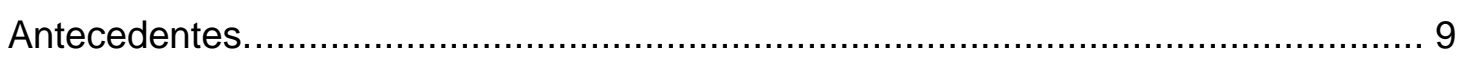

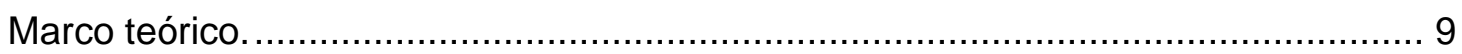

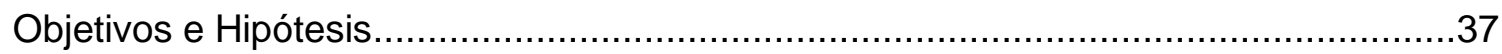

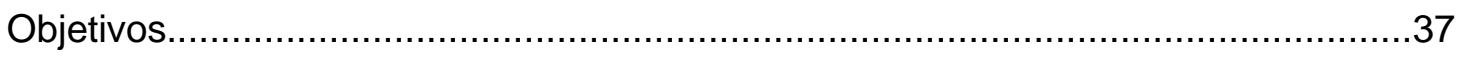

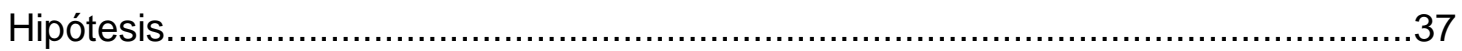

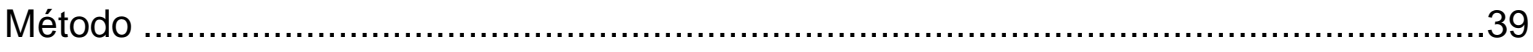

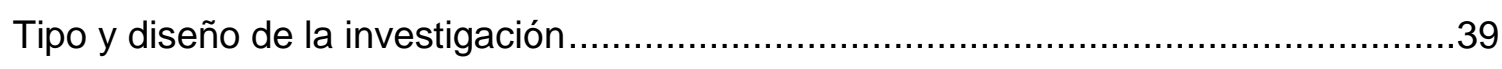

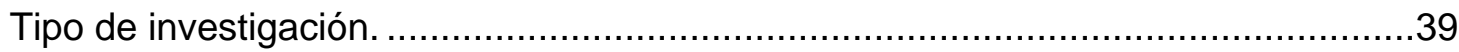

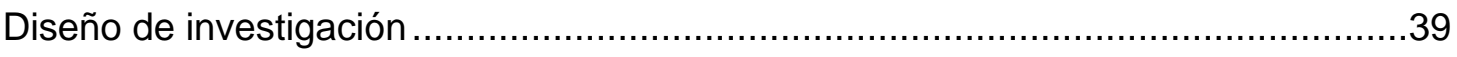

Instrumentos de investigación. ................................................................. 40

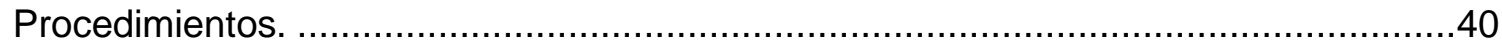

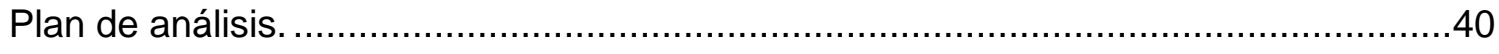

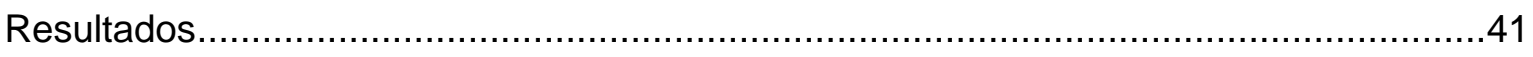

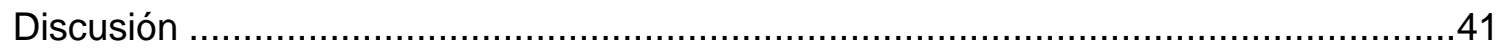

La discusión sobre la responsabilidad por el perjuicio que ocasione la ejecución de una medida cautelar ¿excede de lo pactado por las partes al celebrar un convenio arbitral que señala que aquellas controversias que deriven de determinada relación jurídica se resolverán a través de arbitraje?.....

¿Cómo es otorgada la indemnización por los daños ocasionados en virtud de la ejecución de una medida cautelar? 
¿Cuál es el procedimiento y las particularidades procesales para la discusión sobre los perjuicios de la ejecución de una medida cautelar en el arbitraje? .45

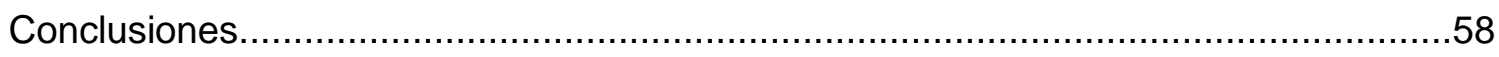

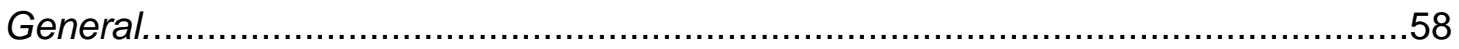

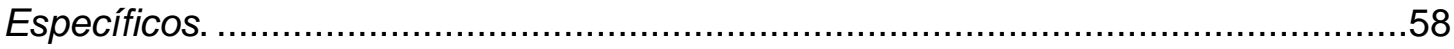

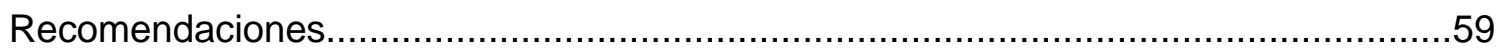

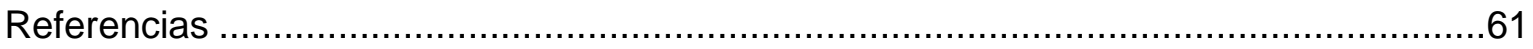

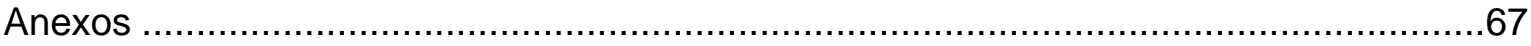

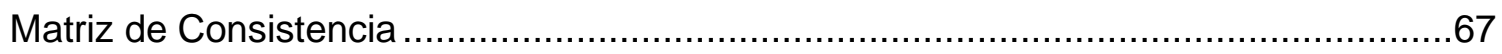

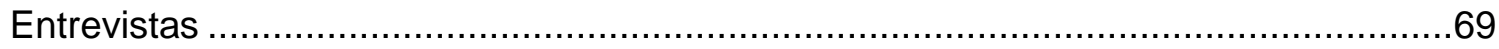

Entrevista al profesor Hector Campos García.....................................................69

Entrevista al profesor Daniel Linares Prado....................................................78

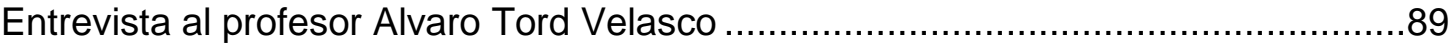


Tabla de ilustraciones

Ilustración 1: Procesos en trámite en el Poder Judicial Peruano .......................................42

llustración 2: Demandas ingresadas y resueltas el Poder Judicial Peruano ......................43

Ilustración 3: Demandas ingresadas y resueltas el Poder Judicial Peruano ......................43 


\section{Introducción}

\section{Problema de investigación}

\section{Planteamiento del problema.}

El propósito del presente trabajo es explorar lo establecido a través del numeral 8 del artículo 47 de la ley que regula el arbitraje, Decreto Legislativo № 1071, en específico, la facultad que se le otorga al tribunal arbitral de determinar que una medida cautelar no debió haberse otorgado, y que en tal caso, éste requiera al solicitante el pago por los daños que la medida haya provocado, siempre que el tribunal arbitral sea competente.

Sobre esta disposición legal, surgen diferentes interrogantes en relación a su interpretación como, si esta facultad excede o no de lo pactado por las partes al celebrar un convenio arbitral que señala que aquellas controversias que deriven de determinada relación jurídica se resolverán a través de arbitraje, si es otorgada a pedido de parte o de oficio y cuál es el procedimiento para dilucidar dicha controversia.

Para lograr dar respuesta a la interrogante, se investigará sobre el convenio arbitral, la competencia de los tribunales arbitrales para resolver conflictos, medidas cautelares, interpretación, entre otros. Luego de ello, propondremos hipótesis que respondan a las preguntas señaladas en el párrafo anterior.

Por último, en relación al método que se utilizará en la investigación será de carácter descriptivo, según el nivel de complejidad de estudio y cualitativo por el tipo de análisis de la información. 


\section{Formulación del problema.}

\section{Problema General}

¿Cómo se puede interpretar el numeral 8 del artículo 47 de la ley que regula el arbitraje, Decreto Legislativo N 1071, en específico la facultad del tribunal arbitral de requerir el pago de los daños ocasionados por la ejecución de una medida cautelar?

\section{Problemas Específicos}

1. La discusión sobre la responsabilidad por el perjuicio que ocasione la ejecución de una medida cautelar ¿excede de lo pactado por las partes al celebrar un convenio arbitral que señala que aquellas controversias que deriven de determinada relación jurídica se resolverán a través de arbitraje?

2. ¿Cómo es otorgada la indemnización por los daños ocasionados en virtud de la ejecución de una medida cautelar?

3. ¿Cuál es el procedimiento y las particularidades procesales para la discusión sobre los perjuicios de la ejecución de una medida cautelar en el arbitraje?

\section{Justificación de la investigación.}

El presente trabajo se justifica en que actualmente existen problemas en relación a la interpretación de un dispositivo legal, inciso 8 del artículo 47 de la Ley que regula el arbitraje, Decreto Legislativo $N^{\circ} 1071$, como lo es la falta de un procedimiento para condenar la indemnización por ejecución de medidas cautelares, lo cual podría ocasionar incertidumbre al encontrarse en el supuesto en que se considere que la medida cautelar no debió haberse otorgado.

Por tal motivo, se tiene como objetivo descubrir cuáles son los resultados del análisis de este dispositivo de manera sistemática y no aisladamente, y cuáles serían las más adecuadas.

Cabe señalar que del tema de la presente investigación pueden surgir otras controversias, como en el supuesto en el que el tribunal arbitral que conozca el conflicto principal, otorgue una medida cautelar, dado que ello podría originar un conflicto respecto de su imparcialidad. (Ariano, 2013), así como la responsabilidad de la autoridad que concedió la medida cautelar al determinarse que la misma no debió haberse otorgado. En ese sentido, con la finalidad de evitar sesgos cognitivos, solo se desarrollarán los problemas señalados precedentemente. 
Los beneficiados de manera directa de estas mejoras serán las partes de los procesos arbitrales e indirectamente aquellos interesados en el estudio del arbitraje. 


\section{Marco referencial}

\section{Antecedentes.}

Del análisis del inciso 8 del artículo 47 de la ley que regula el arbitraje, Decreto Legislativo 1071, se verifica que el tribunal arbitral está facultado para requerir al solicitante de una medida cautelar indemnizar por los daños que se ocasionen la medida en cualquier momento del proceso. Ello podría ser un problema muy serio, pues ésta condena es ultra petita. Este conflicto debería dilucidarse en otro proceso ya sea judicial o arbitral de no ser suficiente el monto de la contracautela ofrecida. Por otro lado, es insólito este otorgamiento de indemnización, dado que aparentemente no se ejercería contradicción entre las partes, así como la falta de ofrecimiento de medios probatorios. Motivo por el cual, podríamos afirmar que es de carácter arbitrario, al tener el tribunal total discreción. (Castillo, Sabroso, \& Chipana, 2013)

\section{Marco teórico.}

El arbitraje.

El arbitraje, en palabras de Montero Roca, es una institución jurídica heterocompositiva, en la que un tercero, quien deberá ser objetivo e imparcial, decide con base a una potestad específica el conflicto intersubjetivo de intereses jurídicos, la cual debe ser una materia susceptible de libre disposición por las personas afectadas por la controversia. (Montero, 1995)

Asimismo, Guillermo Lohmann define al arbitraje como la institución que regula el acuerdo de voluntades por el cual se decide someter a una o terceras personas, quienes, de aceptar el encargo, solucionarán cierto conflicto, el cual las partes tienen capacidad de disposición, obligándose previamente a no llevar la controversia a los tribunales ordinarios. (Lohmann, 1988)

Naturaleza jurídica del arbitraje.

En relación a su naturaleza, surgen las siguientes teorías: contractual, jurisdiccional y mixta.

Teoría contractual. 
En la teoría contractual se considera que el arbitraje es un contrato. "El convenio arbitral nace de la voluntad de las partes, ello permite que surja esta institución y se desarrolle". (Ledesma, 2010, pág. 30)

En ese mismo orden de ideas, Bullard afirma "Lo que llamamos proceso arbitral no es otra cosa que la ejecución de ese contrato. Su origen es el acuerdo y no la delegación del Estado para administrar justicia”. (Bullard, 2012, pág. 20)

De igual manera, Gary Born, sobre el particular señala:

The "contractual" school of thought regarded arbitration as a form of contractual relations. (...) The contractualist school emphasized that arbitrators were not judges (since they performed no "public" function and exercised no powers on behalf of the state). In general terms, the contractualist school placed primary emphasis on the role of party autonomy in the arbitral process. [La escuela contractual considera al arbitraje como una relación contractual. Esta enfatiza que los árbitros no son jueces (dado que no desempeñan una función pública y no ejercen poderes en nombre del Estado). En líneas generales, la escuela contractual enfatiza el rol de la autonomía de las partes en un proceso arbitral.] (Born, 2009, pág. 185)

Sin embargo, como señala Cantuarias, "el problema de esta teoría es desconocer que el arbitraje también depende del reconocimiento estatal. De lo contario, el laudo no tendría otro valor más que el del contrato". (Cantuarias \& Repetto, 2014, pág. 101)

\section{Teoría Jurisdiccional.}

Respecto a esta teoría, es pertinente explicar previamente que es jurisdicción, Caivano señala "La jurisdicción en sentido estricto, consiste en el ejercicio de una función cuyo objetivo es solucionar pacíficamente los conflictos sometidos a la decisión de un órgano que tenga competencia para resolverlos" (Caivano J. , 2008, pág. 92)

De acuerdo con, Lew, Mistelis y Kröll:

The jurisdictional theory relies on the state power to control and regulate arbitrations which take place within its jurisdiction. The interpretation and application of the law and the determination of disputes is a sovereign function normally exercised by national courts established by the state for that purpose. Parties can only submit to arbitration to the extent expressly allowed or accepted implicitly by the law of the place of arbitration. According to the jurisdictional 
theory, the state allows within its territory privately administered justice systems (delegated justice or parallel justice) by way of assignment or tolerance. This follows from the legal effect which a state and its legal system attaches to an arbitration agreement and to an arbitration award. Consequently, arbitrators exercise a public function. [La teoría jurisdiccional se basa en que el poder del estado para controlar y regular arbitrajes que tienen lugar dentro de jurisdicción. La interpretación y aplicación de la ley y la determinación de las disputas es una función soberana que normalmente es ejercida por tribunales nacionales establecidas por el Estado para ese propósito. Las partes solo pueden someterse a arbitraje expresamente o implícitamente por la ley del lugar del arbitraje. De acuerdo con esta teoría, el Estado permite dentro de su territorio sistemas de justicia de administración privada, mediante asignación o tolerancia. Esto se desprende del efecto legal en el que un Estado y su sistema legal reconocen un convenio arbitral y un laudo arbitral. En consecuencia, los árbitros ejercen una función pública. (Lew, Mistelis, \& Kröll, 2003, págs. 73-74)

El Tribunal Constitucional, a través del expediente 6167-2005-PHC/TC, fundamento 11 señalan:

Es justamente, la naturaleza propia de la jurisdicción arbitral y las características que la definen, las cuales permiten concluir a este Colegiado que no se trata del ejercicio de un poder sujeto exclusivamente al derecho privado, sino que forma parte esencial del orden público constitucional. La facultad de los árbitros para resolver un conflicto de intereses no se fundamenta en la autonomía de la voluntad de las partes del conflicto, prevista en el artículo $2^{\circ}$ inciso 24 literal a de la Constitución, sino que tiene su origen y, en consecuencia, su límite, en el artículo 139º de la propia Constitución. (Tribunal Constitucional, 2006)

Esta teoría se fundamenta en que el arbitraje no depende de la voluntad de las partes, su función es jurisdiccional porque la ley así lo indica, pues el Estado delega su facultad de resolver conflictos, sin este reconocimiento el arbitraje no se podría desenvolver.

Teoría mixta.

Por último, la teoría mixta o ecléctica considera al arbitraje como una institución de naturaleza contractual, en su origen, pero jurisdiccional en sus efectos. (Ledesma, 2010) 
Gary Born ha expuesto sobre esta teoría:

Although deriving its effectiveness from the agreement of the parties, as set out in the arbitral agreement, [arbitration] has a jurisdictional nature involving the application of the rules of procedure. This school offered comparatively little analysis as to what characteristics arbitration "should" demonstrate, focusing instead on the parties' autonomy. [En lugar de derivar su eficacia del acuerdo de las partes, como se establece en el acuerdo arbitral, [el arbitraje] tiene un carácter jurisdiccional que implica la aplicación de las reglas de procedimiento. Esta escuela ofreció poco análisis sobre las características que el arbitraje "debería" demostrar, centrándose en cambio en la autonomía de las partes.] (Born, 2009, pág. 186)

Compartimos esta última teoría, dado que no se puede negar que el origen del arbitraje es la autonomía de voluntad de las partes de resolver sus conflictos ante un tercero y que el mismo no sea dilucidado ante la justicia estatal, sin embargo, se necesita el reconocimiento estatal de jurisdicción para que las decisiones que se tomen durante el proceso arbitral puedan ser eficaces.

Como indica el profesor Cantuarias respaldando esta teoría: "En otras palabras, es el marco legal el que sin duda alguna, al reconocer de manera expresa la autonomía de voluntad de las partes plasmada en un convenio arbitral, limita la intervención judicial" (Cantuarias \& Repetto, 2014, pág. 105)

Convenio arbitral.

Mediante el numeral 1, del artículo 13 del Decreto Legislativo N 1071, se define al convenio arbitral de la siguiente manera:

El convenio arbitral es un acuerdo por el que las partes deciden someter a arbitraje todas las controversias o ciertas controversias que hayan surgido 0 puedan surgir entre ellas respecto de una determinada relación jurídica contractual o de otra naturaleza. (Congreso de la República del Perú, 2008)

Roque J. Caivano explica que el convenio arbitral es el sometimiento de las partes a lo que resuelva el tribunal arbitral, sobre aspectos que los mismos hayan decidido, asignando funciones y facultades a éste último, lo que significaría una renuncia a resolver esas controversias por los tribunales de justicia. (Caivano J. , 2013) 
Y como consecuencia de celebrar el convenio arbitral, se producirán dos efectos principales. Por un lado, los jueces estatales no tendrán competencia para conocer y decidir sobre los conflictos que hayan sido sometidos a ese convenio (efecto negativo) y por el otro, se atribuirá jurisdicción a los árbitros con el objetivo de que resuelvan las controversias que se hayan sometido al convenio, incluyendo sobre su competencia (efecto positivo). (Caivano J. , 2013)

Sin perjuicio de lo señalado, conforme la séptima disposición complementaria de la ley peruana de arbitraje, Decreto Legislativo 1071: "Mediante estipulación testamentaria puede disponerse el sometimiento a las controversias que puedan surgir entre los sucesores, o de ellos con sus albaceas, incluyendo las relativas al inventario de la masa hereditaria, su valoración, administración y partición" (Congreso de la República del Perú, 2008)

Podemos denominar el enunciado citado como "arbitraje sucesorio", el cual Luciano Barchi señala sobre el particular, que éste no es un consenso entre las partes, sino un acto jurídico unilateral, en el cual el testador establece que conflictos que podrían surgir entre los sucesores y/o albaceas se dilucidarán a través de arbitraje. En ese sentido, es un tercero (no las partes del proceso arbitral) quien determinará acudir a un arbitraje. En consecuencia, el denominado arbitraje sucesorio no se encuentra dentro de la definición establecida por el inciso 1 del artículo 13 de la ley peruana que regula el arbitraje. (Barchi, 2013)

De lo explicado, precedentemente, se puede precisar que el convenio arbitral es el consenso de voluntades de las partes o decisión de un tercero, a través del cual se decidirá someter determinadas controversias que puedan surgir o hayan tenido lugar, respecto de ciertas relaciones jurídicas. Esto último significa que se puede acordar llevar a cabo un proceso arbitral ya sea antes o después del conflicto. Cabe resaltar, que solo puede someterse a arbitraje aquellos conflictos que sean objeto de libre disposición, si así lo señala la ley, de acuerdo a lo establecido por el artículo 2 de la ley peruana de arbitraje.

\section{Extensión del Convenio Arbitral.}

Por otro lado, en relación a la extensión del convenio arbitral el artículo 14 del Decreto Legislativo $\mathrm{N}^{\circ} 1071$ establece lo siguiente:

El convenio arbitral se extiende a aquellos cuyo consentimiento de someterse a arbitraje, según la buena fe, se determina por su participación activa y de manera 
determinante en la negociación, celebración, ejecución o terminación del contrato que comprende el convenio arbitral o al que el convenio esté relacionado. Se extiende también a quienes pretendan derivar derechos o beneficios del contrato, según sus términos. (Congreso de la República del Perú, 2008)

De la lectura del citado dispositivo legal, se advierte que hay quienes a pesar de no haber suscrito un documento que contenga el convenio arbitral, son partes del mismo. Ello en virtud de la posibilidad de la multiplicidad de partes involucradas en una 0 varias relaciones jurídicas. Como señala Bullard, la ley de arbitraje buscó figuras procesales que se desarrollaban en la jurisprudencia resolviendo este problema. La intención de la ley no es incorporar terceros al arbitraje. (Soto, 2011) De lo contrario, si se excluye a los terceros involucrados pero no signatarios, puede ir perdiendo efectividad - y por tanto utilidad - como medio de resolución de conflictos, donde las controversias nacen dentro de una red entrelazada de relaciones directas e indirectas. (De Trazegenis, 2004, pág. 21)

Cabe señalar que existen los siguientes requisitos para determinar quiénes son partes no signatarias:

El primero de ellos es el que ha tenido participación activa, a la luz de un criterio de buena fe. Esta participación debe haber sido: (i) activa y (ii) determinante en las distintas etapas del contrato que comprende el convenio arbitral o al convenio vinculado. La segunda clase abarca a aquellos sujetos que buscan derivar derechos o beneficios del contrato, según las estipulaciones del mismo. (Repetto, Hundskopf, \& Valderrama, 2014, pág. 212)

Alfredo Bullard, nuevamente sobre el particular indica que existen excepciones a la obligación de suscripción del convenio arbitral, a quienes podemos denominar partes no signatarias, en los siguientes supuestos: incorporación por referencia, representación y agencia, stoppel o doctrina de actos propios, levantamiento de velo societario, contrato a favor de tercero, acción oblicua, cesión, novación y subrogación. (Soto, 2011)

\section{Forma del Convenio Arbitral.}

La ley que regula el arbitraje, Decreto Legislativo $\mathrm{N} \cong 1071$, a través del artículo 13 regula la forma del convenio arbitral estableciendo que éste debe constar por escrito (numeral 2), y brinda que alcance tiene el requisito "por escrito" precisando que en los siguientes casos se entenderá que el convenio tiene tal forma: 
a) Cuando haya constancia de contenido en cualquier forma, incluso cuando el mismo se haya concertado a través de la ejecución de actos o cualquier otro medio,

b) Cuando exista comunicación electrónica y que dicha información consignada sea accesible para su ulterior consulta,

c) Cuando en el intercambio de los escritos de demanda y contestación, en el que la existencia del convenio sea afirmada por una parte, sin que ello sea negado por la otra, $y$

d) La referencia en un contrato a un documento que contenga una cláusula de arbitraje, siempre que esa referencia implique que la cláusula de arbitraje forma parte del contrato. (Congreso de la República del Perú, 2008)

Cabe resaltar que si bien la ley de arbitraje especifica la forma del convenio arbitral, no sanciona con nulidad su inobservancia, lo cual si ocurría con la ley anterior de 1996. En consecuencia, "se ha abandonado la exigencia de una formalidad solemne (escrito) para la celebración del convenio arbitral y ha optado por una formalidad ad probationem". (Soto, 2011, pág. 168)

\section{Principio de Separabilidad del Convenio Arbitral.}

Sobre el origen histórico de este principio, Caivano expone:

La cláusula compromisoria había sido históricamente tratada como un pacto accesorio de aquel, y consecuentemente, alcanzada por las vicisitudes que afecten al contrato en el que se incluye. A la luz de las concepciones tradicionales, la cláusula arbitral, en tanto pacto accesorio, quedaba atada a la existencia y eficacia de la convención principal, de tal forma que la inexistencia o la ineficacia de esta última traían aparejada la del acuerdo arbitral. Sin embargo, la práctica demostró que la inconveniencia de este razonamiento. La consecuencia de adoptar este criterio era que los árbitros nunca podrían entender en una controversia en la que se discutiera, precisamente, la existencia, subsistencia o validez del contrato del cual surgía la controversia, ya que el solo cuestionamiento de alguna de las partes llevaba a los árbitros a resignar su jurisdicción a la espera de una decisión judicial sobre esas cuestiones. (Caivano R. , 2015, pág. 20)

Antes del establecimiento del principio de separabilidad del convenio arbitral, cualquier cuestionamiento al contrato que contiene el convenio afecta también a este último, como consecuencia de su accesoriedad. En consecuencia, el convenio arbitral era ineficaz. 
Como señala Roger Rubio, este principio supone que el convenio arbitral "es independiente y autónomo del contrato principal y de cualquier vicio que lo afecte, de manera que el cuestionamiento de la validez o existencia del contrato principal no produce un efecto inmediato sobre la validez o existencia del convenio arbitral". (Rubio, 2010 / 2011, pág. 101)

Asimismo, Bullard explica que en virtud de este principio se deja atrás la concepción sobre el carácter accesorio del convenio arbitral del contrato principal, y como consecuencia de ello, en caso se verifique la nulidad de éste último, el convenio arbitral también devenga en nulo. (Bullard, 2012, pág. 23)

Sobre la finalidad de este principio señala Caivano:

El propósito general que anima este principio es evitar que una de las partes, arrepintiéndose del arbitraje pactado por no convenir a su estrategia de defensa, pueda manipular la situación para entorpecer el arbitraje y llevar a sede judicial la determinación de las cuestiones controvertidas que había acordado a someter a arbitraje, eludiendo la común intención de prescindir de la intervención de los tribunales estatales. (Caivano R. , 2015, pág. 23)

En ese sentido, el principio de separabilidad o de autonomía del convenio arbitral establece la independencia de éste respecto del contrato del cual pueden surgir controversias que se pretenden resolver a través de arbitraje y como resultado de ello, en el supuesto exista algún defecto del contrato, del cual tienen virtud las relaciones jurídicas que sean objeto de arbitraje, el convenio arbitral no sufrirá los efectos de los defectos del contrato.

Competencia del Tribunal Arbitral.

El Tribunal Constitucional mediante la sentencia $\mathrm{N}^{\circ}$ 6167-2005-PHC/TC, conocido como el caso "Cantuarias Salaverry", señala en su fundamento 14: "Este Tribunal reconoce la jurisdicción del arbitraje y su plena y absoluta competencia para conocer y resolver las controversias sometidas al fuero arbitral, sobre materias de carácter disponible". (Tribunal Constitucional, 2006)

Como señala el Tribunal Constitucional, de acuerdo a lo expresado por la Constitución Política del Perú, los tribunales arbitrales tienen la facultad de administrar justicia, es decir resolver controversias sometidas al fuero arbitral, siempre que los mismos sean de carácter disponible, sin la intervención de autoridad judicial ni administrativa. 
Asimismo, el artículo $40^{\circ}$ del Decreto Legislativo $N^{\circ} 1071$, señala que el tribunal arbitral es competente para conocer el fondo de la controversia y para decidir sobre conflictos relacionados al mismo, así como para dictar las reglas complementarias para la adecuada conducción y desarrollo de las mismas.

En ese sentido, los tribunales arbitrales tienen potestad de resolver determinados conflictos, siempre que las partes así lo hayan convenido y que se traten de derechos disponibles.

Sin perjuicio de lo señalado, es conveniente indicar que se debe aplicar el principio favor arbitri, cuando exista conflicto en relación a las controversias que deben ser resultas a través de arbitraje. Como señala Soto Coaguila, haciendo referencia a Luciano Barchi:

En el caso de una relación jurídica de fuente contractual, si el convenio no es claro, de acuerdo con el principio favor arbitri que consagra la nueva LA, deberán considerarse "todas" las controversias derivadas de la relación jurídica contractual, lo cual debe comprender, incluso, las cuestiones extracontractuales derivadas de dicha relación jurídica contractual. (Soto, 2011, pág. 167)

\section{Arbitrabilidad.}

Habiendo explicado sobre la competencia del tribunal arbitral, es pertinente exponer que es la arbitrabilidad. Al respecto, Caivano señala que "la arbitrabilidad es una cualidad de lo que es arbitrable, lo que significa "que es susceptible de ser arbitrado", término aplicable a las materias (arbitrabilidad objetiva) y a las personas (arbitrabilidad subjetiva)" (Caivano J. , 2013, pág. 64)

Respecto a la arbitrabilidad objetiva, las materias que son susceptibles a arbitraje pueden ser aquellos de libre disposición de las partes y en sentido contrario, no se pueden resolver conflictos a través de arbitraje aquellas cuestiones que interesan al orden público, como lo son los delitos, las faltas, etc. (Cantuarias, 1994, pág. 137)

Y sobre la arbitrabilidad subjetiva, quienes celebren un convenio arbitral, si son personas naturales, deben tener capacidad de ejercicio, es decir deben haber cumplido los 18 años de edad, y carecer de incapacidad absoluta o relativa, sin embargo, estos últimos pueden suscribir el convenio a través de sus representantes legales. En el caso sean personas jurídicas los celebrantes, lo pueden suscribir a través de sus representantes, quienes deberán estar facultados debidamente para ello. 
Principio de Competence - Competence.

Este principio, en sus origines de la escuela alemana manifestaba que solo el árbitro debe decidir sobre su propia competencia, sin embargo, tal razonamiento ha cambiado gracias a la escuela francesa, que señala que si bien el árbitro resuelve sobre su propia competencia, la decisión que se tome al respecto será revisada por un juez. (Gonzáles, 2006).

Sin embargo, hoy mayoritariamente es aceptado que hay un doble control de la competencia de los árbitros, por lo que para explicar el mismo, se ha desarrollado la teoría de los dos disparos, "el primer disparo (first shot) — para conocer la validez del convenio arbitral— le corresponde al árbitro; mientras que el segundo disparo (second shot), al juez" (Córdova, 2015, pág. 291)

De acuerdo con Alfredo Bullard, "El principio kompetenz-kompetenz, según el cual los árbitros son competentes para resolver cualquier cuestionamiento a su propia competencia, resuelve un círculo vicioso cuya resolución es esencial para permitir la auto ejecución" (Bullard, 2012, pág. 22)

Roger Rubio agrega que este principio tiene dos efectos: positivo y negativo. El primero hace referencia a los supuestos que establece el artículo 40.1 del Decreto Legislativo $\mathrm{N}^{\circ}$ 1071: inexistencia, nulidad, anulabilidad, invalidez 0 ineficacia del convenio arbitral, materia no sometida a arbitraje y cualesquier otra que impida al tribunal arbitral de conocer el fondo de la controversia. El segundo se encuentra regulado en el artículo $16^{\circ}$ de la mencionada ley, este dispositivo señala dos momentos: i) el proceso arbitral no ha iniciado, y en vista de tal situación se interpone una demanda judicial, cuyo hecho puede ser invocado como excepción del convenio arbitral, salvo que éste fuese manifiestamente nulo y ii) si el arbitraje ha iniciado, habiéndose acreditado la existencia del convenio arbitral, se debe amparar la pretensión de excepción del convenio arbitral y remitir las partes al proceso arbitral. (Rubio, 2010 / 2011)

Es pertinente indicar que usualmente se afirma que este principio necesita al de independencia del convenio arbitral, dado que, de lo contrario, este no sería eficaz. Como indicant Lew, Mistelis \& Kröll: "Without the doctrine of separability, a tribunal making use of its competence - competence would potentially be obliged to deny jurisdiction on the merits since the existence of the arbitration clause might be affected by the invalidity of the underlying contract" [Sin la doctrina de la separabilidad, un tribunal haciendo uso de competence - competence estaría potencialmente obligado a 
declinar de su competencia sobre el fondo dado que la existencia de la cláusula arbitral podría verse afectada por la invalidez del contrato subyacente] (Lew, Mistelis, \& Kröll, 2003, pág. 334)

En consecuencia de lo expuesto, en virtud del principio competence - competence el tribunal arbitral puede resolver los conflictos relativos a su propia competencia, ello con la finalidad de prevenir que una de las partes obstaculice el arbitraje y que esta controversia se resuelve en los tribunales estatales, hecho que pretende retardar dilucidar el conflicto principal.

El árbitro de emergencia.

La primera vez que se reguló sobre el árbitro de emergencia, fue a través del Reglamento del Procedimiento Pre Arbitral de la CCl del año 1990, en el cual se desarrolla el procedimiento que se debe seguir con el objetivo de adoptar medidas cautelares de manera breve, en comparación del tiempo que pueda tomar si es solicitada ante el juez. (Vega, 2017)

Actualmente, la labor del árbitro de emergencia en el arbitraje peruano es dirigir el procedimiento a través del cual se aceptará o no la solicitud cautelar cuando la constitución del tribunal arbitral no haya tenido lugar (las llamadas medidas cautelares antes del proceso), en lugar requerirlo ante un juez.

Cabe resaltar que la ley peruana de arbitraje no ha dispuesto sobre el particular. Lo que señala la ley literalmente es que en el supuesto exista la necesidad de solicitar una medida cautelar sin que el tribunal arbitral se haya constituido, ella se debe solicitar ante una autoridad judicial, sin embargo, en los Reglamentos de la Cámara de Comercio de Lima y Centro de Análisis y Resolución de Conflictos PUCP si se ha previsto esta figura, ello con la finalidad de que se otorgue la medida de forma célere.

La medida cautelar.

En relación a la medida cautelar, Hurtado Reyes señala: "No solo son instrumentos para defender los derechos subjetivos, si no que sirven para garantizar la eficacia, en tanto a la seriedad de la función jurisdiccional”. (Hurtado, 2006, págs. 182-183)

De igual manera, Nuria Mallandrich, señala que las medidas cautelares constituyen un mecanismo dirigido a mitigar los efectos del tiempo en el proceso, permitiendo asegurar que cuando finalmente se dicte la resolución sobre el fondo del asunto, esta pueda llegar a ser eficaz. (Mallandrich, 2010) 
En ese orden de ideas, Proto Pisani señala sobre la tutela cautelar tiene las siguientes finalidades: "Neutralizar los efectos en virtud de la duración del proceso, reforzar la actuación del derecho independientemente de la duración del proceso de cognición, reforzar los efectos sustanciales de la demanda o por la existencia de títulos ejecutivos". (Proto, 2018, pág. 639)

De todo lo expuesto, se tiene que, la medida cautelar es una institución jurídica que tiene por finalidad asegurar la tutela del fondo, dado que, de esperar hasta la emisión de la decisión final sobre el conflicto, este sería ineficaz, por el tiempo que pueda tomar el proceso. De esta manera, se aminora los daños que pueda ocasionar al solicitante de la medida cautelar hasta que se resuelva el conflicto.

Presupuestos de la solicitud cautelar.

Verosimilitud del derecho.

Sobre este presupuesto, Giovanni Priori señala lo siguiente:

No es un juicio emitido al azar ni sobre las bases de intuiciones del juzgador, sino que, es un juicio que sin llegar a basarse en la certeza, es pasible de ser corroborado con los medios de prueba que se han ofrecido en el pedido cautelar. (Priori, 2006, pág. 74)

En ese orden de ideas, Monroy Palacios explica que la verosimilitud no tiene por objeto que el juez evalúe la fundabilidad de la pretensión, sino que esta tenga sustento jurídico. Por lo que, en otras palabras, lo que se requiere es que el derecho alegado tenga apariencia de existencia para obtener una medida cautelar. (Monroy, 2002)

Peligro en la demora.

Sobre este supuesto Piero Calamandrei expone lo siguiente:

El periculum in mora que constituye la base de las medidas cautelares no es, pues, el peligro genérico del daño jurídico, al cual se puede, en ciertos casos, obviar con tutela ordinaria; si no que es específicamente, el peligro ulterior daño marginal derivar el retardo de la providencia definitiva, inevitable a causa de la lentitud del procedimiento ordinario. (Calamandrei, 2005, pág. 42)

Priori Posada enfatiza que el peligro en la demora se configura por dos caracteres: “a) El riesgo del daño jurídico debe ser provocado por la demora del proceso y b) el daño debe ser eminente, justificando así la necesidad de otorga una medida cautelar." (Priori, 2006, págs. 38-39) 
Es pertinente resaltar que este presupuesto es el más importante, dado que la medida cautelar tiene por propósito proteger que la sentencia sea eficaz, ante el daño que pueda ocasionar la demora del proceso. En ese sentido, al no existir un peligro que pueda convertir en irreparable el derecho, la medida cautelar no tendría razón de ser.

\section{Razonabilidad de la medida.}

Las medidas cautelares son otorgadas con la finalidad de evitar ocasionar perjuicio por el tiempo que pueda el proceso tomar, de lo contrario la decisión final podría ser ineficaz. En ese sentido, el juez debe otorgar la medida cautelar más razonable para alcanzar tal objetivo, en palabras de Monroy Palacios: "se debe otorgar aquella medida que afecte lo menos posible los intereses del sujeto sobre quien recae la misma, se trata del principio de mínima injerencia” (Monroy, 2002, pág. 188). Enfatizando además el autor en ese orden de ideas, que las medidas cautelares deben ser otorgadas de manera congruente y proporcional.

\section{Medidas cautelares en arbitraje.}

Las medidas cautelares en arbitraje, al igual que en el proceso llevado acabo ante un juez pueden ser solicitadas antes de iniciar el proceso (en arbitraje, la ley denomina este momento antes de la constitución arbitral) y durante el proceso.

En el primer supuesto, de acuerdo al Decreto Legislativo 1071 se solicita ante el juez competente, sin embargo como se ha mencionado previamente, en los Reglamentos de la Cámara de Comercio de Lima y Centro de Análisis y Resolución de Conflictos de PUCP se ha previsto que éstas puedan ser solicitadas ante el árbitro de emergencia.

Cuando la medida cautelar es otorgada antes del proceso, el solicitante debe iniciar el arbitraje dentro de 10 días siguientes de ejecutada la medida cautelar. De no realizarse de tal manera e incluso de haberse cumplido con ello, no se constituyera el tribunal arbitral dentro de 90 días de ordenada, ésta caduca de pleno derecho, de acuerdo con el numeral 4 del artículo 47 de la ley de arbitraje. (Congreso de la República del Perú, 2008).

En relación a las medidas cautelares otorgadas durante el proceso, estas deben ser solicitadas cuando el tribunal arbitral este constituido, conforme lo señala el numeral 1 del artículo $47^{\circ}$ del mencionado cuerpo legal. 
Cabe resaltar que las medidas cautelares otorgadas por el juez (antes del proceso), el proceso llevado a cabo para determinar si es concedido o no es inaudita pars, es decir, solo quien solicita la medida cautelar es partícipe de este proceso, sin la contradicción de quien ejecutará la medida cautelar. Al contrario, cuando las medidas cautelares son solicitadas durante el proceso arbitral, las partes del proceso "principal" tienen conocimiento y participan en el proceso cautelar, salvo que el solicitante solicite y justifique que el proceso cautelar sea inaudita pars, para garantizar la eficacia de la misma.

Responsabilidad por el daño por la ejecución de las medidas cautelares.

El profesor uruguayo Garderes expone:

De modo que, el "el daño injusto" sería, desde ese punto de vista, el resultante de la ejecución de una medida cautelar dejada posteriormente sin efecto por la falta de mérito (en lo principal o en la incidencia cautelar). El análisis del instituto cautelar se traslada de esa forma, a la perspectiva del cautelado, es decir, el sujeto gravado o afectado por la ejecución de una medida cautelar. (Garderes, 2003, pág. 23)

En relación a la naturaleza de esta responsabilidad Ledesma señala que, "esta surge por la ejecución del mandado cautelar y constituye un caso de responsabilidad extracontractual nacida exclusivamente en el ámbito procesal y que asegura, por medio de la contractual". (Ledesma, 2013, pág. 59)

\section{Elementos de la responsabilidad civil.}

Previamente a explicar sobre los daños ocasionados por la ejecución de las medidas cautelares es pertinente señalar como se determina la responsabilidad civil en este caso. Campos García señala que debe tener en consideración los elementos generales de responsabilidad civil: "daño, acto generador de responsabilidad, relación de causalidad y criterio de imputación, pero, claro está, con sus respectivos requisitos y peculiaridades". (Campos H. A., 2013, pág. 763)

Asimismo, de acuerdo con lo expuesto por el profesor Gastón Fernández Cruz, existe un método que contiene dos etapas para determinar este tipo de responsabilidad:

i. Una primera de análisis material, en donde revisándose los elementos del daño, (su vinculación con) el hecho generador, (a través de) la relación de causalidad, se logra identificar al "causante" del efecto dañoso; (Polacco, 1898, pág. 251) 
ii. Una segunda (y tal vez la más importante) en donde a través del juicio de imputabilidad (que es en sí el juicio de responsabilidad), se decidirá que es más eficiente (y justo a nivel social): si dejar que la víctima soporte el coste del daño o traspasar este peso económico hacia una esfera ajena a la víctima, sea al propio causante (dando lugar a la responsabilidad por hecho propio), o sea a un tercero no causante pero "justamente" vinculado (dando lugar a la responsabilidad por hecho ajeno). Esto se realiza a través de la aplicación de alguno de los criterios de imputación, sean estos de naturaleza subjetiva u objetiva. (Polacco, 1898, págs. 251-252)

El daño.

En palabras del profesor Gastón Fernández: "El daño es el menoscabo o lesión que sufre un individuo, persona o ente en su integridad o en su patrimonio, así como en sus derechos de personalidad" (Fernandez, 2019, pág. 63)

Siguiendo la línea de razonamiento del profesor Fernández Cruz, los requisitos del daño resarcible son los siguientes:

\section{Certeza.}

Este requisito está comprendido por dos elementos: factico y lógico. El primero se refiere a que el daño se haya producido en la realidad y el segundo como comprobación de relación de causalidad entre el hecho y la consecuencia (daño) (Fernandez, 2019)

\section{Subsistencia del daño.}

Los hermanos Mezeud señalan sobre este elemento:

Claro está que, cuando el autor del daño es el que ha reparado por sí mismo, el problema considerado no se plantea: es cierto que la víctima no le puede ya reclamar nada. Sucede así, evidentemente, cuando ha sido dispuesto por una sentencia, la excepción de cosa juzgada se opondría a cualquier demanda nueva que se refiera al mismo perjuicio. (Mazeud \& Mazeud, 1957, pág. 330)

En ese sentido este elemento hace referencia a que no haya sido reparado el daño con anterioridad. Sin embargo, el profesor Fernández Cruz señala que cabe la posibilidad de solicitar nuevamente la indemnización por daños en la "vía civil" a pesar de haberse obtenido una reparación en la "vía penal", de acuerdo a la casación Nº 2092-2016. (Fernandez, 2019) 


\section{Especialidad del daño.}

Este requisito implica "identificar el interés tutelado afectado por el daño, así como el sujeto que es tutelar" (Fernandez, 2019, pág. 75). Cabe señalar que es posible el reconocimiento de una pluralidad de hechos generadores del daño, a lo que se denomina concausa (Fernandez, 2019)

La injusticia del daño.

Para que se resarza el daño es necesario que estos no sean daños justamente sufridos, es decir que no deban ser soportados por la víctima. (Fernandez, 2019). Son daños injustamente sufridos, aquellos que el ordenamiento jurídico no lo califican como son supuestos de irresponsabilidad civil: el ejercicio regular del derecho, legítima defensa y estado de necesidad, supuestos establecidos en el artículo 1971 del Codigo Civil.

El hecho generador del daño.

Este elemento no tiene una connotación jurídica, es un evento factico que se vincula con el daño causado con la víctima. (Fernandez, 2019). Resaltamos sobre este elemento que no es necesaria su vinculación con un hecho ilícito dado que nuestro ordenamiento jurídico ha abandonado la categoría del hecho ilícito.

Relación de causalidad.

Tradicionalmente, se define a este elemento como "la razón para que una determinada persona y no otra sea obligada a pagar; una razón que individualice un presunto responsable dentro del universo de personas". (De Trazegnies, 1988, pág. 281) El autor resalta además que el análisis causal se basa en la voluntad de la ley, la cual responde a propósitos sociales y no en la orden natural (relación causaefecto). (De Trazegnies, 1988)

Sin embargo, también se afirma que "este es el elemento que va a permitir identificar el verdadero hecho generador del daño, dado que al ser la vida una concatenación de hechos y circunstancias, nunca se presenta la realidad de un mero hecho aislado" (Fernandez, 2019, pág. 55)

Cabe señalar que existen fracturas causales, las cuales de presentarse, no se genera responsabilidad civil a un tercero. Estas son: caso fortuito, fuerza mayor y hecho determinante de la víctima.

Factor de atribución. 
A este criterio se le define como "la razón suficiente por la cual se justifica que el daño ha sufrido una persona se traslade económica a otra" (Ghersi, Stiglitz, \& Parellada, 1997, pág. 141).

Espinoza define este elemento como aquel que contesta la pregunta: " ¿a título de que se es responsable? Vale decir, constituye el fundamento de indemnizar" (Espinoza, 2013, pág. 183)

En ese mismo orden de idas, Fernández Cruz expone que el factor de atribución "es el justificativo teórico del traspaso del peso económico del daño de la víctima al responsable". (Fernandez, 2019, pág. 143)

Existen dos tipos de criterios: subjetivo, dentro del cual se encuentra el dolo y culpa, y objetivo.

Factores de atribución subjetivos.

En relación a la culpa, Espinoza señala que esta debe ser entendida como una ruptura o contravención a un estándar de conducta. (Espinoza, 2013).

Haciendo un análisis sobre tal definición de culpa, Trigo Represas afirma la existencia de dos tipos de culpa: negligencia, en el cual un sujeto omite un acto que hubiese evitado el resultado dañoso, "hace menos de lo que se debe" e imprudencia, en el cual un sujeto obra sin prever las consecuencias que ocasionará su acción, "hace más de lo que debe" (Trigo, 1978, págs. 25-26 )

Por otro lado, el dolo, consiste en la voluntad y conciencia de hacer daño. Existen 3 acepciones del dolo:

i) Como vicio de la voluntad, en donde el dolo es entendido como ardid o engaño del que se vale un sujeto para celebrar un negocio jurídico. Como vicio del consentimiento, el dolo dará lugar a la anulación del acto celebrado;

ii) Como deliberado propósito de incumplir una obligación asumida, que caracterizará el denominado "dolo contractual"; siendo los tipos de dolo hasta aquí mencionados, los dos sentidos respecto a los cuales se habla en las obligaciones derivadas de los contratos; $y$,

iii) Como deliberado propósito de causar daño, que configurará el denominado "animus nocend" y que caracterizará tanto al dolo penal como al dolo extracontractual. (Polacco, 1898, págs. 235-236) 
Factor de atribución objetivo.

Espinoza denomina a este factor, como aquel que "se basa en factores de atribución objetivos, considerados como tales por el ordenamiento jurídico". (Espinoza, 2013, pág. 207) De igual manera, como señala Orteaga Piana, se asocia a este con "situaciones legalmente previstas en las que se ha determinado que un tercero asuma la obligación legal de indemnizar pese a que no ha tenido incidencia o participación fáctica o presencial en el evento dañoso" (Orteaga, 2011, pág. 62)

Cabe señalar que existe conflicto en relación al juicio de imputación para la determinación de responsabilidad por el daño provocado por la ejecución de medidas cautelares.

Por un lado, se sostiene que la responsabilidad derivada de la ejecución de una medida cautelar es meramente "objetiva", argumentando ello por el mero hecho de la derrota, es decir, que no se haya declarado a favor de la parte demandante, sin ser relevante la existencia o no de culpa, dolo o mala fe procesal. (Ledesma, 2013)

Frente a este criterio se ha señalado, que de delimitarse así el criterio de imputación, "se ordenaría el pago de una indemnización a quien actuó en ejercicio regular de un derecho; esto es, al demandante que actuó en ejercicio regular de su derecho a la tutela cautelar". (Zavaleta, 2012)

Frente a tales premisas, Campos García expone que como en cualquier otro caso de responsabilidad, cabe la posibilidad que coexistan escenarios de responsabilidad subjetiva y objetiva, en concreto. De lo contario, se generaría contradicciones y patologías. (Campos H. A., 2013)

Cabe resaltar que en relación a que la responsabilidad en ese tipo de caso, sea consecuencia del ejercicio regular de un derecho, el autor antes citado argumenta:

Efectivamente, la idea de total irresponsabilidad, respecto de los daños que se generen como consecuencia del ejercicio regular de un derecho, colisiona frontalmente contra la idea de la relatividad de los derechos, esto es, con la realidad de que los derechos, inclusive de carácter constitucional, no son absolutos, si no que admiten limitaciones intrínsecas y extrínsecas, en función de su relación con otros derechos. Así, lo primero que debe establecerse para entender la función de la cláusula normativa general del ejercicio regular de un derecho, es precisamente, que todo ejercicio de un derecho presenta limitaciones, 
las cuales pueden ser agrupadas en dos grandes figuras: el abuso del derecho y la colisión de derechos. (Campos H. , 2012, págs. 221-222)

Como se puede verificar de lo descrito, la delimitación de la responsabilidad civil, en particular por la ejecución de medidas cautelares requiere un arduo análisis por parte del juzgador, quien según nuestro objeto de estudio es el tribunal arbitral.

Ahora bien, teniendo en consideración que elementos deben coexistir para la configuración de la responsabilidad civil, debemos señalar para que se determine la indemnización por los daños ocasionados por la ejecución de medida cautelar en caso esta no debió haberse otorgado, quien sea responsable de decidir al respecto, en este caso el tribunal arbitral, debe revisar si los elementos expuestos tienen lugar antes de requerir al solicitante de la medida cautelar el pago de una indemnización por la ejecución de la misma.

La contracautela.

La contracautela tiene por finalidad de resarcir los posibles daños que ocasione la ejecución de la medida cautelar y con el propósito de dilucidar a mayor detalle esta figura, la desarrollaremos a continuación:

Como lo señala Ledesma, la contracautela tiene como objetivo el equilibrio procesal. Por un lado, pretende neutralizar el posible daño que la realización de la ejecución de la medida cautelar pueda acarrear a la parte contraria, y por otro, evitar poner en condiciones de inferioridad a esa parte. (Ledesma, 2013)

Sobre éste, Héctor Campos expone seis características de la contracautela:

a) es un mecanismo de garantía, dado que implica el compromiso de determinado patrimonio o bienes con la finalidad de asegurar la obligación garantizada, b) la contracautela se decreta en el marco de un proceso pero se manifiesta a través de la constitución de una garantía real o personal, que son de naturaleza material, c) es un requisito de validez de la resolución cautelar que concede la solitud y de eficacia de la resolución cautelar, d) la obligación garantizable consiste en aquella derivada de la actuación de cautelar que hacia el final del proceso se demuestra sin fundamento, e) la obligación resarcitoria es de carácter eventual dado que no es hecho cierto que se haya surgido la responsabilidad civil al momento del ofrecimiento de la contracautela y f) la obligación resarcitoria es determinable ya que la obligación garantizada no se encuentra plenamente identificada al momento del ofrecimiento, sin embargo, es susceptible a ser determinada cuando 
se verifique la responsabilidad civil del solicitante. (Campos H. , 2015, págs. 187188)

Teniendo en consideración lo señalado, la caución o contracautela tiene por finalidad garantizar el resarcimiento por el posible daño que pueda ocasionar la ejecución de una medida cautelar, así como que es de carácter procesal, requisito de validez y eficacia de la resolución cautelar, etc.

\section{Tipos de Contracautela.}

El artículo 613 del Código Procesal Civil señala que hay dos tipos de contracautela: la real y personal. En relación a la contracautela de carácter real, se puede expresar en una suma de dinero, títulos o bienes que pueden pertenecer al propio beneficiado o incluso a terceros, quienes darán su conformidad para ofrecerlos como garantía en beneficio del afectado con la medida cautelar.

Por otro lado, la contracautela personal se expresa en la fianza. Es la garantía procesal que presta un tercero de reconocida solvencia de responder por los presuntos daños que pudiesen sobrevenir al cautelado. Se contempla también, como garantía personal al juramento del propio afectado o promesa de terceros, de reconocida solvencia económica, de responder por el posible perjuicio que pudiera producir la ejecución cautelar. (Ledesma, 2013, págs. 121-122)

¿Cuál es el procedimiento para el otorgamiento de la indemnización por daños que ocasione la ejecución de una medida cautelar en el arbitraje comercial domestico peruano?

Recordemos que el inciso 8 del artículo 47 del Decreto Legislativo 1071 establece que el tribunal arbitral puede solicitar el pago por el daño que ocasione la ejecución de una medida cautelar a quien la requirió, cuando se determine que ésta no debió haberse otorgado. Sin embargo, no brinda un procedimiento para delimitar este tipo de responsabilidad.

De igual manera, los reglamentos de los principales centros de arbitraje no brindan mayor detalle al respecto, se limitan a parafrasear el citado dispositivo legal:

Por ejemplo, la Cámara de Comercio de Lima establece en el artículo 34.5 de su reglamento: 
La parte que solicite una medida cautelar es la única responsable de los costos y de los daños y perjuicios que dicha medida ocasione a cualquier parte. El tribunal arbitral puede resolver sobre estos temas y sobre la ejecución de las garantías de cualquier medida cautelar. (Cámara de Comercio de Lima, 2017, pág. 41)

Asimismo, el artículo 69 del reglamento de arbitraje del Centro de Análisis y Resolución de Conflictos PUCP:

Las partes serán responsables de los costos y de los daños y perjuicios que la ejecución de las medidas cautelares solicitas le ocasione a la contraparte, siempre que los árbitros consideren que dadas las circunstancias del caso no debió haberse otorgado la medida. En este caso, los árbitros pueden condenar al solicitante en cualquier momento del proceso, el pago de los costos y de los daños y perjuicios. (Centro de Análisis y Resolución de Conflictos PUCP, 2017, pág. 26)

Y por último, el artículo 37.4 del reglamento del Centro de Arbitraje de Amcham:

El solicitante de una medida cautelar es responsable de los costos y de los daños y perjuicios que dicha medida ocasione a alguna de las partes, siempre que el tribunal determine ulteriormente que en las circunstancias del caso, no debía otorgar la medida. En ese caso, el tribunal puede condenar al solicitante, en cualquier momento de las actuaciones, el pago de los costos y de los daños y perjuicios. (Cámara de Comercio Americana del Perú, 2013, pág. 27)

Como se puede verificar, el Decreto Legislativo N 1071 y los reglamentos de los principales centros de arbitraje no señalan los criterios para determinar la responsabilidad por el posible perjuicio que pueda provocar la ejecución de una medida cautelar, ni un procedimiento para lograr el mismo. Siendo ello así, cabe preguntar como el tribunal podrá lograr condenar el pago por este daño.

A diferencia de lo que sucede en la ley de arbitraje, el Código Procesal Civil brinda un "procedimiento" para determinar este tipo de responsabilidad, en el artículo 621, estableciendo que el juez advertirá la indemnización previo traslado por tres días.

Cabe señalar que el Proyecto de Reforma del Código Procesal Civil, a través del artículo 638 establece un procedimiento para resolver este conflicto:

El pedido de indemnización se tramita en el mismo cuaderno en el que se tramitó la medida provisional. El afectado con la medida debe precisar la cuantía del daño 
y adjuntar a su pedido los medios probatorios pertinentes. El juez corre traslado del pedido al beneficiado con la medida provisional por un plazo de seis días y, con su absolución o sin ella, resuelve. El monto indemnizatorio dispuesto por el juez debe justificarse en los medios probatorios ofrecidos. Cuando por la naturaleza del daño no pueda establecerse de manera precisa el monto indemnizatorio, el juez podrá establecerlo en base a un criterio equitativo. La resolución que se pronuncia sobre el pedido de indemnización es apelable sin efecto suspensivo. Contra la resolución que resuelve el pedido en segunda instancia no cabe recurso de casación. (Grupo de trabajo encargado de revisar y proponer mejoras al Código Procesal Civil, 2018)

De igual manera, el profesor Campos ha propuesto lo siguiente, en relación a este conflicto en procesos llevados a cabo ante el Poder Judicial:

El pedido de indemnización se tramita en el mismo cuaderno en el que se tramitó la medida provisional. El afectado con la medida debe precisar la cuantía del daño y adjuntar a su pedido los medios probatorios pertinentes. El juez corre traslado del pedido al beneficiado con la medida provisional por un plazo de seis días y, con su absolución o sin ella, resuelve.

El monto indemnizatorio dispuesto por el juez debe justificarse en los medios probatorios ofrecidos. Cuando por la naturaleza del daño, sea material o moral, no pueda establecerse de manera precisa el monto indemnizatorio, el juez podrá establecerlo en base a un criterio equitativo.

La resolución que se pronuncia sobre el pedido de indemnización es apelable sin efecto suspensivo. Contra la resolución que resuelve el pedido en segunda instancia no cabe recurso de casación. (Campos H. , 2018, pág. 294)

Por otro lado, en el ordenamiento jurídico suizo, encontramos que también el tribunal arbitral también tiene competencia para resolver el conflicto por perjuicio ocasionado por la ejecución de medidas cautelares en el numeral 4 del artículo 374 del Código de Procedimiento Civil Suizo, en la sección que regula el arbitraje doméstico:

The applicant is liable for the harm caused by unjustified interim measures. If he or she proves, however, that the application for the measures was made in good faith, the arbitral tribunal or the ordinary court may reduce the damages or relieve the applicant entirely from liability. The aggrieved party may assert his or her claim in the pending arbitration. [El solicitante de una medida cautelar es responsable 
por los daños que hayan provocado cuando son injustificadas, sin embargo, si la solicitud fue realizada de buena fe, el tribunal puede reducir los daños o liberarlo de responsabilidad. La parte perjudicada puede hacer valer su reclamo en el arbitraje pendiente.] (Asamblea Federal Suiza, 2008)

Cabe destacar que dentro de esta pregunta, surge también la siguiente interrogante: ¿Cuándo se podría solicitar la indemnización por los daños provocados por la ejecución de un laudo o resolución que conceda una medida cautelar, o que acto provoca este daño?

El profesor Podetti señala sobre este tema:

Resumiendo y sistematizando los supuestos de responsabilidad y conforme con lo expuesto precedentemente, el hecho constitutivo de la responsabilidad - haber pedido la medida cautelar sin derecho - puede derivar del instrumento usado (el proceso) o de la pretensión deducida en justicia (el derecho subjetivo invocado) Puede derivar del mismo proceso, es decir, formalmente considerando: a) si se desiste la medida; b) si queda sin efecto por no iniciarse el proceso definitivo; c) si la medida se revoca por la inexistencia de alguno de los presupuestos específicos; d) si se deja sin efecto por resultar luego ineficaz la prueba de dichos presupuestos. (...) Puede derivar de la pretensión: a) si se desiste de la demanda principal (desistimiento de la acción o de la instancia, en este último caso si no se inicia la nueva demanda), b) si la demanda principal es desestimada por inexistencia del derecho pretendido o de legitimación sustancial activa y pasiva; c) si producida la caducidad de las instancias no se inició la nueva demanda (como en el caso de desistimiento de instancia, sin iniciar nuevo proceso se presume la inexistencia del derecho que no se cautelo; d) si se rechaza la demanda por prosperar la excepción dilatoria y no se modifica o inicia nuevamente la demanda. (Podetti, 1956, págs. 132-133)

En la ley de enjuiciamiento civil de España se ha establecido en sus artículos 742 y 745 que después de la revocación de la medida cautelar, como consecuencia de la solicitud de oposición del otorgamiento de la medida cautelar, sentencia absolutoria, renuncia de la acción o desistimiento de la instancia el juez debe condenar los daños y perjuicios ocasionados. (Las Cortes Generales, 2000)

Eduardo Couture también propuso sobre este asunto lo siguiente en su Proyecto de Código de Procedimiento Civil de 1945: 
Cuando se mande a levantar una medida de garantía, ya sea porque se ha obtenido indebidamente, ya sea porque el embargado resulta absuelto de la demanda principal, o por cualquier otro motivo, se establecerá en el mismo fallo, que el que ha solicitado la medida deberá pagar los daños y perjuicios que tal medida hubiere causado. (Couture, 1945)

En nuestro país, se prevé que se puede determinar esta responsabilidad al declararse infundada la demanda. Ello conforme a lo dispuesto por el código procesal civil vigente.

Habiéndose solo señalado un solo escenario, se ha propuesto en el proyecto de ley $\mathrm{N}^{\circ}$ 2377-2012-CR que se deba incluir las formas de conclusión del proceso con y sin declaración del fondo del proceso con excepción del inciso 7 del artículo 321 e incisos 2 y 3 del artículo 322, la cual no fue fructífera.

Posteriormente, en el Proyecto de Reforma del Código Procesal Civil se sugiere que debe incluirse los supuestos de conclusión del proceso con y sin declaración del fondo y aquellos actos que motivan el levantamiento de la medida cautelar.

Dado que este último es el más completo, porque incluye más escenarios, es el que analizaremos posteriormente.

¿Cómo se interpretan las disposiciones legales?

Para empezar, necesitamos conocer que entendemos por disposición y norma. En palabras de Riccardo Guastini, el primero es un "enunciado que forma parte de un documento normativo, es decir a cada enunciado del discurso de fuentes". Y al segundo, como "aquel que constituye el significado atribuido a una disposición" (Guastini R. , 2011, pág. 136)

El mismo autor en otra obra señala:

Mientras que la disposición constituye el objeto de la actividad interpretativa, norma constituye su resultado. La disposición es un enunciado del lenguaje de las fuentes sujeto a interpretación y pendiente de ser interpretada. En cambio, la norma es una disposición interpretada y, de esta forma, reformulada por el intérprete; esta es, por tanto un enunciado del lenguaje de los intérpretes. (Guastini R. , 2016, págs. 74-75)

Giovani Tarello agrega, que la actividad interpretativa no implica descubrir un significado, lo cual es abiertamente aceptado, si no, por el contrario, "el intérprete 
detecta, decide o propone el significado de uno o más enunciados perceptivos detectando, decidiendo o proponiendo que el derecho ha incluido, incluye o incluirá una norma”. (Tarello, 2018, pág. 102)

Cabe señalar que el autor expone diferentes perfiles de interpretación, sin embargo, concluye que éste siempre se atañe a la atribución de significados a textos normativos. (Guastini R. , 2011). En ese mismo orden de ideas, Giovanni Tarello manifiesta que la labor de la atribución de significados a las disposiciones legales (documentos que expresan las normas reguladoras de la vida social) se ejercen a través del control sobre los procedimientos intelectuales que llevan a cabo la decisión y los argumentos que sostienen la misma. (Tarello, 2018)

Esta manera de diferenciar disposiciones legales y normas, ha sido reconocida por el Tribunal Constitucional a través de la sentencia del expediente N 010-2002-Al/TC, fundamento 34 :

En ese sentido, se debe subrayar que en todo precepto legal se puede distinguir: a) El texto o enunciado, es decir, el conjunto de palabras que integran un determinado precepto legal (disposición); b) El contenido normativo, o sea el significado o sentido de ella (norma). (Tribunal Constitucional, 2003)

En esta cita, el Tribunal Constitucional distingue lo señalado de acuerdo a lo indicado también por Riccardo Guastini.

Al ser la norma la atribución de sentido de una disposición legal, existen diferentes métodos para llegar a ella:

Método literal.

También denominado sentido común de las palabras por Riccardo Guastini, a través del cual las normas se desprenden de la gramática y del diccionario. (Guastini R. , 2018).

Sobre este método, el autor enfatiza que es inestable dado que cabe la posibilidad de que el sentido común de una disposición cambie del momento en el que fue promulgada y el de su aplicación. En ese sentido, distingue dos métodos literales:

La interpretación "originalista" y la "evolutiva". La primera atribuye a las palabras el sentido que tenían en el momento de la formulación del texto. La segunda elige el significado que ellas adquieren en el momento de su aplicación. (Guastini R. , 2018, pág. 271) 


\section{Método histórico.}

Este método también es denominado "intención del legislador". Sobre el particular Cossio expone, "debe ser entendida como una intención histórica y no como intención personal, es decir, busca la significación que efectivamente correspondió a la ley en su origen en base de las circunstancias históricas que determinaron la intención como fenómeno de conciencia" (Cossio, 1940, pág. 27)

\section{Método teleológico.}

El método teleológico, conocido también como ratio legis. Método mediante que lograremos atribuir sentido a una disposición legal, de acuerdo a la finalidad de la misma, su razón de ser.

Este método ha sido utilizado para resolver controversias, como aquel que recae en la sentencia del expediente $\mathrm{N} \cong 4677-2004-\mathrm{PA} / \mathrm{TC}$ :

Sin embargo, este Colegiado aprecia, tras una interpretación teleológica del aludido artículo $200^{\circ} 2$ de la Carta Fundamental, que esta disposición tiene por propósito evitar que el proceso constitucional de amparo se convierta en una vía en la que pueda enjuiciarse, en abstracto, la validez constitucional de la generalidad de las normas (no sólo las legales), con el propósito de, determinada su inconstitucionalidad, expulsarlas del ordenamiento jurídico, pues dicho cometido ha sido reservado constitucionalmente al proceso de inconstitucionalidad (artículo $200^{\circ} 4$ ) -en lo que a las normas de rango legal respecta-, y al proceso de acción popular (artículo 2005) -en lo que a las normas de rango infra legal se refiere. (Tribunal Constitucional, 2005)

\section{Método sociológico.}

Como señala Guastini, la elección del intérprete respecto de diferentes normas que se desprenden de un dispositivo legal, se fundamenta en exigencias sociales. "No hace falta decir que la identificación de las "exigencias sociales" — lo que la sociedad requiere - no es y no puede ser el resultado de una averiguación empírica; es más bien el resultado de una valoración política del intérprete" (Guastini R. , 2018, pág. 273)

El Tribunal Constitucional Peruano sobre este método ha señalado

Por su parte, la interpretación social permite maximizar la eficiencia de los derechos económicos, sociales y culturales en los hechos concretos, de modo tal 
que las normas programáticas, en cuya concreción reside la clave del bien común, no aparezcan como una mera declaración de buenas intenciones, sino como un compromiso con la sociedad dotado de metas claras y realistas. (Tribunal Constitucional Peruano, 2003)

\section{Método sistemático.}

Este tipo de argumento sirve para preservar, a la vez, la consistencia lógica y la coherencia (la armonía) axiológica del derecho. (Guastini R. , 2018, pág. 273)

Este método ha sido utilizado en reiteradas oportunidades por el Tribunal Constitucional, como por ejemplo para dilucidar la controversia que obra en el expediente №6612-2005-PA/TC:

Dicha garantía institucional se infiere de una interpretación sistemática de los artículos $10^{\circ}$ y $11^{\circ}$ de la Constitución. Así, el derecho a la seguridad social se instituye como una garantía institucional del derecho a la pensión, al posibilitar su vigencia según los parámetros correspondientes a un Estado social y democrático de Derecho. De esta forma, la seguridad social está prevista en la Constitución como la garantía institucional del derecho a la pensión. (Tribunal Constitucional Peruano, 2007)

Es basta la utilización de los métodos de interpretación a través de la jurisprudencia para dilucidar conflictos, como a través del expediente № 0001-2004-CC/TC:

El Tribunal Constitucional no comparte la opinión de la demandante, pues considera que existen diversos criterios de interpretación que permiten sostener que la competencia especial asignada a la MML (...):

\section{a. Interpretación literal}

En primer término, una interpretación literal del inciso 1.3) del artículo $161^{\circ}$ de la LOM, esto es, una identificación del contenido normativo a partir de lo que el propio enunciado lingüístico transmite, permite sostener que la competencia en materia de constitución, organización y administración del sistema metropolitano de parques y, consecuentemente, de los parques que lo integran - entre los que se encuentran los parques zonales -, corresponde a la MML y no a los municipios distritales.

b. Interpretación teleológica 
Los parques zonales pueden ser definidos como áreas importantes de recreación pública cuya función y equipamiento están destinados a servir a la población con servicios de recreación activa y pasiva. Al igual que los parques zoológicos, los beneficios que otorga un parque zonal no se agotan en la comunidad vecinal de un distrito, sino que su radio de destinatarios y potenciales usuarios es per se indeterminado. En tal sentido, los servicios recreacionales que provee son bastante más ambiciosos que los de los denominados parques locales. Por ello, aplicando una interpretación teleológica del inciso 1.3) del artículo $161^{\circ}$ de la LOM, mal podría considerarse que su administración debe permanecer en el control de un nivel distrital, siendo lo razonable atribuirla al nivel provincial. (...)

c. Interpretación histórica

Para determinar si, de acuerdo a una interpretación histórica del precepto, el legislador ha pretendido asignar una competencia exclusiva a la MML en la administración de los parques zonales de la provincia de Lima, es necesario introducir algunas consideraciones sobre cuál ha sido el régimen de gestión al que históricamente se han encontrado sometidos los parques zonales en la capital de la República. (Tribunal Constitucional, 2004) 


\section{Objetivos e Hipótesis}

\section{Objetivos.}

\section{Objetivo General.}

Analizar las posibles interpretaciones sobre la facultad del tribunal arbitral de requerir el pago de los daños ocasionados por la ejecución de una medida cautelar, establecida así en el inciso 8 del artículo 47 de la ley peruana de arbitraje.

Objetivos Específicos.

1. Revisar si la discusión sobre la responsabilidad por el perjuicio que ocasione la ejecución de una medida cautelar en el proceso arbitral excede o no de lo pactado al celebrarse el convenio arbitral.

2. Analizar si la indemnización por los daños ocasionados en virtud de la ejecución de una medida cautelar es otorgada a solicitud de parte o de oficio.

3. Descubrir cuál sería el procedimiento y las particularidades procesales para la discusión respecto el daño que pueda provocar la ejecución de una medida cautelar en arbitraje.

\section{Hipótesis.}

\section{General.}

Los tribunales arbitrales están facultados de requerir el resarcimiento por el daño que ocasione la ejecución de la medida cautelar al someterse a la ley peruana de arbitraje, Decreto Legislativo 1071.

Específicos.

1. El debate sobre la responsabilidad por el perjuicio que ocasione la ejecución de una medida cautelar en el proceso arbitral no excede de lo pactado al celebrar el convenio arbitral.

2. El otorgamiento de indemnización por los daños ocasionados en virtud de la ejecución de la medida cautelar debe ser solicitada a pedido de parte.

3. La ley peruana no establece un procedimiento para la discusión sobre los daños que ocasione la ejecución de una medida cautelar, sin embargo, ello no significa que este conflicto no sea resuelto. Por lo que, el tribunal arbitral debe dirigir el 
procedimiento, según las particularidades del caso, dando oportunidad a las partes de pronunciarse sobre la cuantificación del daño, presentar pruebas, entre otros. Sin perjuicio de ello, propondremos un procedimiento en el capítulo de recomendaciones. 


\section{Método}

\section{Tipo y diseño de la investigación}

\section{Tipo de investigación.}

De acuerdo con el nivel de complejidad de estudio, el presente trabajo será de carácter descriptivo, dado que, éste nos permitirá investigar las características y particularidades de la presente investigación. Por otro lado, según al tipo de análisis que se someterá la información recolectada, el presente trabajo será de tipo cualitativo, debido a "que se enfoca en comprender los fenómenos, explorándolos desde la perspectiva de los participantes en un ambiente natural y en relación con su contexto" (Hernández, 2014, pág. 358)

Al tener como objetivo el presente trabajo, analizar respecto a un problema inmerso en la práctica jurídica, en específico la facultad de los tribunales arbitrales de condenar el resarcimiento por el daño que ocasione la ejecución de la medida cautelar, cuando el tribunal arbitral considere que esta no debió haberse otorgado, lo señalado será lo más idóneo dado que ayudará a analizar y descubrir respecto nuestro planteamiento del problema, sin intervenir directamente, logrando así llegar a conclusiones concretas.

\section{Diseño de investigación}

El diseño de investigación del presente trabajo, de acuerdo al tipo de análisis cualitativo, será de teoría fundamentada, en particular, el teórico, por lo que seguiremos con las siguientes acciones:

En primer lugar, propondremos el planteamiento del problema, mediante el cual describiremos la situación problemática que consiste en que la actual ley de arbitraje otorga la competencia al tribunal arbitral de determinar el pago por el posible perjuicio que ocasione la ejecución de una medida cautelar.

Cabe aquí resaltar sobre la recolección de datos, la cual se realizará antes y durante todo el proceso de investigación del presente trabajo. Ello nos ayudará a determinar la formulación del problema, los objetivos, la hipótesis, la justificación, así como delimitar e ilustrar las categorías y sus respectivas características del marco referencial. Luego de ello, agruparemos las categorías en temas y las relacionaremos entre sí. 


\section{Instrumentos de investigación.}

Los instrumentos de investigación que nos ayudará a obtener información respecto a nuestro objeto de estudio, serán de carácter documental, en específico, libros y revistas de autores nacionales e internacionales, así como entrevistas.

\section{Procedimientos.}

Habiendo indicado que como instrumentos de investigación utilizaremos libros y revistas, es pertinente precisar que obtendremos información de tales objetos, acudiendo a diferentes bibliotecas de la ciudad, como la Biblioteca Nacional, Biblioteca de la Universidad Mayor de San Marcos, Biblioteca de la Universidad San Ignacio de Loyola, así como de la plataforma Vlex, cuya licencia es otorgada por nuestra casa de estudios, repositorio PUCP, y demás herramientas tecnológicas.

Emplearemos distintos métodos de estudio como, resúmenes, apuntes de información relevante, agrupándola por temas y subtemas respectivamente.

\section{Plan de análisis.}

La presente investigación al ser de análisis cualitativo, seguiremos con los siguientes pasos:

1) explorar los datos, 2) imponerles una estructura (organizándolos en unidades y categorías), 3) descubrir las experiencias de los participantes según su óptica, lenguaje y expresiones, 4) descubrir los conceptos, categorías, temas y patrones presentes en los datos, así como sus vínculos, a fin de otorgarles sentido, interpretarlos y explicarlos en función del planteamiento del problema, 5) comprender en profundidad el contexto que rodea los datos, 6) reconstruir hechos e historias, 7) vincular los resultados con el conocimiento disponible y 8) generar una teoría fundamentada en los datos. (Hernández, 2014, pág. 418) 


\section{Resultados}

\section{Discusión}

Habiendo investigado y analizado la teoría en relación a nuestro objeto de investigación y enfrentado con este último, corresponde ahora desarrollar los problemas señalados en el capítulo de formulación del problema, enfrentar los posibles resultados y elegir el más adecuado para este estudio.

\section{La discusión sobre la responsabilidad por el perjuicio que ocasione la ejecución de una medida cautelar ¿excede de lo pactado por las partes al celebrar un convenio arbitral que señala que aquellas controversias que deriven de determinada relación jurídica se resolverán a través de arbitraje?}

Del estudio y análisis de la presente investigación, se obtuvo que la mencionada discusión no excede de lo pactado en el convenio arbitral, por las siguientes consideraciones:

En primer lugar, quienes celebran un convenio arbitral eligiendo a la ley peruana como derecho aplicable, se someten voluntariamente a lo que el ordenamiento jurídico peruano establece.

En ese sentido, al señalar la ley que regula el arbitraje, Decreto Legislativo 1071 a través del artículo 2, que las materias susceptibles de arbitraje son aquellas de libre disposición y los que la ley señale, son las partes quienes manifestaron su voluntad de que la ley peruana determine que controversias se dilucidarán a través de arbitraje además de lo que específicamente determinaron en el convenio arbitral.

En consecuencia de tal exposición, al indicar nuevamente la ley peruana que el tribunal arbitral puede condenar la indemnización por ejecución de medidas cautelares, articulo 47, no excede de lo establecido en el convenio arbitral. Ello en virtud del sometimiento libre a las disposiciones del ordenamiento jurídico peruano.

Por otro lado, de afirmarse que no cabe la posibilidad de que los árbitros resuelvan sobre este conflicto porque el mismo deriva de una relación jurídica extracontractual, es decir de una relación distinta a la del contrato del cual se decidió que cuyas controversias deriven de él se resolverán a través de arbitraje, recordemos el principio a favor arbitri. Este último establece que se debe inclinar por aquellas interpretaciones que favorezcan que un conflicto se resuelva a través de arbitraje como lo es el de la presente investigación, el cual tuvo lugar como consecuencia de un acto llevado a 
cabo en el proceso arbitral, de lo contrario este conflicto se resolvería en las cortes ordinarias, consecuencia que las partes desearon evitar. En ese orden de ideas, el tribunal arbitral también puede conocer el conflicto ocasionado por el daño en virtud de la ejecución de una resolución cautelar en el arbitraje comercial domestico peruano.

En segundo lugar, consideremos los posibles efectos de indicar que los tribunales arbitrales no deban dilucidar el conflicto planteado. De aceptar ello, quienes tengan el conflicto originado por el daño de la ejecución de una medida cautelar en arbitraje, deberían celebrar nuevamente un convenio arbitral e iniciar nuevamente un arbitraje, de lo contrario, acudir al Poder Judicial para dilucidar el mismo.

Si se estima el primer escenario, se debe evaluar la disponibilidad de las partes para celebrar nuevamente un convenio arbitral, costo y tiempo adicional en el que se incurriría para llevar a cabo el arbitraje. En el segundo, no está demás indicar la demora que implicaría resolver el conflicto debido a la gran cantidad de procesos que se llevan a cabo en el Poder Judicial. De acuerdo al informe emitido por el Sistema Integrado de Justicia actualmente existen 1097129 procesos en trámite, de acuerdo al siguiente detalle:

\begin{tabular}{|c|c|c|c|c|c|}
\hline & & & & \multicolumn{2}{|c|}{ Actualizado al 22/10/2019 } \\
\hline \multirow{3}{*}{ Especialidad } & \multicolumn{3}{|c|}{ Procesos Pendientes } & \multicolumn{2}{|c|}{ Variación 2019/18 } \\
\hline & 2017 & 2018 & 2019 & Diferencia & $\%$ \\
\hline & (A) & (B) & (C) & $(\mathrm{D})=(\mathrm{C})-(\mathrm{B})$ & $(\mathrm{E})=(\mathrm{D} / \mathrm{B}) \%$ \\
\hline Civil & 261572 & 292385 & 294627 & 2242 & $0.8 \%$ \\
\hline Familia & 252056 & 268084 & 259459 & -8625 & $-3.2 \%$ \\
\hline Laboral & 216242 & 245962 & 246214 & 252 & $0.1 \%$ \\
\hline Penal & 266168 & 279497 & 296829 & 17332 & $6.2 \%$ \\
\hline Total & 996038 & 1085928 & 1097129 & 11201 & $1.0 \%$ \\
\hline Plazo de Impugnación & 415508 & 566314 & 665052 & & \\
\hline $\begin{array}{l}\text { Fuente: Sistema Integrad } \\
\text { Elaboración: Sub Geren } \\
\text { Nota: Información actuali }\end{array}$ & $\begin{array}{l}\text { ial - For } \\
\text { Estadistic } \\
22 \text { de } 0\end{array}$ & $\begin{array}{l}\text { o Estadis } \\
\text { erencia d } \\
2019\end{array}$ & $\begin{array}{l}\text { Electrónico } \\
\text { lanificación }\end{array}$ & & \\
\hline
\end{tabular}

llustración 1: Procesos en trámite en el Poder Judicial Peruano

Fuente: Poder Judicial, 2019

Además, cabe indicar que hay una tendencia de crecimiento de las demandas ingresadas por año: 

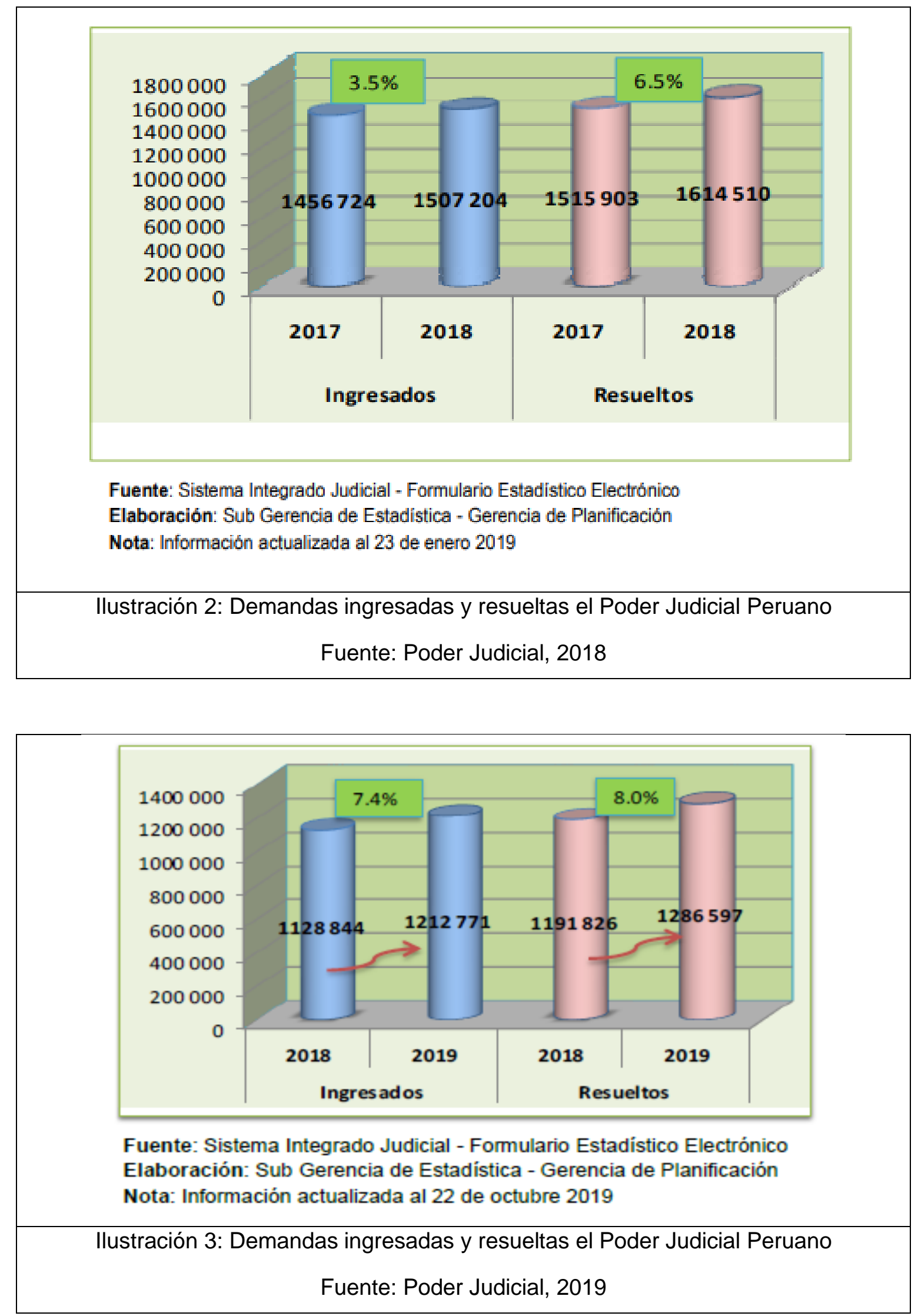
En ese sentido, trasladar este conflicto al tribunal estatal vulneraria lo deseado por las partes al celebrar el convenio arbitral, resolver un conflicto de manera rápida y eficiente.

Por el contrario, si se resuelve la controversia objeto de la presente investigación, junto a aquella que se determinó en el convenio arbitral, las partes no tendrían por qué iniciar otro proceso para resolver el mismo. En consecuencia, no hay costo extra en relación a tiempo (disposición de las partes para celebrar otro convenio arbitral, instalación del tribunal arbitral, etc.) ni en dinero (costo adicional por pago de honorarios a abogados y árbitros, etc.)

En ese sentido, se verifica que hay mayor beneficio para las partes de un proceso arbitral interpretar que el conflicto originado por el daño ocasionado por la ejecución de una medida cautelar no excede de lo establecido en el convenio arbitral, y en consecuencia, deba dilucidarse con aquel que si se "determinó" en el convenio arbitral.

\section{¿Cómo es otorgada la indemnización por los daños ocasionados en virtud de la ejecución de una medida cautelar?}

Nuevamente el dispositivo legal en cuestión, solo señala que el tribunal "puede" resolver este conflicto, sin señalar si es a pedido de oficio o de parte. Al tener ambas posibilidades de interpretación, analicemos ambos escenarios:

De considerarse que la indemnización por el daño ocasionado en virtud de la ejecución de una resolución cautelar es otorgada de oficio, surgen las siguientes preguntas: ¿Cómo podría el árbitro determinar la existencia del daño, cuantificar el mismo, la relación de causalidad, sin conocer la posición de la parte perjudicada? ¿No es la parte perjudicada quien mejor puede describir el daño que se le ocasionó? ¿No debe existir un proceso previo que permita a la parte que ocasionó el daño exponer y cuestionar sobre el daño originado?

Efectivamente, el tribunal tiene competencia para resolver respecto si se debe otorgar o no la indemnización por el daño ocasionado por la ejecución de una resolución cautelar, sin embargo, no se puede realizar de oficio, dado que es la parte afectada quien debe alegar el daño y establecer el monto equivalente para reparar el mismo, el cual puede ser igual, mayor o igual al de la contracautela ofrecida, señalando además la relación de causalidad entre el acto generador de responsabilidad (daño -evento) y el daño ocasionado (daño - consecuencia) y demás factores. 
Es la propia parte afectada quien mejor puede describir el perjuicio que se la ha ocasionado, dado que de realizarlo un tercero, no podrá identificar de la misma manera el mismo, más aun si el daño es no patrimonial.

Por último, consideramos que la indemnización debe ser a solicitud de parte, con la finalidad que exista un procedimiento a través del cual se le dé la oportunidad a la parte afectada de expresar el daño ocasionado y por qué se le debe indemnizar, y a quien realizó el daño para que pueda allanarse o cuestionar la solicitud. Y solo después de ello, el tribunal analice si se debe otorgar o no lo solicitado ya sea en su totalidad o en parte, garantizando de esta manera el derecho al debido proceso de las partes, entendido este como una visión dinámica del derecho a la tutela jurisdiccional efectiva. (Monroy, 2017)

Sin perjuicio de lo señalado, si las partes acuerdan resolver conforme crean conveniente respecto este conflicto, deben informar al tribunal sobre esa decisión con la finalidad de que el mismo sea plasmado en el laudo, como lo indica el artículo 50 de la ley que regula el arbitraje.

\section{¿Cuál es el procedimiento y las particularidades procesales para la discusión} sobre los perjuicios de la ejecución de una medida cautelar en el arbitraje?

Consideremos pertinente previamente a señalar un procedimiento en si respecto a este conflicto, que se debe indicar cuando es el momento más oportuno para determinar la responsabilidad por la ejecución de una medida cautelar en arbitraje. La ley que regula el arbitraje se limita a indicar como "cuando el tribunal considere que la medida cautelar no debió haberse otorgado". En ese sentido, expondremos cuando debe tener lugar este momento.

Actualmente, el Código Procesal Civil señala sobre este conflicto que la indemnización será otorgada cuando la demanda sea declara infundada. Sin embargo, cabe preguntar si ese debe ser el único supuesto de responsabilidad. Al respecto la profesora Eugenia Ariano ha realizado algunas críticas sobre el particular en su artículo "Tutela cautelar y statu quo en la reforma procesal (Comentarios a una propuesta de modificación que poco pretende modificar)", en el cual expone que si bien se ha propuesto en el Proyecto de Ley № 2377-2012-CR incluir más supuestos en los que luego de ocurridos, formas de conclusión del proceso "principal", se debe incluir más escenarios como aquellos que provocan el levantamiento de la medida cautelar. 
Frente a tal situación, habiendo realizado un análisis al respecto, se ha propuesto en el artículo 637 del Proyecto de Reforma del Código Procesal Civil, que la responsabilidad se determinará cuando exista una resolución firme que disponga la conclusión del proceso sin y con declaración sobre el fondo, establecidos en los artículos 321 y 322 respectivamente del mencionado Proyecto, así como en los casos previstos en los incisos 1 al 4 del artículo 635, escenarios que provocan el levantamiento de la medida cautelar. (Grupo de trabajo encargado de revisar y proponer mejoras al Código Procesal Civil, 2018)

Consideramos que podemos denominar a las formas de conclusión del proceso y actos que provocan el levantamiento de la medida cautelar como "supuestos que determinan que la medida cautelar no debió haberse otorgado". A su vez podemos denominar a los actos que provocan el levantamiento de la medida cautelar de configuración simple y compleja a las formas de conclusión del proceso. "Será un acto simple cuando sea relevante el destino del propio proceso cautelar y complejo cuando además de la procedencia de la medida cautelar en proceso respectivo, dependa el resultado final en el proceso de fondo" (Campos H. , 2015, pág. 165)

Es pertinente indicar que tomamos como referencia lo señalado en el Código Procesal Civil y el Proyecto de Reforma dado que ambos tienen como objetivo regular los procesos llevados a cabo ante una autoridad judicial, la cual es una forma de resolución de conflictos, igual que el arbitraje. Por otro lado, resaltamos que en el Proyecto de Reforma del Código Procesal Civil se pretende regular respecto a la responsabilidad de una medida previsional, el cual comprende la tutela cautelar y medida anticipada. En ese sentido, al estar comprendido la tutela cautelar, la cual forma parte de nuestro objeto de estudio, es factible incluir la propuesta en el análisis de la presente investigación.

Habiendo señalado los "supuestos que determinan que la medida cautelar no debió haberse otorgado" por la ejecución de una medida cautelar expuestos en el Proyecto de Reforma, debemos analizar cuales si deben considerados para el objeto de la presente investigación y si hay otros que no lo están que si deben ser incluidos como actos generadores de responsabilidad en la presente investigación.

Análisis de los supuestos que determinan que la medida cautelar no debió haberse otorgado respecto de aquellos actos que provocan el levantamiento de la medida cautelar. 
De acuerdo al Proyecto de Reforma de Código Procesal Civil estos supuestos están comprendidos en los artículos 1 al 4 del artículo 635.

Supuestos que no determinan que la medida cautelar no debió haberse otorgado.

a. El acto contenido en el inciso 1:

Cuando se omite presentar la demanda dentro del plazo de 10 días hábiles luego de ejecutada la medida cautelar fuera del proceso o en los 20 días luego de notificada su concesión. (Grupo de trabajo encargado de revisar y proponer mejoras al Código Procesal Civil, 2018)

Una disposición equivalente a esta en arbitraje es la indicada en el inciso 4 del artículo 47:

Las medidas cautelares solicitadas a una autoridad judicial antes de la constitución del tribunal arbitral no son incompatibles con el arbitraje ni consideradas como una renuncia a él. Ejecutada la medida, la parte beneficiada deberá iniciar el arbitraje dentro de los diez (10) días siguientes, si no lo hubiere hecho con anterioridad. Si no lo hace dentro de este plazo o habiendo cumplido con hacerlo, no se constituye el tribunal arbitral dentro de los noventa (90) días de dictada la medida, ésta caduca de pleno derecho. (Congreso de la República del Perú, 2008)

Sobre este supuesto en particular, resaltamos si debería ser incluido como un supuesto de configuración compleja, dado que la medida cautelar quedaría sin efecto a consecuencia de un acto que no se produjo en el proceso principal, el no inicio del proceso arbitral y la no constitución del tribunal arbitral dentro de los plazos establecidos. Sin perjuicio de ello, de producirse el mismo, el tribunal arbitral no podría resolver respecto de los daños ocasionados por la ejecución de la resolución cautelar dado que no se inició el proceso y/o no está constituido el tribunal.

No obstante, si existe un proceso arbitral en el cual se discuta un conflicto relacionado al conflicto anterior que motivó la solicitud cautelar "que no debió haberse otorgado" por la no constitución o inicio del proceso se puede solicitar a este "nuevo tribunal" la indemnización por los daños ocasionados que provocaron la ejecución de una medida cautelar, en virtud del artículo 40 de la ley de arbitraje. En el supuesto no se inicie un "nuevo proceso", se debe solicitar al juez esta indemnización, dado que este tiene competencia sobre todos los aspectos en 
torno a ella hasta que el tribunal se constituya, de acuerdo con el inciso 5 del artículo 47 de la ley de arbitraje.

Supuestos que determinan que la medida cautelar no debió haberse otorgado.

a. Cuando se dispone el levantamiento o revocación de la medida provisional por parte del juez superior. (Grupo de trabajo encargado de revisar y proponer mejoras al Código Procesal Civil, 2018)

b. El siguiente supuesto no está incluido en el Proyecto de Reforma, sin embargo, dado que es un supuesto exclusivo en los procesos arbitrales:

El tribunal arbitral está facultado para modificar, sustituir y dejar sin efecto las medidas cautelares que haya dictado así como las medidas cautelares dictadas por una autoridad judicial, incluso cuando se trate de decisiones judiciales firmes. Esta decisión podrá ser adoptada por el tribunal arbitral, ya sea a iniciativa de alguna de las partes 0 , en circunstancias excepcionales, por iniciativa propia, previa notificación a ellas. (Congreso de la República del Perú, 2008)

Ambas situaciones si determinan cuando la medida cautelar no debió haberse otorgado dado que ambos supuestos un tercero, quien no dictó la medida cautelar, con competencia para pronunciarse al respecto, establece que la medida cautelar se deje sin efecto, en el primer supuesto lo realiza un juez y en el segundo el tribunal arbitral. Dichas situaciones evidenciarían que se está perjudicando a quien soportó los efectos de la medida cautelar dado que luego de su revisión se verificó que no debió haberse otorgado.

c. El acto contenido en el inciso 2:

Cuando en cualquier estado del proceso se declara la improcedencia de la demanda o se dispone la conclusión del proceso por abandono o cualquier otra forma de conclusión del proceso sin declaración sobre el fondo. (...) (Grupo de trabajo encargado de revisar y proponer mejoras al Código Procesal Civil, 2018)

El abandono del proceso tiene lugar por inactividad procesal y el interesado, es decir, el demandante debe promover que se lleven a cabo las acciones pertinentes para la emisión del laudo, de lo contrario, podríamos afirmar que realmente no 
existe la urgencia para obtener lo que se pretendía en el proceso. Y ante la inexistencia de urgencia por el tiempo que puede tomar el proceso principal, se perjudica a quien ejecutó la resolución cautelar dado que este sigue soportando medidas que fueron concedidas con la finalidad de asegurar que la decisión final sea ineficaz para el demandante por el transcurso del tiempo.

Cabe señalar que, actualmente no hay plazo señalado en la ley que regula de arbitraje ni en los reglamentos de los principales centros de arbitraje, sin embargo, si existe en caso de regulación al respecto cuando el Estado Peruano es parte del proceso, disposición incorporada a la ley de arbitraje a través del Decreto de Urgencia 20-2020.

Ante tal situación coincidimos con el profesor Guillermo Lohmann Luca en incluir esta institución en la ley:

La LGA carece de norma al respecto, que se echa muy de menos. Bien es cierto que el Código Procesal Civil estatuye en su Primera Disposición Fiscal que sus normas se aplican supletoriamente a los demás ordenamientos procesales que sean compatibles con la naturaleza del proceso civil, pero atendiendo a lo dispuesto en el artículo IV del Código Civil (<<La ley que establece que excepciones o restringe derechos no se aplica por analogía >>) puede surgir la duda de si siendo el abandono una suerte de sanción cabe aplicarla en sede arbitral. Personalmente considero que sí, porque no es sensato que la parte negligente tenga constreñidos a los árbitros y a la otra parte y sujetos a una relación procesal en la que se ha perdido interés. (Lohmann, 2005, pág. 217)

Sin perjuicio de ello, consideramos que el tribunal arbitral podrá declarar el abandono del proceso a pesar de no estar regulado en la ley de arbitraje, en virtud de su libertad de regulación de las actuaciones.

d. El acto contenido en el inciso 3:

Cuando se dicta una sentencia, en primera o segunda instancia, que declara infundada o improcedente la demanda que sirve de sustento a la medida provisional. (Grupo de trabajo encargado de revisar y proponer mejoras al Código Procesal Civil, 2018)

Este escenario también motivaría a que la medida cautelar no debió haberse otorgado dado que el laudo que se pronuncia sobre la pretensión que se aspiraba 
proteger (por ser potencialmente ineficaz por el transcurso del tiempo desde la presentación de la demanda hasta la emisión del laudo) fue declarada infundada.

Análisis de los supuestos que determinan que la medida cautelar no debió haberse otorgado respecto de aquellos actos que provocan la conclusión del proceso.

Lo que se propone en el Proyecto de Reforma del Código Procesal Civil, es incluir en esta categoría las formas de conclusión del proceso. Sin embargo, dadas las diferencias que existen entre el proceso arbitral y civil no deben ser incluidas todas directamente como actos generadores de responsabilidad para el presente estudio.

La ley que regula el arbitraje, Decreto Legislativo 1071 no establece las formas de conclusión del proceso, no obstante, los reglamentos de arbitraje de las principales Centros de Arbitraje, señalan una forma de conclusión de diferente a la emisión del laudo:

Artículo 87: En los casos de conclusión anticipada del arbitraje, como son el desistimiento, conciliación, entre otros, así como en los supuestos de archivo, en los que corresponda, la Corte de Arbitraje se pronunciará sobre la devolución de los honorarios profesionales, a pedido de una de las partes. (Centro de Análisis y Resolución de Conflictos PUCP, 2017)

Artículo 38: i) Si antes de que se dicte un laudo que ponga término al arbitraje, las partes llegan a un acuerdo sobre la materia controvertida y solicitan al Tribunal Arbitral que deje constancia de dicho acuerdo en un laudo, el Tribunal Arbitral lo dicta sin necesidad de motivarlo, salvo que lo estime apropiado. En los demás casos, el Tribunal Arbitral ordena la terminación de las actuaciones. El arbitraje continúa en relación con las cuestiones que no sean materia del acuerdo de las partes. ii) Si antes de que se dicte un laudo que ponga término al arbitraje, cualquiera de las partes retira su demanda o su reconvención por cualquier otro motivo, el Tribunal Arbitral ordena la terminación de las actuaciones respectivas, salvo que la otra parte, por razones justificadas, solicite un pronunciamiento de los árbitros. (Cámara de Comercio de Lima, 2017)

Artículo 56: Cuando el tribunal arbitral ordene la terminación de las actuaciones arbitrales por transacción, conciliación o por cualquier otra razón, la Corte determina el importe de los gastos arbitrales. (Cámara de Comercio Americana del Perú, 2013) 
Como se verifica, los reglamentos indicados solo señalan supuestos de conclusión, diferente al laudo, al desistimiento, conciliación, transacción o cualquier otro, por lo que consideramos pertinente nuevamente recurrir a lo que también establece el Código Procesal, siempre que se adecuen a la naturaleza del proceso arbitral.

Los supuestos de conclusión del proceso en el Proyecto de Reforma y en el Código Procesal son idénticos, salvo que en el primero se incluyó la declaración de caducidad del juez dentro de la clasificación de formas de conclusión del proceso con declaración sobre el fondo, y en el segundo como una forma de conclusión del proceso sin declaración sobre el fondo.

Supuestos que no determinan que la medida cautelar se haya otorgado de acuerdo a la propuesta de formas de conclusión del proceso sin declaración del fondo.

a. Artículo 321.- Conclusión del proceso sin declaración sobre el fondo. Concluye el proceso sin declaración sobre el fondo cuando: 1 . Se sustrae la pretensión del ámbito jurisdiccional. (Grupo de trabajo encargado de revisar y proponer mejoras al Código Procesal Civil, 2018)

Se presentaría una "sustracción de materia" de un proceso pendiente cuando por hechos sobrevenidos al planteamiento de la demanda (en rigor, a la notificación de la demanda) el actor obtiene extraprocesalmente lo que pretendía o cuando lo que pretendía ha devenido ya imposible de obtener. (Ariano, 2012, pág. 146)

En relación al primer factor podemos ejemplificarlo como una transacción o conciliación respecto de la controversia, los cuales son formas "independientes" de conclusión de proceso, que revisaremos más adelante.

El segundo es un motivo por el cual la medida cautelar debe dejar de tener efectos, sin embargo no se podría exigir la indemnización responsabilidad civil del solicitante de la medida cautelar por el daño soportado dado que la medida cautelar otorgada con la finalidad de que el laudo sea eficaz no seguirá cumpliendo tal función al ser la pretensión (que podría haber sido declarada fundada) imposible de obtener, siempre que ello sea a consecuencia de alguna de las partes del proceso.

b. Artículo 321.- Conclusión del proceso sin declaración sobre el fondo. Concluye el proceso sin declaración sobre el fondo cuando: 2. Por disposición legal, el conflicto de intereses deja de ser un caso justiciable. (Grupo de trabajo encargado de revisar y proponer mejoras al Código Procesal Civil, 2018) 
De igual manera, este supuesto debe ser una razón por la cual se levante la medida cautelar, no obstante, no podría alegarse que el solicitante de la medida cautelar es responsable por el daño que ocasionó la ejecución de la resolución o laudo que admitió la medida cautelar dado que el conflicto que motivó a llevar al mismo para ser resuelto en el proceso arbitral ha dejado de tener relevancia jurídica, acto no ocasionado por ninguna de las partes del proceso si no por el legislador. "El acto generador de responsabilidad civil no puede ser vinculado causalmente al solicitante de la medida cautelar, toda vez que la verdadera causa del daño frente al afectado con la medida cautelar ha sido un acto del legislador" (Campos H. , 2015, pág. 161)

c. Artículo 321.- Conclusión del proceso sin declaración sobre el fondo. Concluye el proceso sin declaración sobre el fondo cuando: 4. Queda consentida la resolución que ampara alguna excepción o defensa previa sin que el demandante haya cumplido con sanear la relación procesal dentro del plazo concedido conforme al Artículo 451, en los casos que así corresponda. (Grupo de trabajo encargado de revisar y proponer mejoras al Código Procesal Civil, 2018)

Respecto al inciso 4, consideramos que el supuesto en arbitraje debería ser el siguiente:

Cuando el tribunal se declare incompetente por alguna de las causales señaladas en el inciso 1 del artículo 41 de la ley que regula el arbitraje (excepciones u objeciones al arbitraje relativas a la inexistencia, nulidad, anulabilidad, invalidez o ineficacia del convenio arbitral, prescripción, caducidad, cosa juzgada, etc). (Congreso de la República del Perú, 2008)

Nuevamente, sobre este supuesto consideramos que si debe ser un motivo por el cual se levante la medida cautelar. Sin embargo, no cabe posibilidad de que el tribunal arbitral se pronuncie respecto a la responsabilidad del solicitante de la medida cautelar cuando se declare incompetente, motivo por el cual es el juez quien debe resolver este conflicto, objeto que no tiene la presente investigación.

Sin perjuicio de ello, en el escenario en el que se realice otro proceso arbitral cuyo conflicto esté relacionado al que motivo la concesión de la medida cautelar la cual "no debió haberse otorgado" el tribunal si podría pronunciarse sobre la indemnización por la ejecución de la medida cautelar. 
d. Artículo 321.- Conclusión del proceso sin declaración sobre el fondo. Concluye el proceso sin declaración sobre el fondo cuando: Sobreviene consolidación en los derechos de los litigantes (Grupo de trabajo encargado de revisar y proponer mejoras al Código Procesal Civil, 2018)

Por último, este es un fundamento por el que se debe levantar la medida cautelar. No obstante, no se debería solicitar la responsabilidad por el posible daño ocasionado a quien ejecutó la resolución o laudo que declaró admitida la medida cautelar por la identidad entre el demandante y demandado en virtud de la adquisición de derechos y obligaciones del primero respecto del segundo o viceversa. En ese sentido, no habría obligación de resarcir a un tercero.

Supuestos que determinan que la medida cautelar se haya otorgado de acuerdo a la propuesta de formas de conclusión del proceso sin declaración del fondo.

a) Artículo 321.- Conclusión del proceso sin declaración sobre el fondo. Concluye el proceso sin declaración sobre el fondo cuando: 3. Se declara el abandono del proceso; (Grupo de trabajo encargado de revisar y proponer mejoras al Código Procesal Civil, 2018)

Este supuesto se ha desarrollado en el literal c del título de la presente investigación "Supuestos que determinan que la medida cautelar no debió haberse otorgado", la cual repetimos como fundamento.

b) Artículo 321.- Conclusión del proceso sin declaración sobre el fondo. Concluye el proceso sin declaración sobre el fondo cuando: 5. El demandante se desiste del proceso. (Grupo de trabajo encargado de revisar y proponer mejoras al Código Procesal Civil, 2018)

En ese mismo sentido, el desistimiento del proceso es un acto voluntario del demandante quien decidió no continuar más con el proceso, sin embargo, ya se había otorgado una medida cautelar que debía ejecutar el demandante. Por lo que la declaración del demandante de no continuar más con el proceso perjudica a quien haya ejecutado la resolución cautelar dado que tuvo que asumir el costo de ejecutarla cuando no habría una decisión final que salvaguardar.

Supuestos que no determinan que la medida cautelar se haya otorgado de acuerdo a la propuesta de formas de conclusión del proceso sin declaración del fondo. 
a. Artículo 322.- Conclusión del proceso con declaración sobre el fondo. Concluye el proceso con declaración sobre el fondo cuando: 3. El demandado reconoce la demanda o se allana al petitorio; (Grupo de trabajo encargado de revisar y proponer mejoras al Código Procesal Civil, 2018)

Dado que, el allanamiento o reconocimiento del demandado de la demanda es una aceptación de la pretensión del demandante y el segundo el consentimiento de la pretensión y veracidad de los hechos jurídicos expuestos en la demanda, no deben ser considerados como actos generadores de responsabilidad al ser ambos actos voluntarios del demandado. Además al tratarse de un acto propio, no cabe la posibilidad de que un tercero resarza el daño que este mismo se haya provocado.

b. Artículo 322.- Conclusión del proceso con declaración sobre el fondo. Concluye el proceso con declaración sobre el fondo cuando: 2. Las partes concilian; 4. Las partes transigen. (Grupo de trabajo encargado de revisar y proponer mejoras al Código Procesal Civil, 2018)

Si bien este escenario provoca que la medida cautelar sea levantada, ello no es suficiente para que se determine la responsabilidad civil por los daños ocasionados por la ejecución de una medida cautelar dado que en la transacción o conciliación ya se ha resuelto el conflicto. Motivo por el cual, este debe ser una limitación a la obligación de resarcir, siempre que este convenio sea válido.

Supuestos que determinan que la medida cautelar se haya otorgado de acuerdo a la propuesta de formas de conclusión del proceso sin declaración del fondo.

a. Artículo 322.- Conclusión del proceso con declaración sobre el fondo. Concluye el proceso con declaración sobre el fondo cuando: 1. El juez declara, en definitiva, fundada o infundada la demanda. (Grupo de trabajo encargado de revisar y proponer mejoras al Código Procesal Civil, 2018)

La declaración infundada de la demanda, debido al todo el tiempo que se demoró para obtener esta decisión mientras que el demandado tuvo la obligación de ejecutar una medida que tuvo como objetivo asegurar una decisión final que no otorgó lo que pretendía el demandante.

Sobre la declaración de fundada la demanda, se debe tener presente lo indicado por Veramendi: 
Consideramos que se debe tener presente que aun así la pretensión contenida en la demanda haya sido declarada fundada, si esta está asegurada con una medida cautelar, puede causar daños y perjuicios que deberían ser resarcidos al ejecutado. Tal sería el supuesto en el cual se solicite una medida cautelar innecesaria o excesiva en uso abusivo de la cautela y al que hace referencia la primera parte del art. $627^{\circ}$ del Código Procesal Civil. En efecto, si la pretensión se encuentra suficientemente garantizada y pese a ello se solicita una medida cautelar, el ejecutante de la medida cautelar será responsable de los daños y perjuicios, aún así la demanda se declara fundada. La idea es evitar que la medida cautelar se convierta en un instrumento de abuso de derecho, contraviniendo los fines mismos de la institución cautelar. (Veramendi, 2003)

Siendo ello así, puede solicitarse la indemnización por ejecución de una resolución o laudo que otorgue una medida cautelar cuando esta haya sido abusiva, es decir hubo mejores formas de protección a la pretensión que no hubiesen sido tan gravosas como aquella que se otorgó.

b. Artículo 322.- Conclusión del proceso con declaración sobre el fondo. Concluye el proceso con declaración sobre el fondo cuando: 5. El demandante renuncia al derecho que sustenta su pretensión o se desiste de su pretensión.

La renuncia del derecho que sustenta la pretensión o desistimiento del proceso como acto generador de responsabilidad tiene el mismo argumento expuesto en el desistimiento del proceso.

c. Artículo 322.- Conclusión del proceso con declaración sobre el fondo. Concluye el proceso con declaración sobre el fondo cuando: 6. Cuando el juez declara la caducidad del derecho.

La declaración de caducidad del derecho es un acto generador de responsabilidad en virtud de la extinción del derecho y la acción. Ello quiere decir que la medida cautelar aseguraba una decisión final respecto de un derecho inexistente. En consecuencia, el haber ejecutado una resolución cautelar que protegía la eficacia de la decisión final de un proceso en cual se discutía sobre un derecho extinto ocasiona un daño al ejecutante, que debe ser indemnizado por el solicitante de la medida cautelar (quien conocía el plazo de caducidad de su derecho) 
Procedimiento para determinar el conflicto derivado por el daño provocado por una resolución cautelar.

La responsabilidad generada a consecuencia de la ejecución de una medida provisional se determinará después de ocurrido los siguientes sucesos:

a. Cuando se dispone el levantamiento o revocación de la medida provisional por parte del juez superior;

b. Que el árbitro deje sin efecto la medida cautelar dictada por una autoridad judicial, situación establecida por el inciso 6 del artículo 47 de la ley que regula el arbitraje;

c. El abandono del proceso;

d. El desistimiento del proceso;

e. El demandante renuncia al derecho que sustenta su pretensión o se desiste de su pretensión;

f. La declaración de fundada e infundada la demanda;

g. La declaración de caducidad del derecho; o

h. En los demás casos previstos en las disposiciones legales.

Sin perjuicio de ello, consideramos que no debe ser una lista taxativa al encontrarnos en un sistema de responsabilidad de carácter atípico, motivo por el cual, cabe la posibilidad de que existan otros supuestos que puedan provocar que el tribunal arbitral se pronuncie respecto este conflicto.

El afectado con la medida debe precisar al tribunal arbitral el daño ocasionado y argumentar que el mismo se ocasionó en virtud de la ejecución de la medida cautelar, adjuntando los medios probatorios que acrediten tal hecho. El beneficiario de la medida cautelar debe absolver sobre el particular dentro del plazo de seis días. El tribunal deberá resolver sobre este conflicto con o sin la absolución.

El monto indemnizatorio dispuesto debe justificarse en los medios probatorios ofrecidos. Cuando por la naturaleza del daño, sea material o moral, no pueda establecerse de manera precisa el monto indemnizatorio, se podrá establecer en base a un criterio equitativo. (Campos H. , 2018, pág. 294)

Cabe resaltar que el pronunciamiento respecto a este conflicto debe realizarse en el laudo con la finalidad que no existan inconvenientes para su ejecución. Dado que este 
es el único título ejecutivo que la ley reconoce para iniciar la ejecución de la decisión del tribunal arbitral.

Sin perjuicio de ello, se debe destacar que en aquellos casos que la determinación que la medida cautelar no debió haberse otorgado se realice en el pronunciamiento del laudo, la parte interesada debe "adelantarse" a la producción de este evento.

Por ejemplo, en el caso se haya otorgado una medida cautelar antes del proceso en la contestación de demanda, se podría reconvenir solicitando que en el supuesto se declare infundada la demanda, se debe otorgar una indemnización por los daños y perjuicios que ocasione la ejecución de resolución o laudo que concedió la tutela cautelar cuando esta no debió haberse otorgado.

Esto con la finalidad de que el tribunal arbitral deba pronunciarse sobre esta solicitud en el laudo, y en caso no se realice, pese al pedido, se pueda solicitar una integración de laudo. De lo contrario, el tribunal no podrá pronunciarse, dado que con la emisión del laudo se concluyen las actuaciones arbitrales y se paralizan las funciones del tribunal arbitrales, conforme lo señala el artículo 60 de la ley que regula el arbitraje. 


\section{Conclusiones}

\section{General.}

Los tribunales arbitrales tienen la facultad de resolver respecto aquel que conflicto que se origine por el daño provocado por la ejecución de una resolución o laudo que otorga la medida cautelar pese a que este sea de naturaleza extracontractual.

\section{Específicos.}

1. La discusión sobre responsabilidad por el perjuicio que ocasione la ejecución de una medida cautelar no excede de aquel convenio arbitral que señala que aquellas controversias que deriven de una determinada relación jurídica se resolverá a través de arbitraje.

2. La indemnización por los daños ocasionados por la ejecución de un laudo o resolución que otorgue una medida cautelar es otorgada a solicitud de parte.

3. La responsabilidad generada a consecuencia de la ejecución de una medida provisional se determinará después de ocurrido los siguientes sucesos:

a. Cuando se dispone el levantamiento o revocación de la medida provisional por parte del juez superior;

b. Que el árbitro deje sin efecto la medida cautelar dictada por una autoridad judicial, situación establecida por el inciso 6 del artículo 47 de la ley que regula el arbitraje;

c. El abandono del proceso;

d. El desistimiento del proceso;

e. El demandante renuncia al derecho que sustenta su pretensión o se desiste de su pretensión;

f. La declaración de infundada la demanda;

g. La conciliación y transacción, siempre que en estos no se hayan incluido este conflicto;

h. La declaración de caducidad del derecho; o

i. En los demás casos previstos en las disposiciones legales. 
No obstante, esta lista no debe ser taxativa al encontrarnos en un sistema de responsabilidad civil atípica.

El afectado con la medida debe precisar al tribunal arbitral el daño ocasionado y argumentar que el mismo se ocasionó en virtud de la ejecución de la medida cautelar, adjuntando los medios probatorios que acrediten tal hecho. El beneficiario de la medida cautelar debe absolver sobre el particular dentro del plazo de seis días. El tribunal deberá resolver sobre este conflicto con o sin la absolución.

El monto indemnizatorio dispuesto debe justificarse en los medios probatorios ofrecidos. Cuando por la naturaleza del daño, sea material o moral, no pueda establecerse de manera precisa el monto indemnizatorio, se podrá establecer en base a un criterio equitativo. (Campos H. , 2018, pág. 294)

\section{Recomendaciones}

1. Los tribunales arbitrales deben resolver respecto el otorgamiento o no de indemnización por el daño ocasionado por la ejecución de una resolución o laudo que otorgue una medida cautelar en el laudo con el objetivo que no existan inconvenientes en su ejecución, dado que este si es considerado un título ejecutivo de acuerdo al inciso 2 del artículo 688.

2. Es necesario tener presente que la antijuricidad no es un elemento de la responsabilidad civil, de lo contrario puede afirmarse que no existe responsabilidad civil por actos lícitos, como lo es la ejecución una resolución o laudo que otorgue una medida cautelar, la cual conforme se ha expuesto puede causar daños.

Esta premisa es fundamentada por las siguientes razones:

- La antijuricidad o ilicitud no constituyen una categoría normativa en nuestra regulación de responsabilidad civil, la cual es confirmada en que todos los artículos que nuestra normativa, contenida en el Código Civil, dispone para la regulación de la responsabilidad extracontractual en ninguna de ellas se hace referencia al termino <<antijuricidad>>, con mayor razón cuando el legislador de manera expresa extrajo por completo la referencia al $<$ hecho ilícito >> cuando se ha querido referir a la responsabilidad civil. (Campos H. , 2013, pág. 263)

- La responsabilidad civil no tiene como función sancionar una determinada conducta, si no proteger una esfera jurídica subjetiva. 
- La resarcibilidad del daño ya no se valora en función de la existencia o inexistencia de una protección del ordenamiento al interés lesionado, sino en función de la existencia o inexistencia de una protección del ordenamiento al interés del dañador en desarrollar una determinada actividad, aun a costa de un sacrificio económico ajeno. (Schlesinger, 2001, pág. 55) Esto se relaciona con la relatividad de los derechos, los cuales no son de carácter absoluto. 


\section{Referencias}

Ariano, E. (2012). Consideraciones sobre la conclusión del Proceso Contencioso Administrativo por reconocimiento de la pretensión en la Vía Administrativa. Circulo de Derecho Administrativo, 143-154.

Ariano, E. (2013). Arbitraje, tutela cautelar e imparcialidad objetiva del juzgador: un tema para el debate. Athina, 107-125.

Asamblea Federal Suiza. (2008). Ley Suiza sobre el arbitraje interno. Civil Procedure Code [Código de Procedimiento Civil]. Suiza.

Barchi, L. (2013). El convenio arbitral en el Decreto Legislativo 1071. Ius et Praxis, 90.

Born, G. (2009). International Commercial Arbitration [Arbitraje Comercial Internacional]. Paises Bajos: Kluwer Law International.

Bullard, A. (2012). ¿Qué fue primero: el huevo o la gallina? El carácter contractual del recurso de anulación. Revista Derecho y Sociedad, 17-31.

Bullard, A. (2012). ¿Qué fue primero: el huevo o la gallina? El carácter contractual del recurso de anulación. Revista Derecho y Sociedad, 17-31.

Caivano, J. (2008). Arbitraje. Buenos Aires: Ad-Hoc.

Caivano, J. (2013). Arbitrabilidad y Orden Público. Foro Jurídico, 64.

Caivano, J. (2013). Arbitrabilidad y Orden Público. Foro Jurídico, 64.

Caivano, R. (2015). El contrato de arbitraje y su autonomía respecto del contrato que lo contiene. Derecho y Ciencias Sociales, 13-39.

Calamandrei, P. (2005). Introducción al estudio sistemático de las medidas cautelares. Lima: Ara Editores.

Cámara de Comercio Americana del Perú. (2013). Reglamento de Arbitraje de la Cámara de Comercio Americana del Perú. Obtenido de https://amcham.org.pe/wpcontent/uploads/2018/11/Reglamento-2013.pdf

Cámara de Comercio de Lima. (2017). Reglamento de Arbitraje de la Cámara de Comercio de Lima. Obtenido de https://www.camaralima.org.pe/repositorioaps/0/0/par/reglamentoarbitraje2017/reg lamento_ccl_2017.pdf 
Campos, H. (2012). El juicio de resarcibilidad en el ordenamiento jurídico peruano. lus Et Veritas, 221-222.

Campos, H. (2013). El ámbito dual del juicio de resarcibilidad en el ordenamiento jurídico peruano. Derecho \& Sociedad, 257-272.

Campos, H. (2015). Breves apuntes sobre el acto genereador de responsabilidad derivado de la actuación de resoluciones cautelares. Actualidad Jurídica, 156 175.

Campos, H. (2015). La caución contracautela en el ordenamiento jurídico peruano. En G.

\&. Priori, Sobre la tutela cautelar. Lima: Themis.

Campos, H. (2018). Responsabilidad civil y medidas provisionales: Breves anotaciones a la propuesta de reforma del Código Procesal Civil Peruano. Derecho y Sociedad, 283-295.

Campos, H. A. (16 de Diciembre de 2013). Ius 360. Obtenido de lus 360: http://ius360.com/privado/civil/el-que-gana-pierde-segunda-parte/

Campos, H. A. (2013). Premisa para un estudio sistemático de tutela resarcitoria de los daños derivados de la ejecución de una medida cautelar. En R. S. al., Estudios de Derecho Procesal Civil (pág. 763). Lima: Ius Et Veritas.

Cantuarias, F. (1994). El arbitraje en el Perú: desarrollo actual y perspectivas futuras. Lima: Fundación M.J. Bustamante.

Cantuarias, F., \& Repetto, J. (2014). La naturaleza jurídica del Arbitraje según el Tribunal Constitucional peruano: Riesgos en el camino. Forseti, 99.

Castillo, M., Sabroso, R., \& Chipana, J. (2013). La constitución del tribunal arbitral y las medidas cautelares en el arbitrae. Arbitraje Pucp, 13-14.

Centro de Análisis y Resolución de Conflictos PUCP. (2017). Reglamento Arbitraje PUCP. Obtenido de http://cdn01.pucp.education/carc/wpcontent/uploads/2017/07/14210602/arb_norm_03_regarb-centan-y-resol.pdf

Congreso de la República. (22 de abril de 1993). Tuo del Código Procesal Civil. Lima.

Congreso de la República del Perú. (2008). Decreto Legislativo que norma el arbitraje.

Obtenido de http://spijlibre.minjus.gob.pe/normativa_libre/main.asp 
Córdova, J. (2015). El principio de Kompetenz - Kompetenz: algunas consideraciones a partir de la jurisprudencia. Instituto Pacifíco, 282-292.

Cossio, C. (1940). Sustrato filosófico de los métodos interpretativos. Jurisprudencia Argentina, 25-42.

Couture, E. (19 de 04 de 1945). Proyecto de Código de Procedimiento Civil de 1945. Montevideo.

De Trazegenis, F. (2004). "El rasgado del velo societario para determinar la competencia dentro del arbitraje". Ius Et Veritas, 21.

De Trazegnies, F. (1988). Responsabilidad Civil, Biblioteca para leer el Código Civil, Vol. IV, Tomo I. Lima: Pontificia Universidad Católica del Perú.

Espinoza, J. (2013). Derecho de la Responsabilidad Civil. Lima: Rodhas.

Espinoza, J. (2013). Derecho de la Responsabilidad Civil. Lima: Rodhas.

Fernandez, G. (2019). Introducción a la Responsabilidad Civil. Lima: Fondo Editorial PUCP.

Garderes, S. (2003). El sistema de la responsabilidad cautelar. Revista uruguaya de derecho procesal, 23-41.

Ghersi, C., Stiglitz, G., \& Parellada, C. (1997). Responsabilidad Civil. Buenas Aires: Hammurabi.

Gonzáles, F. (2006). Gonzáles de Cossio Abogados S.C. Obtenido de http://www.gdca.com.mx/PDF/arbitraje/KOMPETENZ\%20A\%20LA\%20MEXICAN A.pdf

Grupo de trabajo encargado de revisar y proponer mejoras al Código Procesal Civil. (05 de Marzo de 2018). Gaceta Jurídica. Obtenido de http://www.gacetajuridica.com.pe/boletin-nvnet/ar-web/CPC.pdf

Guastini, R. (2011). Disposición vs. Norma. En G. Tarello, L. Montesano, P. Chiassoni, R. Guastini, T. Ascarelli, \& V. Crisafulli, Disposición vs. Norma (pág. 136). Lima: Palestra.

Guastini, R. (2011). Introducción a la Teoría de la Interpretación. En G. Tarello, L. Montesano, P. Chiassoni, R. Guastini, T. Ascarelli, \& V. Crisafulli, Disposición vs. Norma (págs. 157-165). Lima: Palestra. 
Guastini, R. (2016). Fuentes del Derecho, Fundamentos Teóricos. Lima: Raguel Ediciones.

Guastini, R. (2018). Interpretar, construir, argumentar. En R. Guastini, Filosofiía del derecho positivo. Lima: Palestra Editores.

Hernández, R. (2014). Metodología de la Investigación, Sexta Edición. México D.F.: McGraw Hill.

Hurtado, M. (2006). Tutela urgente cautelar. En Tutela jurisdiccional diferenciada. Lima: Palestra.

Las Cortes Generales. (08 de 01 de 2000). Ley de Enjuiciamiento Civil.

Lava, C. (2012). Independencia del convenio arbitral y el competence - competence en el arbitraje comercial internacional. Themis, 345-361.

Ledesma, M. (2010). Jurisdicción y Arbitraje. Lima: Pontificia Universidad Católica del Perú.

Ledesma, M. (2013). La tutela cautelar en el proceso civil. Lima: Gaceta Jurídica.

Ledesma, M. (2013). La Tutela Cautelar en el Proceso Civil. Lima: Gaceta Juridica.

Ledesma, M. (2013). La Tutela Cautelar en el Proceso Civil. Lima: Gaceta Juridica.

Lew, J., Mistelis, L., \& Kröll, S. (2003). Comparative International Comercial Arbitration [Arbitraje Comercial Internacional Comparado]. Riverwoods: Kluwer Law International.

Lohmann, J. (1988). El arbitraje. En J. G. Lohmann Luca De Tena, Para leer el Código Civil (pág. 41). Lima: Fondo Editorial de la Pontificia Universidad Católica del Perú.

Lohmann, J. (2005). Mas Sobre las Modificaciones a la Ley General de Arbitraje. Dereecho \& Sociedad, 215-226.

Mallandrich, N. (2010). Medias cautelares y arbitraje . Barcelona: Atelier.

Mazeud, H., \& Mazeud, L. (1957). Tratado teórico practico de la responsabilidad civil delictual y contractual. Tomo 1, Volumen 1. Buenos Aires: Ediciones Jurídicas Europa-America.

Monroy, J. (2002). Bases para la formación de una teoría cautelar . Lima: Comunidad. 
Monroy, J. (2017). Temas de Derecho de Procesal. Lima: Communitas.

Monroy, J. (2017). Teoria General del Proceso, IV edición. Lima: Communitas.

Montero, J. (1995). Derecho Jurisdiccional. Lima: Boch.

Orteaga, M. A. (2011). Responsabilidad Civil y Seguros. Ius Et Veritas, 62.

Poder Judicial. (2018). Bboletin Informativo.

Poder Judicial. (2019). Boletín Estadistico Institucional.

Podetti, R. (1956). Tratado de las medidas cautelares. Buenos Aires: Ediar Editores.

Polacco, V. (1898). Le obbligazioni nel diritto civile italiano. Verona-Padua: F.lli Drucker.

Priori, G. (2006). La tutela cautelar: su configuración como derecho fundamental. Lima: Ara Editores.

Proto, A. (2018). La tutela cautelar. En Lecciones del derecho procesal civil. Lima: Palestra.

Repetto, J., Hundskopf, A., \& Valderrama, M. (2014). Mi otro yo La doctrina del alter ego y el articulo 14 de la ley peruana de arbitraje. Forseti, 206-226.

Rubio, R. (2010 / 2011). El principio Competence-Competence en la nueva Ley Peruana de Arbitraje. Lima Arbitration, 101-118.

Schlesinger, P. (2001). Estudios sobre la responsabilidad civil. Lima: Ara.

Soto, C. (2011). Comentarios a la Ley Peruana de Arbitraje. Lima: Instituto Peruano de Arbitraje Comercial y Arbitraje de Inversiones.

Tarello, G. (2018). La Actividad Interpretativa. En G. Tarello, La interpretación de la ley (págs. 105-106). Lima: Palestra Editores.

Tribunal Constitucional. (03 de Enero de 2003). Sentencia del expediente 010-2002Al/TC. Obtenido de https://www.tc.gob.pe/jurisprudencia/2003/00010-2002-Al.html

Tribunal Constitucional. (30 de Noviembre de 2004). Sentencia del expediente № 0001 2004-CC/TC. Obtenido de https://www.tc.gob.pe/jurisprudencia/2004/00001-2004CC.html

Tribunal Constitucional. (07 de Diciembre de 2005). Sentencia del exp. $N \cong 4677-2004-$ PA/TC . Obtenido de http://www.tc.gob.pe/jurisprudencia/2005/04677-2004-AA.pdf 
Tribunal Constitucional. (28 de febrero de 2006). Sentencia del expediente $N^{\circ} 6167-2005-$ PHC/TC. Obtenido de http://tc.gob.pe/jurisprudencia/2006/06167-2005-HC.pdf

Tribunal Constitucional Peruano. (11 de Noviembre de 2003). Sentencia del exp. 0082003-Al/TC. Obtenido de https://www.tc.gob.pe/jurisprudencia/2003/00008-2003Al.html

Tribunal Constitucional Peruano. (18 de Diciembre de 2007). Sentencia del exp. № $6612-$ 2005-PA/TC. Obtenido de http://www.tc.gob.pe/jurisprudencia/2007/06612-2005AA.pdf

Trigo, F. (1978). Seguros y responsabilidad civil. En F. Trigo Represas, Responsabilidad civil de los profesionales (págs. 25-26). Buenos Aires: Astrea.

Vega, D. (2017). La incorporación del árbitro de emergencia en nuestro ordenamiento. Arbitraje PUCP, 36.

Veramendi, E. (2003). Restricción a la tutela jurisdiccional efectiva en la pretensión de indemnización por ejecución de medida cautelar innecesaria o maliciosa. Actualidad Juridica, 63-73.

Zavaleta, R. (21 de Octubre de 2012). Derecho \& Sociedad - Revistas PUCP. Obtenido de Derecho \& Sociedad - Revistas PUCP: http://blog.pucp.edu.pe/blog/derysoc/2012/10/21/la-argumentacion-juridica-y-lainterpretacion-del-articulo-621-del-codigo-procesal-civil-el-que-gana-pierde-rogere-zavaleta-rodriguez/ 
Anexos

\section{Matriz de Consistencia}

\begin{tabular}{|c|c|c|c|c|}
\hline & Problema & Objetivos & Hipótesis & Metodología \\
\hline General & $\begin{array}{l}\text { ¿Cómo se puede interpretar } \\
\text { el inciso } 8 \text { del artículo } 47 \text { del } \\
\text { Decreto Legislativo } 1071 \text {, en } \\
\text { específico la facultad del } \\
\text { tribunal arbitral de condonar } \\
\text { por el pago de los daños } \\
\text { ocasionados por la ejecución } \\
\text { de una medida cautelar, } \\
\text { cuando ésta es otorgada por } \\
\text { el árbitro de emergencia? }\end{array}$ & $\begin{array}{l}\text { Analizar las posibles } \\
\text { interpretaciones sobre la } \\
\text { facultad del tribunal arbitral } \\
\text { de condonar por el pago de } \\
\text { los daños ocasionados por la } \\
\text { ejecución de una medida } \\
\text { cautelar, cuando ésta es } \\
\text { otorgada por el árbitro de } \\
\text { emergencia, establecida así } \\
\text { en el inciso } 8 \text { del artículo } 47 \\
\text { de la ley peruana que regula } \\
\text { el arbitraje }\end{array}$ & $\begin{array}{l}\text { Los tribunales arbitrales } \\
\text { están facultados de requerir } \\
\text { el resarcimiento por el daño } \\
\text { que ocasione la ejecución de } \\
\text { la medida cautelar, al } \\
\text { someterse a la ley peruana } \\
\text { de arbitraje, Decreto } \\
\text { Legislativo 1071. }\end{array}$ & $\begin{array}{l}\text { Tipo de Investigación } \\
\text { Por la complejidad del } \\
\text { estudio: Descriptivo } \\
\text { Por el tipo de análisis de } \\
\text { la información recolectada } \\
\text { cualitativo. }\end{array}$ \\
\hline Específicos & $\begin{array}{l}\text { 1. La discusión sobre la } \\
\text { responsabilidad por el } \\
\text { perjuicio que ocasione la } \\
\text { ejecución de una medida } \\
\text { cautelar ¿excede de lo } \\
\text { pactado al celebrarse un } \\
\text { convenio arbitral que señala } \\
\text { que aquellas controversias } \\
\text { que deriven de determinada } \\
\text { relación jurídica r se } \\
\text { resolverán a través de } \\
\text { arbitraje? }\end{array}$ & $\begin{array}{l}\text { 1. Revisar si la discusión } \\
\text { sobre la responsabilidad por } \\
\text { el perjuicio que ocasione la } \\
\text { ejecución de una medida } \\
\text { cautelar en el proceso arbitral } \\
\text { excede o no de lo pactado al } \\
\text { celebrarse el convenio } \\
\text { arbitral. }\end{array}$ & $\begin{array}{l}\text { 1. El debate sobre la } \\
\text { responsabilidad por el } \\
\text { perjuicio que ocasione la } \\
\text { ejecución de una medida } \\
\text { cautelar en el proceso arbitral } \\
\text { no excede de lo pactado al } \\
\text { celebrar el convenio arbitral. }\end{array}$ & $\begin{array}{l}\text { Diseño de Investigación } \\
\text { Teoría fundamentada, en } \\
\text { particular, el teórico. }\end{array}$ \\
\hline
\end{tabular}




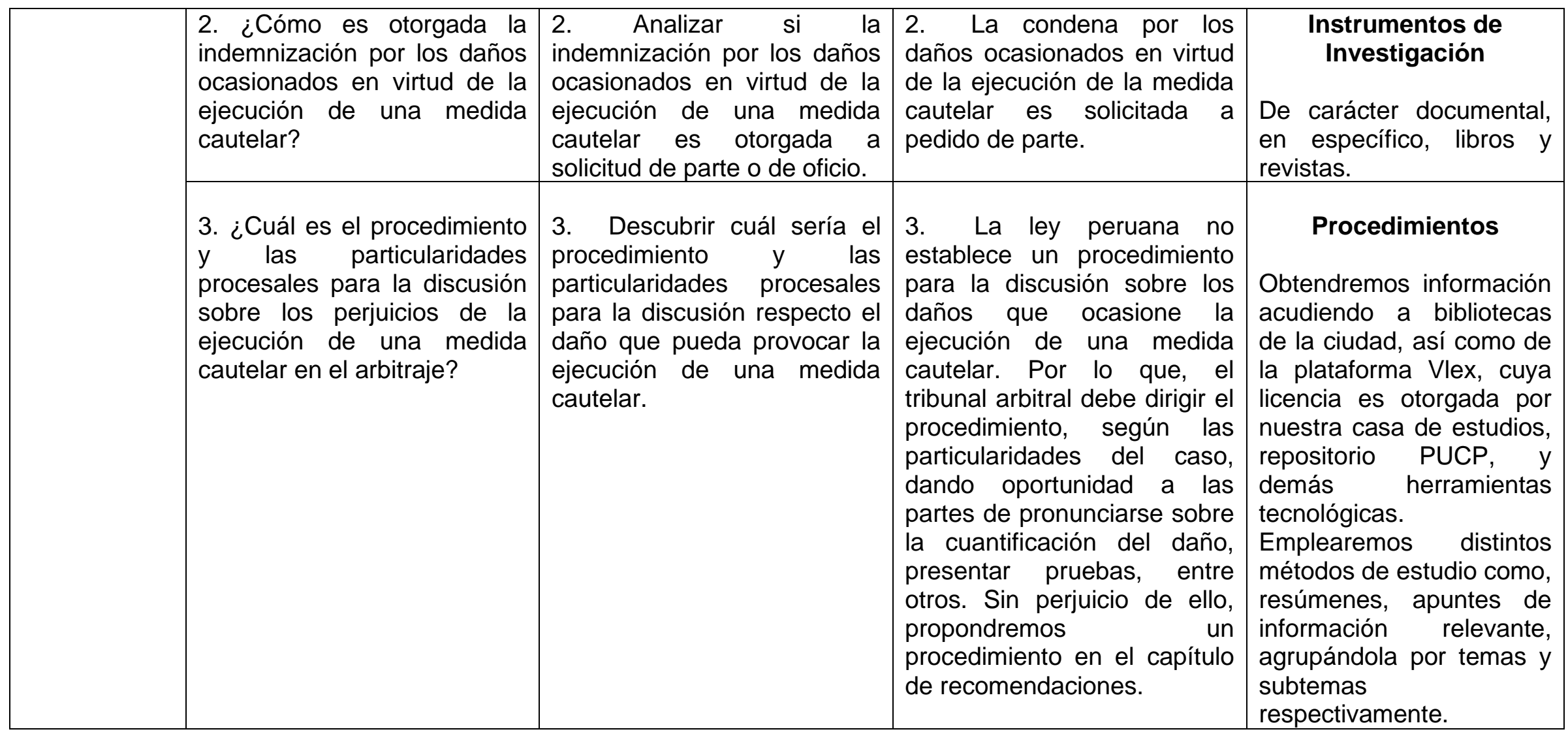




\section{Entrevistas}

\section{Entrevista al profesor Hector Campos García.}

A.R.: Profesor, quisiera preguntarle sobre los actos generadores del daño derivado de las resoluciones o laudos que concedan una medida cautelar. Esta pregunta es general, pero va de la mano con la propuesta de reforma del CPC que indicaba que aquellas formas de conclusión del proceso y aquellas algunas formas del levantamiento de la medida cautelar, esos los podría tomar como base. Pero yo recuerdo haber leído artículos de usted que denomina actos generadores del daño a estos supuestos y me preguntaba, ¿es correcto denominarlo como tal acto generador del daño? Porque conversando también con otros profesores sobre esto, me indicaron de que el acto generador del daño en sí es la ejecución de esta resolución o laudo que otorga la medida cautelar. No sé si me podría explicar un poco, porque yo estaba tomando de base esos supuestos y los denominaba actos generadores del daño, conforme a las lecturas que usted me había brindado y también lo que había escrito, pero surgió mi duda.

H.C.: Sí, lo que yo sostengo es que el acto generador es un acto de carácter complejo, es decir, no basta la sola constatación de la ejecución de la medida cautelar para considerar que el acto generador se ha producido porque, pensando por ejemplo en el esquema procesal normal, solicitas la cautelar, se te concede la cautelar y se ejecuta la cautelar. Pero, si al final ganaste el proceso, no vas a estar frente a un acto generador de daño, porque, a pesar de que efectivamente se ha producido la ejecución de la medida cautelar, eso muestra desde mi punto de vista que es insuficiente el afirmar que el acto generador de responsabilidad se agota con la ejecución. Entonces yo creo, por esto, que de cara a un juicio de responsabilidad, en el análisis de responsabilidad hay que prestar atención al fenómeno en su complejidad y eso implica ver sí, el acto de ejecución de la cautelar, pero adicionalmente prestar atención al proceso de fondo y al resultado. Si eso lo trasladamos un poco al ámbito arbitral, y aquí estoy pensando en voz alta porque a este tema no le he dado muchas vueltas, lo que tendríamos que decir es que tendríamos que tener en cuenta, tanto la orden procesal que concede la cautelar y los actos de ejecución correspondientes, como el resultado del laudo final en el cual se resuelva la controversia. Eso sería lo que pienso.

A.R.: Entonces, por ejemplo, siguiendo los supuestos que señala el proyecto de reforma, un acto generador del daño sería aquella ejecución de la medida cautelar 
cuyo proceso principal fue declarado infundado. O sea, todo este acto en sí, sería el acto generador del daño.

H.C.: Correcto, el acto generador es un acto complejo. No basta solo la ejecución si no sabes cómo acabó el proceso. No basta que haya acabado el proceso, si es que no ha habido una ejecución.

A.R.: Sí, yo lo pensaba así, pero con otros profesores me mareé un poco, pero así como lo explica sí me queda más claro, profesor.

H.C.: Para ponerlo en otros términos, la ejecución es necesaria pero no suficiente para configurar el acto generador de responsabilidad.

A.R.: Claro, se debe generar otro hecho más para que haya responsabilidad, como son los supuestos de la reforma.

H.C.: Correcto.

A.R.: Ya, profesor. Gracias. Continuando sobre los actos generadores del daño, quisiera preguntarle, ¿usted cree que todos los actos que la propuesta de reforma señala son correctos? O considera que no se deba entrar dentro de esta lista como supuestos que podrían generar daño. Yo recuerdo haber leído una lectura de usted del 2015, donde no específicamente habla sobre ese proyecto de reforma, sino un proyecto del profesor Monroy.

H.C.: Anterior.

A.R.: Sí. Señala, por ejemplo, en caso de que por un acto del legislador, un caso deja de ser justiciable. Entonces, dentro de esa línea, ¿usted considera si hay más actos que no deberían ser considerados como actos generadores del daño?

H.C.: A ver, lo que yo creo es que se declare infundada la demanda no tiene por qué ser, dentro de un diseño legislativo, el único escenario en el cual se tenga que tomar en cuenta para determinar que estamos frente a un acto generador. No recuerdo ahorita, recuerdo haberlo analizado, pero no tengo ahorita en mente cuáles son los supuestos de actos generadores que establece el proyecto de reforma del Código Procesal. No sé si lo has revisado, pero yo tengo escrito un comentario a esa reforma

A.R.: Sí, sí lo vi. Pero como que señala más respecto al dolo, ¿no? Como que el proyecto de reforma señala que, sin importar el dolo o culpa, se puede establecer la responsabilidad, pero como que no habla tanto sobre los actos en sí. Pero, en este artículo ya un poco más viejito, del 2015, así lo explica y bastante bien, y por ello, 
como en el proyecto de reforma se han incluido más supuestos que los del proyecto del profesor Monroy, entonces no sé si usted ha analizado.

H.C.: De lo que recuerdo, el proyecto de Monroy sí se hacía referencia al dolo y efectivamente yo realizo ahí un comentario. Pero, ahí hay que tener en cuenta cuál es el rol que le vamos a reconocer al dolo en este caso de responsabilidad. Es decir, el dolo está ubicado más que como un acto generador, como un criterio de imputación. Calificar que una determinada conducta es dolosa, te sirve para la imputación de responsabilidad. Entonces, si es así, pues entonces más sustento podría tener la propuesta de reforma de la comisión presidida por el profesor Priori, con relación a la delimitación de cuáles son aquellos actos individualmente considerados para ser fuente o ser actos de responsabilidad.

A.R.: Ya, pero respecto a los actos en sí, ¿cuáles considera que sí deben ser actos generadores del daño del proyecto de reforma y cuáles no? Porque en el proyecto de reforma menciona que deben ser consideradas todas las formas de conclusión del proceso y cuando se levanta la medida cautelar. Entonces, de todo este grupo no sé si usted considera que sí es correcto que deben ser todos o algunos deben ser excluidos, como sí lo mencionó en el análisis del proyecto de reforma del profesor Monroy.

H.C.: Lo que quiero es tener fresco cuáles son esos eventos que genera que señala el proyecto, ¿los tienes ahí?

A.R.: Son todas las formas de conclusión del proceso, con y sin declaración del fondo, eso es sobre la declaración del proceso principal, pero también señala sobre el proceso cautelar en sí, las formas en cómo se levanta la medida.

H.C.: Claro, hasta donde recuerdo no tenía mayor objeción respecto de estos eventos, me parece que uno era el no presentar la demanda dentro del plazo previsto, el otro era que en el camino ya se habían declarado sentencias fundadas o improcedentes. Lo que sí me acuerdo es que teníamos que esperar a que se termine el proceso principal para poder terminar de establecer la responsabilidad. En principio, por la propia naturaleza del acto, yo recuerdo que mi juicio era más positivo porque, si bien es cierto hacer un elenco de los actos generadores de responsabilidad es conveniente, no hay que perder de vista que esto se enmarca dentro de un régimen de responsabilidad de carácter atípico y precisamente la atipicidad de un sistema de responsabilidad permite que no nos encasillemos respecto de aquellos supuestos que el legislador pueda haber establecido en particular sino que podamos inclusive, 
prescindiendo de estos y yendo un poco más allá, poder encontrar actos generadores de responsabilidad. Pero, hasta donde me acuerdo, mi juicio era positivo respecto a estos eventos señalados en el proyecto de reforma.

A.R.: Claro, gracias por eso. No lo había visto así, recordando la tipicidad. Pero, solo para mencionar nuevamente sobre su artículo respecto deñ análisis del proyecto de reforma del profesor Monroy, si usted aún considera que, por ejemplo, el profesor Monroy mencionaba que debería ser un acto generador, por ejemplo, que se sustrae la pretensión del ámbito jurisdiccional y usted recuerdo que en el artículo menciona que este no, porque es un acto del legislador. No sé si sigue continuando con esa misma línea.

H.C.: Sí, entendiendo el alcance como sustracción del ámbito jurisdiccional la intervención del legislador en específico. Porque, claro, lo que estamos analizando de por medio es la responsabilidad de la persona que solicita la cautelar. La pregunta es ¿qué incidencia tiene para afirmar la responsabilidad del solicitante que mediante un acto legislativo se haya producido la sustracción de la materia por parte de la jurisdicción? Entendiéndolo en esos términos, me reafirmo en lo dicho.

A.R.: Más que todo tenía mis dudas respecto a eso. Una última pregunta para acabar con ese tema en sí, menciona usted que las transacciones y los acuerdos de las partes para poder terminar el proceso debería ser una limitante de responsabilidad civil siempre que se haya incluido este punto, la responsabilidad por la ejecución de una resolución o laudo que otorga una medida cautelar. Sin embargo, menciona que cuando no se incluye este aspecto, se debería tener mucho más cuidado. Pero no me quedó tan claro sobre este segundo supuesto.

H.C.: Lo que pasa ahí es que; ¿cuál es el supuesto base? Tienes la medida cautelar corriendo y vas a terminar el proceso por transacción. Entonces, al momento de transar, tienes que transar sobre las consecuencias patrimoniales que se han producido dada la medida cautelar que se ha ejecutado, y eso tiene que tener un punto que se tiene que abordar dentro de la transacción. Si es que ese punto no se aborda dentro de la transacción, creo yo que podría justificarse que la parte afectada, y, me parece que esto no lo digo en el artículo, pero podría justificarse que la parte afectada ha operado una suerte de renuncia respecto de los posibles daños que se puedan generar como consecuencia de la conclusión del proceso. ¿Por qué? Porque al ser la transacción un acto bilateral y acabar la transacción en una fórmula en la cual se hacen concesiones recíprocas y se cierra una transacción indicando que no hay 
nada más que reclamar respecto de la materia controvertida de forma directa o indirecta vinculada a la misma hay daños derivados de la cautelar. Entonces, la conclusión sería; uno, si vas a cerrar una transacción cuando tienes una medida cautelar, tienes que valorar los daños si es que quieres introducirlos en la transacción, si no introduces esa liquidación de daños dentro de la transacción, o si no negocias esa transacción, yo creo que se podría legítimamente sostener que las partes han renunciado a pedir una indemnización derivada de ese supuesto en particular.

A.R.: Claro porque se concluye el proceso. Gracias, profesor, tenía mis dudas respecto a eso, respecto a los actos generadores del daño. No sé si podría volverle a preguntar respecto a las demás preguntas de la tesis, que yo recuerdo que sí me las menciono, pero nuevamente si por favor las podría volver a responder porque es muy probable que la Universidad me pida la grabación de todas las entrevistas.

H.C.: Okey.

A.R.: ¿Sí? Gracias, profesor. La primera pregunta es si si la discusión sobre responsabilidad por el perjuicio que ocasione la resolución o laudo que otorgue la medida cautelar en arbitraje excede o no en lo pactado por las partes al celebrar un convenio arbitral.

H.C.: Para ver si entendí bien, si es que ingresa dentro del ámbito del convenio arbitral el poder reclamar los daños derivados por la ejecución de un laudo que ordene una cautelar, ¿correcto?

A.R.: Sí

H.C.: Bueno, ahí lo que yo creo es que sí ingresa dentro del ámbito del convenio arbitral. Precisamente el fraseo estándar que se utiliza en los convenios arbitrales es, cualquier controversia directa o indirecta referida al presente contrato, está dentro del árbitro del convenio, dentro del ámbito del arbitraje, inclusive con cargo que puedan revisar, me parece que las reglas IBA sobre redacción de convenios arbitrales sugieren una redacción de este tipo, para evitar cualquier tipo de cuestionamiento a la competencia que podrían tener los árbitros al momento de delimitar cuáles son las controversias o conflictos que están de por medio en materia cautelar. Entonces yo sí creo que un convenio arbitral comprendería el poder discutir respecto a este tipo de daños, claro, las partes podrían excluir expresamente del convenio arbitral este tipo de daños, eso también podrían hacer. 
A.R.: Ya, profesor. La siguiente pregunta es el otorgamiento de la indemnización por los daños ocasionados en virtud de la ejecución de una resolución o laudo que otorga la medida cautelar, ¿es a solicitud de parte o de oficio?

H.C.: A solicitud de parte, necesariamente.

A.R.: Y sobre el procedimiento, profesor, ¿cuál considera usted debe ser el procedimiento en arbitraje para poder resolver este conflicto?

H.C.: Tiene que ser un procedimiento que se realice dentro del mismo arbitraje y donde, previa a la emisión del laudo a menos que esto se realice en un laudo parcial, el árbitro dé la posibilidad a las partes para que actúen en medios probatorios en los cuales se analice, precisamente, si se ha cometido un daño, si es que hay una relación de causalidad o si es que se tiene que actuar alguna prueba respecto de los daños derivados de la medida cautelar. Esto va de la mano con la pregunta anterior, porque en la pregunta anterior se decía si es que era necesaria o no la solicitud de parte, y claro, es necesaria la solicitud de parte, y en tanto es necesaria, el árbitro tiene que generar el incidente dentro del propio proceso arbitral para poder realizar la liquidación de los daños.

A.R.: Profesor, ¿y qué pasa con aquellos supuestos en los que este acto generador del daño se ocasiona después de la emisión del laudo, como es cuando se declara infundada la demanda?

H.C.: Lo que pasa es que ahí, lo que tendría que suceder es que no lo has pedido, porque si lo pediste, tienes que pronunciarte en el laudo. Si no lo pediste, el árbitro no se va a poder pronunciar.

A.R.: Claro, pero volviendo a las preguntas anteriores, si el acto generador del daño es cuando la declaración de infundada la demanda, entonces digamos que no sabes que te está ocasionando daño o digamos que no es exigible, no puedes pedirlo hasta que se declare infundada la demanda.

H.C.: No significa que no lo puedas pedir, significa que lo puedes pedir, pero que te lo concedan va a estar sujeto al resultado del propio laudo. Lo que te diría es, en caso se declare infundada la demanda en el laudo se ordene que el demandante, en este caso, está obligado al pago de una indemnización ascendente a tanto, por los daños generados como consecuencia de la ejecución de la medida cautelar. Entonces, en el mismo laudo el árbitro va a tener que pronunciarse sobre si declara fundada o infundada la demanda; pero como ha habido una solicitud de parte, si declara fundada 
la demanda, simplemente no va a ordenar que se pague ninguna indemnización porque el demandante gozó bien de la cautelar, si es que se declara infundada la demanda el árbitro en el mismo laudo va a tener que reservar sección en el cual liquide los daños; pero para que esa liquidación se pueda dar, significa que previamente se tiene que haber discutido la liquidación de los mismos en cuanto a la cuantía en el propio arbitraje.

A.R.: O sea, siempre las partes deben solicitarlo antes de la emisión del laudo, a pesar de que no se haya producido el acto generador del daño.

H.C.: Lo que pasa es que si lo pides después, el árbitro no va a ser competente para poder pronunciarse, porque el árbitro pierde competencia con la emisión del laudo.

A.R.: ¿Y no podríamos pedir una integración? Mi duda va más por la declaración de infundada la demanda, porque el acto generador es cuando te declaran infundada la demanda, pero ¿cómo puedes pedir algo sobre algo que aún no se ha producido?

H.C.: Es como cuando, en materia procesal esto se le denomina pretensiones condicionales, es decir, tú pides algo pero que está sujeto a que se verifiquen otras cosas. Por ejemplo, tú en la demanda, imagínate un proceso cualquiera; tú pides pretensión principal uno, la resolución del contrato, pretensión principal dos, indemnización de daño. Tú sabes que para que se te den los daños, necesitas que el contrato se haya considerado resuelto, necesitas además haber probado los daños, por eso ya lo estás pidiendo desde el momento uno. ¿Qué va a pasar? Que en el laudo el juez va a decir 'oye, la pretensión de la resolución fundada' ¿Esto significa que voy a declarar fundada la pretensión de indemnización? No, porque tengo que ver si es que se han producido los daños. Escenario dos, el juez o el árbitro resuelve el laudo que la pretensión de resolución es infundada porque, por ejemplo, dicen 'no ha habido incumplimiento' Entonces va a declarar infundada la pretensión de indemnización de daños porque no ha habido un incumplimiento que justifique el pago de los daños. A lo que me refiero es, tú sí puedes pedir en el momento uno, sea en la demanda o en algún momento en el proceso; por ejemplo una vez que ya se otorgó la cautelar, tú sí puedes pedir y decirle 'señor árbitro, si es que pasa tal cosa, usted ordene tal cosa. Si es que se declara el incumplimiento, ordene la resolución. Tú al momento en que estás pidiendo, no sabes si ha habido incumplimiento, es tu posición, pero no necesariamente sabes porque el laudo podría decir que sí o podría decir que no. Si el laudo dice que ha habido incumplimiento, pues entonces se cumplió la condición y se pronunciará sobre los demás requisitos que se necesita para la otra 
pretensión. Si te dijo que no hubo incumplimiento, pues entonces ya no se va a pronunciar sobre la otra pretensión porque esa otra pretensión requiere de incumplir. Lo mismo pasa en este caso, yo voy a pedir, si es que al final la demanda es declarada en infundada, que se me reconozcan los daños, y eso el árbitro lo puede hacer. Es como cuando pides costas, por ejemplo, si es que la otra parte pierde, que la otra parte pague los costos. ¿Cuándo voy a saber si he perdido o no he perdido? Recién al momento del laudo y en ese momento se reserva una parte del laudo para pronunciamiento sobre costos. Lo mismo sucedería con la responsabilidad, si es que la otra parte pierde la demanda, que se me paguen los daños. Entonces, en el laudo primero voy a tener una parte donde voy a analizar de fondo y en el cual diré fundada o infundada la demanda, luego iniciaré una parte en la que analizaré la responsabilidad por los daños derivados de la cautelar, y ahí tomando en cuenta el resultado del laudo, podré ordenar el pago de los daños o no.

A.R.: Entonces, puedo pedir la indemnización en la demanda o después en algún momento durante el proceso.

H.C.: Claro, tendría que ser después de que se presente la cautelar, después de que se haya ejecutado la cautelar. Ese es el momento para pedir.

A.R.: ¿Y no habría problema al momento de señalar el acto generador del daño o se podría poner algo así como 'en casos se ocasione daño derivado de los supuestos establecidos en el artículo tal, o si en caso estén establecidos', no habría problema en indicar eso en la pretensión?

H.C.: Lo que pasa es que si lo planteas al inicio del proceso, tú no sabes si va a haber una cautelar o no. Imagínate que estamos discutiendo una indemnización y yo te voy a demandar a ti la indemnización, y yo voy a plantear la demanda contra ti, que yo ahí pida una indemnización por la cautelar, no es el momento porque no sabes si va a haber cautelar o no, no sabes si esa cautelar se va a dar, no sabes cuáles son los daños derivados de esa cautelar. Pero, imagínate que tú planteas la demanda y la otra parte formula una reconvención, formula la reconvención y pide una medida cautelar de esa reconvención. Entonces, ¿el árbitro qué cosa va a hacer? El árbitro va a ejecutar la medida cautelar, suponiendo que hubo traslado o no hubo traslado, y este es otro tema, en el arbitraje normalmente hay traslado para la cautelar. Pero suponte que al final el árbitro dice 'otorgo la cautelar', entonces yo que ahora soy afectado con la cautelar, ahí puedo presentar al árbitro una solicitud al árbitro y decirle 'mira, ya se dictó la cautelar y añado una nueva pretensión al proceso, si es que la reconvención 
es declarada infundada, la otra parte me va a tener que pagar el monto de la indemnización ascendente a tanto o el monto de la indemnización que se liquidará al momento de emitirse el laudo'. Ese es el momento, cuando tienes la cautelar metida porque si no estás especulando. No sabes la cautelar, no sabes mucho en realidad, no sabes nada porque es completamente eventual que haya cautelar o no.

A.R.: Sí, pero mi pregunta iba más por, como la ejecución misma no ocasiona daño deberíamos señalar, después de producida la declaración de infundada la demanda o el abandono de proceso, o al abandono del proceso o declarada la incompetencia, entonces por ahí mi duda. Cuando se concede la medida cautelar ¿cómo la pides? Si aún no sabes cómo te va a afectar directamente el hecho en sí, el acto generador no se produce. Me refiero a este segundo acto. ¿Tendría que esperar a que el acto se produzca?

H.C.: En el ejemplo que te he puesto, yo te pido a ti una indemnización y tú reconvienes con el pago de otra indemnización, tú pides la medida cautelar y el árbitro te da la medida cautelar y, por ejemplo, embarga mis cuentas. Entonces, yo en ese momento le voy a decir al árbitro 'mira, árbitro, ya hay una medida cautelar que está afectando mi patrimonio, si es que la reconvención termina siendo declarada infundada, ordena a la otra parte a que me pague una indemnización cuyo monto será calculado o liquidado al momento de la emisión del laudo', podrías decir también 'estoy siendo afectado por una medida cautelar, si es que el proceso concluye declarando infundada la pretensión en la reconvención, o si el proceso concluye de cualquier otro modo en el cual se reconozca que la parte que ha reconvenido, no tiene derecho, pronúnciate sobre los daños que ha generado la medida cautelar'. Así lo pides, lo que vas a tener en el camino es un problema de actuación de medios probatorios, en el camino tú vas a tener que acreditar cuál es el daño que efectivamente has sufrido. Imagínate que efectivamente es un embargo en cuentas, por ejemplo, intereses es un tema que vas a poder pedir, ¿qué pasa si con esas cuentas o si con el dinero que estaba en esa cuenta, tú la destinabas normalmente para el pago a trabajadores o a proveedores, y como consecuencia de ello no has podido realizar los pagos, porque han quedado congeladas las cuentas, y por lo tanto han habido daños que tú has producido a terceros y que te los están pidiendo aparte? Esos daños también los puedes pedir, pero eso ya va a generar que tengas que probar sobre los mismos.

A.R.: Ahora sí me queda claro. Tendrás que adelantarte un poco, pero no tanto. 
H.C.: Exacto, es adelantarte para pedirlo en el escenario en que pase que el laudo reconozca que el que solicitó la cautelar no tenía derecho. Porque si no lo pides, no lo vas a poder, luego, reclamar. Porque si no lo pides, el árbitro no lo va a dar de oficio. Si no lo pides, el árbitro, una vez que emite el laudo, luego no es que le vas a poder ir y pedir 'pronúnciate sobre esto', porque emitido el laudo el árbitro ya perdió competencia. Entonces, es en la primera oportunidad pedirlo. Y claro, pedirlo con 'oye, voy a presentar tal medio probatorio próximamente, voy a presentar una pericia en la audiencia de pruebas', por ejemplo.

A.R.: O sea, te adelantas un poco. Ya, así me queda más claro, profesor porque un profesor me dijo por ejemplo, que podría pedir, si en caso se declare la demanda, luego de admitido el laudo, podías solicitar como una integración del laudo y que el tribunal se pronuncie ahí, no después de haberse producido este acto generador del daño.

H.C.: Si es integración no estoy tan seguro. Dentro de los quince días, estoy en la ley, después de la notificación del laudo cualquiera de las partes puede solicitar la integración por haberse omitido resolver cualquier extremo de la controversia sometida a conocimiento y decisión del tribunal, si no lo ha sometido a conocimiento en el arbitraje ¿cómo pides la integración? Yo ahí me reafirmo en lo dicho, tienes que pedirlo dentro del arbitraje, con una integración después veo complicado que te reconozcan los daños.

A.R.: Tiene sentido, porque va a haber como un pronunciamiento de las partes, que se puedan pronunciar sobre esto.

H.C.: Claro, tú no integras aquello que no ha sido materia de debate, tú integras lo que fue materia de debate y omitiste pronunciarte, ahí integras. Pero si es que no has hecho un pedido, la integración no es una suerte de acumulación de pretensiones, para eso no sirve la integración, para eso no está pensada la integración.

A.C.: Claro, sí profesor. Ahora ya estoy muy segura de lo que voy a poder exponer en la parte resolutiva de la tesis.

\section{Entrevista al profesor Daniel Linares Prado.}

A.R.: ¿La discusión sobre la responsabilidad por el perjuicio que ocasione la ejecución de la medida cautelar en arbitraje, excede lo pactado por las partes al celebrar un convenio arbitral? 
D.L.: A ver, si las partes han delimitado el monto de la responsabilidad, por ejemplo, y eso está fuera del ámbito del convenio arbitral, definitivamente los árbitros, en mi opinión, no van a poder pronunciarse sobre ese tema porque se trataría de una extra petita, o sea, se estaría yendo fuera del convenio asumido por las partes. Las partes son las dueñas.

A.R.: Claro, digamos que la responsabilidad es mayor respecto de la pretensión, me indicó, entonces los árbitros no tendrían por qué resolverlo.

D.L.: Claro, si las partes se han determinado un monto de responsabilidad por la aplicación de una medida cautelar, con lo cual nos llevaría a pensar que es una cláusula arbitral bastante compleja porque han establecido una serie de cosas, incluida la medida cautelar. En ese caso, si es que los árbitros se pronuncian fuera de lo que han pactado las partes estarían en un pronunciamiento extra petita, es lo que te comentaba, entonces estarían limitadas básicamente por el acuerdo de las partes para determinar el monto. Te pongo un ejemplo, si las partes dijeran 'en caso de que se establezca una medida cautelar y la demanda se declare infundada, y la medida cautelar ya no sirviera, desaparece la medida cautelar, entonces si las partes establecieron que la otra parte puede indemnizar por la los daños de la ejecución de la medida cautelar hasta el monto de S/. 1000 000. Pero, resulta que el tribunal resuelve que el monto de indemnización es S/. 1300 000, S/. 1500 000, S/2 000000 o S/. 3 000 000, el tribunal está limitado por el millón, o sea no podría irse más allá de lo pactado por las partes.

A.R.: Y si en el caso no hayan delimitado, por así decirlo, un monto como tal, y sea una cláusula bastante simple que indique que las controversias que se deriven de este contrato se resolverán a través de arbitraje. En dicho caso, ¿el tribunal podría resolver esta controversia?

D.L.: Sí, claro, y podría determinar los daños y perjuicios, si es que la cláusula arbitral estableciera un monto de reparación por efectos de la aplicación de la medida cautelar. Pero, eso dependerá básicamente de la contracautela, o sea, ¿cuáles son los requisitos de una medida cautelar? Que existan varios temas.

A.R.: Verosimilitud del derecho.

D.L.: Apariencia de derecho y el peligro en la demora, y en el caso de las medidas cautelares judiciales, porque así lo establece el Código Procesal Civil, la contracautela. En el caso de la ley de arbitraje, no está establecido contracautela, pero los árbitros si 
pueden fijar una contracautela. Entonces, si la cláusula arbitral es así de escueta, y se les pide una medida cautelar, los árbitros pueden solicitar una contracautela. Normalmente, lo que se debe solicitar es una contracautela real, o sea, algo que se ofrezca en garantía, una fianza, una letra de cambio, a la que podríamos llamar una garantía real, algún tipo de garantía para efectos de los daños y perjuicios que pueda ocasionar la medida cautelar. Ahora, una caución juratoria, que es lo que se usa a veces en el Poder Judicial que es bastante compleja.

A.R.: Claro

D.L.: En el caso del arbitraje, no debe usarse porque es muy simple.

A.R.: Sí, no garantiza mucho, nada en realidad.

D.L.: Sí, en realidad te metes en otro lío.

A.R.: Sí, es bastante complejo, ¿no? Decir, yo te pago si en caso si en caso sales dañado. $Y$ en realidad realmente a veces ni dinero tiene. $Y$ qué problema para la parte que ejecutó la medida cautelar.

D.L.: Claro, ahora tienes un escenario especial, porque si se trata de una medida cautelar previa al arbitraje, y tú estás solicitando, por ejemplo, la suspensión de la ejecución de alguna obligación, puedes ofrecer una caución juratoria y el juez te la va a aceptar. Ahora, cuando eso pase a arbitraje, los árbitros se apropian de esa medida cautelar y podrán, o desaparecerla, es decir, dejarla sin efecto, mantenerla o regularla. Porque tú sabes que una de las características de la medida cautelar es que es variable. El tribunal luego de otorgada la medida cautelar puede exigir una caución juratoria, real.

A.R.: Claro, podrían pedir una garantía.

D.L.: Así es, si es que les parece. Decías, ¿otra pregunta?

A.R.: La siguiente pregunta es que si el otorgamiento por la indemnización por los daños ocasionados en virtud de la ejecución de una medida cautelar, ¿es a solicitud de parte o de oficio?

D.L.: La ejecución no, la tendría que solicitar la parte. A ver, tendría que solicitar la parte la ejecución de esa indemnización a los árbitros.

A.R.: La indemnización, esa es de parte.

D.L.: Así es. 
A.R.: La tercera pregunta es sobre los actos generadores del daño. ¿Cuáles serían los actos generadores del daño de la ejecución cautelar que no debió haberse otorgado?

D.L.: A ver, por ejemplo, podría ser en el caso de la no ejecución. Imaginemos el siguiente tema, que es lo usual de muchos arbitrajes, que la parte del contratista normalmente cuando en un arbitraje que tiene que ver con la ley de contrataciones del Estado, normalmente el contratista lo que solicita es que no se le ejecute la carta fianza que pueda haber otorgado por fiel cumplimiento, por adelantos materiales o por adelanto directo. Imaginemos un contrato de obra, lo que normalmente hacen los contratistas es constituir el tribunal arbitral o previo a la constitución del tribunal arbitral, solicitan una medida cautelar para evitar la ejecución de estas cartas fianza. Entonces, el Estado emite una medida cautelar y el Estado no puede ejecutar la carta fianza. Al final de la historia, resulta que el contrato se resuelve por efectos de incumplimiento del contratista, o sea, del que solicitó la medida cautelar, por lo cual se declara infundada la demanda y la medida cautelar, mientras duró el plazo del arbitraje, ha mantenido vigente la suspensión de la ejecución de la carta fianza. Entonces, esto puede motivar varias cosas. Una de las cosas es que la entidad se haya quedado sin el fondo suficiente, o sin el presupuesto suficiente para continuar la obra por administración directa, es decir, la obra se paralizó, por lo cual hay una población insatisfecha y una serie de consecuencias que se producen con esto. Entonces, ahí hay un perjuicio y un daño que tendrá que ser resarcido por el contratista.

A.R.: Reparado.

D.L.: Así es, reparado por el contratista. Al margen de la ejecución de la carta fianza que también es otra historia.

A.R.: Claro, pero en este caso sería, por ejemplo, cuando es declarada infundada, por ejemplo.

D.L..: Cuando es declarada infundada.

A.R.: Y, profesor, yo quisiera consultarle. Lo que pasa es que la ley de arbitraje señala exactamente que el tribunal arbitral podría condenar la indemnización por el daño de la ejecución de la cautelar, cuando el tribunal considere pertinente. Entonces, en un nuevo ejemplo usted me menciona que podría ser cuando sea declarada infundada la demanda. Pero, yendo al Código Procesal Civil, señala también lo mismo, pero hay un proyecto de reforma que indica que no solamente sea este supuesto de conclusión del 
proceso, sino todos los demás. Entonces, usted ¿qué considera si es bastante bueno o no respecto a este proyecto de reforma? Porque yo analizo en la tesis este proyecto, si es dable o no que se incluya todos los supuestos de conclusión del proceso, y no solo la forma de conclusión del proceso principal como tal, sino también del proceso cautelar. Es decir, por ejemplo, que se revoque a segunda instancia por el juez superior, o que el tribunal considere de que esta medida cautelar, cuando el juez la haya otorgado indique 'a mí esta medida cautelar no me parece', entonces, ya no continúa más esa medida cautelar, es decir, la dejamos sin efecto. ¿Considera de que estos supuestos de conclusión, tanto del proceso principal y cautelar, también podría ser actos generadores del daño?

D.L.: Sí, en ese caso sí, porque si la medida cautelar es una medida cautelar, por ejemplo, manifiestamente improcedente, porque o no reúne los requisitos establecidos en la ley o de pronto en el convenio arbitral, y esa medida cautelar no debió haberse aceptado, definitivamente el solo solicitarla y el solo haberla aceptado puede haberle ocasionado un daño. Y, si el tribunal arbitral se encuentra con una medida judicial, que puede suceder, de hecho, ha sucedido, que no resulta procedente y decide revocarla, y se ha otorgado una contracautela, se entra en el supuesto normativo, que es que caída la medida cautelar, se entra a la contracautela. Entonces, ese es el tema. Ahora, las otras formas de conclusión del proceso, ahí tienes varias. Pero, en realidad, las convencionales no entran en esta historia porque las convencionales son las que las partes establecen o transigen si es un acuerdo de parte, o finalmente llegan a alguna conciliación dentro del proceso. Los otros supuestos de terminación anticipada del proceso sí entrarían, o la conclusión final, que es con la sentencia, que son las formas en las cuales este proceso se puede terminar. Ahora, si es una medida cautelar y la medida cautelar va a concluir porque el tribunal ha determinado que la medida cautelar es absolutamente improcedente, o porque la medida cautelar no tiene fundamento, entonces se ejecutará la contracautela que se ha otorgado, entonces ahí hay otra historia. Entonces, ahí sí tendría que actuar el tribunal diciendo, 'Bueno, se ha caído, es improcedente. Ya está, ejecútese la medida cautelar por su propio mérito'. O sea, te obligo a. Ahora, la ejecución es otra cosa, la ejecución ya es otra historia. Ahí sí ya tendrían que pedir auxilio.

A.R.: Al Poder Judicial. Sí, profesor, otra consulta. ¿Usted considera pertinente denominar esas formas de conclusión del proceso 'actos generadores del daño? Porque yo entrevisté hace unos días a un profesor de la universidad, y me indicó que acto generador del daño, él consideraba que era la ejecución misma de la medida 
cautelar y que estos supuestos de conclusión del daño, o sea que son actos posteriores después de la ejecución de la medida cautelar en realidad no son actos generadores del daño, supuestos en los cuales el tribunal se dio cuenta que no se debió haber otorgado esta ejecución de la medida cautelar. Entonces, acto generador del daño como tal, no sería. Fue lo que él me indicó y me generó una duda, porque en el proyecto de reforma, en el CPC, si lo consideran como tal. Pero, entonces, ¿qué considera usted? ¿Sí podría ser un acto generador del daño?

D.L.: A ver, de lo que te he entendido es un tema de definir cuál es el supuesto generador del daño. $O$ es el hecho mismo del ejecutamiento de la medida cautelar o es la conclusión del proceso que determina que la medida cautelar no haya prosperado. ¿Cuál de los dos supuestos generan el daño? En realidad, el acto generador del daño, para mí, realmente es el otorgamiento de la medida cautelar. Lo que pasa es que la medida cautelar nunca fue, no lo es, o nunca fue procedente, en el caso de supuestos de improcedencia. Pero lo que está haciendo el tribunal es decir 'esta medida cautelar nunca fue procedente' ¿y a quién se le genera el daño? Porque, o se genera la suspensión, en el ejemplo que te puse de la suspensión de las cartas fianza o, por ejemplo del no cumplimiento del contrato o el no otorgamiento de la prestación o cualquier medida cautelar que se haya solicitado, es a partir del momento en que esta se otorgó, se notificó o se ejecutó. Entonces, el daño empieza a surgir a partir de ahí, y no del momento en que es declarado como tal. Entonces, el generador de daño parte desde aquí, como cualquier daño. Si yo atropello a alguien, le causo el daño desde la fecha en que lo atropellé, no en el momento en que el juez me dice 'lo atropellaste'. Es más o menos el supuesto que, creo yo, encaja en el proyecto que está por salir, le falta un poco más de afinamiento.

A.R.: Entonces, ¿podríamos definir, por así decirlo, que esas formas de conclusión del proceso son actos que determinan que la medida cautelar no debió haberse otorgado? Porque el acto en sí es generador del daño. El acto generador del daño es la ejecución de la medida cautelar.

D.L.: Exactamente.

A.R.: Me queda bastante claro, profesor. Yo sí lo veía, por ejemplo la declaración de infundada la demanda o la revocación de la medida cautelar por un juez superior o por el tribunal, sí lo veía como acto generador del daño. Pero ahora como usted lo ilustra, realmente me queda bastante claro. La última pregunta es sobre procedimiento. ¿Cuál 
es el procedimiento para la discusión sobre los perjuicios de la ejecución de una medida cautelar en arbitraje?

D.L.: A ver, ¿la ejecución de la contracautela, te refieres? ¿O a la medida cautelar en sí?

A.R.: No, no. El procedimiento para la discusión sobre la indemnización de la ejecución de una medida cautelar en arbitraje.

D.L: Ah, okey. Yo lo veo como un tema incidental. O sea, dentro del propio proceso arbitral, porque todo es parte de las actuaciones arbitrales. Parte de las actuaciones arbitrales es el otorgamiento de una medida cautelar. Si la medida cautelar deviene en infundada, depende en qué momento, porque es una medida cautelar judicial que es asumida por el tribunal, y el tribunal dice 'oye, esa medida cautelar es improcedente, la que te ha otorgado el juez' y la revoca y dice 'okey, revoca y ejecuta la contracautela'. Lo que va a pasar ahí es que se va a producir un tema incidental, dentro del propio proceso, que va a ser el tema de la ejecución de la indemnización por la medida cautelar que entrará en una discusión por el lado de las partes y que los árbitros pueden asumir. Acuérdate del artículo 40, me parece, en la ley de arbitraje, dice que los árbitros tienen la obligación de pronunciarse sobre cualquier incidencia o cuestión que se ponga a discusión dentro del arbitraje. "El tribunal arbitral es competente para conocer el fondo de la controversia y para decidir sobre cualesquiera cuestiones conexas y accesorias a ella que se promueva durante las actuaciones arbitrales, así como para dictar las reglas complementarias para la adecuada conducción y desarrollo de las mismas. Entonces este es un tema especial dentro de la ley de arbitraje, porque es una especie de impulso de oficio dentro del arbitraje. O sea, es una cuestión bien singular porque el arbitraje siempre es dispositivo. O sea, las partes son las que son dueñas del arbitraje, son las que hacen caminar su arbitraje y los árbitros tienen la opción de llevar a cabo. Pero, en este caso, sí le dice 'tu competencia alcanza para pronunciarte sobre todas las cuestiones conexas y accesorias que hay en el arbitraje. Entonces, es tu obligación, y si dentro de esas obligaciones está el tema de la ejecución de la cautela, genial. Si es que hubiera contracautela otorgada, si es que se hubiera hecho ese tema. Si no hay contracautela y hay un tema indemnizatorio, en ese caso habrá que determinar si las partes lo solicitan o no, 'oye, indemnizame por esta medida cautelar' Le tendrán que decir a los árbitros 'anda por ese lado, este va a ser el monto de la indemnización' y cosas por el estilo. Yo lo veo de esa manera. 
A.R.: Pero digamos que el procedimiento en sí, ¿cómo sería? Por ejemplo, la parte lo solicita después de haber ocurrido este supuesto en el que se indicó que la medida cautelar no debió haberse otorgado. Entonces, ¿en ese supuesto recién la parte podría solicitarlo?, ¿podría ser antes?, ¿el tribunal tendría que hacerlo en el mismo laudo, después del laudo?

D.L.: Lo que pasa es que tienes básicamente, hablando de procedimiento, si es que es un arbitraje institucional, lo que determina el reglamento. Si es que el reglamento determina algo, aplicarás lo que dice el reglamento.

A.R.: No determina nada.

D.L.: Si el reglamento no determina nada, lo consecuente es que los árbitros van a tener que dictar las reglas de cómo se va a hacer esta historia. Pero los árbitros, en ese momento, tienen la competencia para decir '¿sabes qué? vamos a establecer reglas para este tema' $Y$ lo puede hacer de manera porque que están facultados para eso. Tienes el otro caso, que no tienes reglas, entonces tienes esta situación en la cual también los árbitros van a decir 'oye, ¿cuáles van a ser las reglas para ejecutar este tema? $Y$ esas reglas pueden venir de distintas maneras. Ahora, con el laudo acaba la novela, si es que no quieres darle una segunda vuelta en el Poder Judicial, una segunda temporada. Pero con el laudo acaba la novela. Ahora, si una vez que, terminado el laudo, ya los árbitros no tienen competencia, salvo que las partes le establezcan competencia para la ejecución del laudo, si las partes le dicen 'oye, ejecuta el laudo' y así se lo ha establecido en el convenio arbitral o se lo ha otorgado en un convenio posterior, entonces, los árbitros tienen una especie de competencia ultractiva fuera del laudo, pueden ejecutar el laudo, pueden mandar inscripción, pueden hacer oficios, una serie de cosas. Pero, si no tienen competencia, no van a ir más allá del tema del laudo. Entonces el procedimiento para la determinación de este tema, si se pone esto en conocimiento va a tener que ser dentro del arbitraje, hasta que este tema concluya. Es más, los árbitros pueden pronunciarse sobre la medida cautelar en el laudo. Es decir, impugnada la demanda y en consecuencia improcedente la medida cautelar, déjese sin efecto la medida cautelar y fíjese, si es que no hay un parámetro de ejecución de una contracautela y las partes han admitido que se puede establecer de una indemnización, pueden fijar inclusive la indemnización de una medida cautelar en el laudo. Ya hay un tema de cómo lo ejecutan. Te vas al Poder Judicial, si quieres, a ejecutar el monto que se te determine. 
A.R.: Profesor, ¿qué pasaría si en el supuesto en el que te das cuenta de que esta medida cautelar no debió haberse otorgado sino hasta la declaración de infundada la demanda?

D.L.: Lo que pasa es que la medida cautelar como cautelar en sí, tiene un objeto definido, que es tomarle una foto a una situación actual. o dejarla ahí, o evitar que un daño se produzca para efectos de garantizar una sentencia o una resolución que tiene grandes posibilidades de ser declarada fundada a mi favor. O sea, si yo agarro y le digo 'voy a suspender la ejecución de las cartas fianzas a través de esta medida cautelar, tengo la expectativa fuerte de que al final de la historia voy a ganar este tema y que efectivamente tuve razón en suspender el tema de la medida cautelar. ¿Cuándo la medida cautelar no resulta procedente? Cuando no tengo fundamento de fondo. Lo que hago es pedir una declaración anticipada, si se quiere, del tribunal, diciéndome 'oye, mantengamos esta situación en particular, hasta que se pronuncie la sentencia final' Ese es el objeto de la medida cautelar. Pero yo no podría decir 'oye, te otorgo una medida cautelar, y llego al final de la historia para que se me declare infundada' No es el supuesto, ¿te das cuenta? No es a lo que voy. Ahí es donde se produce este quiebre, y el tribunal puede decir, cuando ve la medida cautelar 'esta medida cautelar no camina, esta medida cautelar se acaba' No tendría que esperar al pronunciamiento final. Puede que espere al pronunciamiento final, pronto, porque dice 'oye, he visto todo el proceso, declaro infundada la demanda' $\mathrm{Y}$ se cayó la medida cautelar, automáticamente se cayó la medida cautelar. Es un poquito la historia de esto.

A.R.: Claro, o sea, en principio el tribunal tendría que darse cuenta durante el proceso antes de la emisión del laudo para decir 'oye, esta medida cautelar no debió haberse otorgado' Es lo que usted me indica. Pero, aún así, en ese supuesto que a pesar, si el tribunal no se da cuenta hasta que se declare infundada la demanda, ¿las partes podrían solicitar después de haberse declarado infundada la demanda al mismo tribunal esta indemnización por ejecución de medida cautelar?

D.L.: Si es materia del convenio arbitral, sí podría. Y como es toda cuestión conexa, sí podrían pedir. Yo les pediría integración. Acuérdate que todavía quedan cuatro recursos después del laudo. Entonces si es que la demanda ha sido declarada infundada y, por ende, se cayó la medida cautelar, hay un tema vinculado al contrato, que es el tema de la indemnización. Entonces, lo que yo le pediría al tribunal es 'oye, tribunal, ¿sabes qué? en mérito del artículo 40, por lo cual tú tienes que pronunciarte, porque es una cuestión conexa y accesoria al contrato, mejor dicho, a la materia arbitral. Entonces, te pido integración del laudo en ese sentido' $Y$ si es que no 
prosperara el tema, acudir al Poder Judicial y pedir la integración del laudo. En caso de integración, ahí sí tendría la opción yo de pedir un nuevo arbitraje sobre el tema.

A.R.: ¿Y se podría pedir entonces la constitución del tribunal arbitral nuevamente para que discuta sobre ese tema? Si en caso no se logra.

D.L.: Sí, claro. Podrías pedirle al mismo tribunal, podrías conformar otro tribunal arbitral para que se discuta ese tema de la indemnización. Todavía te queda ese camino. Puedes encontrarte con esa realidad, también no es extraño. Por ejemplo, tu contrato fue de USD 100 000, pero resulta que la imposición de la medida cautelar te ha producido el coste de una oportunidad para contratar con otros contratistas, con otros agentes en el mercado, y has perdido USD 1000 000. Y no has fijado una contracautela por interposición de esa medida cautelar, al final el arbitraje donde se declare infundada, y esa medida cautelar se declara abiertamente improcedente te ha generado un daño mucho mayor que tu arbitraje principal. Entonces, ahí tendrás que evaluar y decir '¿sabes qué? Inicia un arbitraje justamente porque es un tema vinculado al contrato y la indemnización va a ser mucho mayor que el contrato principal. Hay casos que se han producido de esa naturaleza, también.

A.R.: Se han iniciado nuevos procesos arbitrales para discutir meramente este tema de indemnización por ejecución de una medida cautelar.

D.L.: Claro, inclusive indemnizaciones producidas por la propia constitución del contrato, ya no hablemos de medidas cautelares. Hablemos de que se declara en un arbitraje, de hecho que tengo un caso de esta naturaleza. Se ha declarado fundada la demanda en relación a un contratista y el Estado, y se declaró infundada la demanda por incumplimiento de obligaciones esenciales por parte del Estado. Pero el tribunal no determinó el monto de la indemnización porque la parte no se lo pidió. En el arbitraje solamente le pidieron que resuelva el contrato por incumplimiento de las obligaciones esenciales del Estado. Al final el monto de la indemnización puede ser mayor que el costo del cumplimiento del contrato. Entonces, ahí se debe iniciar un proceso arbitral por el monto de la indemnización por el incumplimiento del contrato porque este no se ha pedido en el proceso arbitral. Se podría ver en el mismo proceso arbitra porque es un tema vinculado al contrato, salvo que el contrato te lo limite el propio convenio arbitraje.

A.R.: Claro, si la cláusula arbitral indica que, por ejemplo, temas respecto a indemnización no se puede tocar en arbitraje. 
D.L.: Claro, si hay arbitrabilidad objetiva, es decir, las partes han consignado que ciertos temas deban resolverse en arbitraje o la ley limita que solo ciertos temas se puedan resolver en arbitraje. Por ejemplo, en la ley de contrataciones del Estado, tú no puedes ver temas indemnizatorios, porque la ley de contratación del Estado ha prohibido expresamente que los temas de indemnización por el no otorgamiento de adicionales de obra, sea ventilado en arbitraje, tienes que irte al Poder Judicial. Objetivamente se ha prohibido. Lo puedes prohibir vía ley o vía pacto.

A.R.: Claro, limita ¿no? Profesor, otra consulta respecto a esto. ¿Qué pasaría en el supuesto en el que, por ejemplo, se otorga una medida cautelar en el Poder Judicial, antes del proceso arbitral, y el tribunal arbitral no se logra constituir por equis razones? $¿ \mathrm{O}$, por ejemplo, se declare incompetente?

D.L.: Ya, esa medida cautelar se cae.

A.R.: ¿Qué pasaría con los daños?

D.L.: Tienes un plazo

A.R.: Claro, para presentar la demanda y constituir el tribunal. Pero, ¿qué pasa en esos casos en los que el tribunal, en primer lugar, se declara incompetente y en el otro caso el tribunal no se logra constituir?

D.L.: A ver, si el tribunal no se logra constituir dice la norma que la medida cautelar queda sin efecto. Ahí hay un plazo de noventa días, me parece, o sesenta días. Y el otro tema es que si el tribunal arbitral se declara incompetente, te cuento que eso pasó. Un caso bastante sonado donde se aprobó una medida cautelar en el lado judicial, el tribunal asumió la medida cautelar y el proceso arbitral duró casi dos años y al final de la historia los árbitros dijeron 'no, somos incompetentes'. Ahí vino inclusive con toda una historia contra los árbitros, porque los árbitros se han debido declarar incompetentes de frente. El tema era muy evidente. Prefirieron avanzar con todo el arbitraje, con todas sus consecuencias económicas y después de dos años dijeron 'oye, somos incompetentes' Pero vinieron una serie de cosas ¿Qué pasa con la medida cautelar? En efecto, la medida cautelar si es que no logras formar tribunal, se caerá. $Y$ en el caso de la declaración de incompetencia del tribunal, es porque se declara incompetente porque hay un supuesto en el cual los árbitros no pueden intervenir, o está limitado por el convenio arbitral o el convenio arbitral no está formado conforme a las cláusulas o conforme al convenio arbitral, el tribunal arbitral debería ser asignado por la Cámara de Comercio y al final no siguieron el procedimiento 
establecido y cada uno designó su árbitro y les importó muy poco su convenio arbitral, puede ser un supuesto, o algún supuesto de incompetencia del tribunal por alguna circunstancia o razón. Si en ese caso el tribunal se declara incompetente, la medida cautelar va a quedar sin efecto, ¿qué pasa con los daños y perjuicios? Yo creo que podría demandarlos constituyendo otro tribunal arbitral o, eventualmente si no tiene otro tribunal arbitral porque hay algún problema de vicio, nulidad o algo en el convenio arbitral, tendrá que ir al Poder Judicial a reclamar su indemnización. No tiene otro camino.

A.R.: ¿Y si en caso el tribunal no se logra constituir, sería el mismo camino?

D.L.: Si el tribunal no se pudo constituir, sí, yo creo que sería el mismo camino. Si el tribunal no se llega a constituir es porque algo ha pasado, porque se trata de árbitros que son extremadamente negligentes, o tienes un centro de arbitraje que no sirve para nada y no ha logrado constituir su tribunal arbitral dentro de los plazos. Entonces son supuestos bien específicos, si es que el tribunal arbitral no se llegó a constituir, por ejemplo, no eligieron al presidente del tribunal y se les pasó a los árbitros, se les pasó el plazo y hasta ahí llegaron, entonces tendrán la opción, mientras tengas tu término de prescripción, de solicitar la constitución de un nuevo tribunal arbitral, eso no te limita. Lo que va a pasar es que tu medida cautelar se va a caer, si tu medida cautelar se va a caer, lo que pides es una nueva medida cautelar. O sea, trata de mantener tu medida cautelar si es que tienes la razón y explicarle al juez 'oiga, señor juez, ha pasado esto, el tribunal no se ha llegado a constituir pero no es mi responsabilidad, es responsabilidad del centro de arbitraje' para tratar de mantener tu medida cautelar, le puedes pedir 'oye, renueva la medida cautelar' porque el supuesto de peligro en la demora, derecho aparente y el pronunciamiento urgente todavía lo necesitas. Vas a tener que ir al Poder Judicial a decir 'oye, renueva la medida cautelar por favor, ya no es mi responsabilidad que no se haya constituido el tribunal arbitral. Esa es la historia, es lo que tendría que hacer el abogado.

A: Sí, claro. Me ha quedado bastante claro, profesor, muchas gracias por su tiempo.

\section{Entrevista al profesor Alvaro Tord Velasco}

A.R.: Mi tesis es sobre indemnización por ejecución de medidas cautelares en el arbitraje comercial doméstico peruano. Surgen ciertos problemas en relación a este tema, La primera es si la discusión sobre responsabilidad por el perjuicio que ocasiona la ejecución de la medida cautelar en arbitraje, excede o no en lo pactado por las 
partes al celebrar el convenio arbitral. Entendido por convenio arbitral, un convenio simple, que esté redactado. Los conflictos que se deriven de esta relación jurídica contractual se van a absolver a través de arbitraje.

A.T.: Si la responsabilidad por los daños generados por la medida cautelar, exceden el convenio arbitral. Yo te diría que no, porque, tanto el artículo 41 inciso 1 y 8 de la ley y las normas correspondientes de los centros de arbitrajes, por lo menos más utilizados en nuestro medio, como son la Cámara de Comercio y la PUCP, por dar dos ejemplos, también establecen de que el Tribunal en cualquier momento del proceso tiene la facultad, pues, de establecer las responsabilidades y cuantificar los daños derivados de la ejecución de una cautelar que no debió ser concedida, ¿no es cierto? Entonces, si la controversia ha sido sometida por las partes a arbitraje, por ejemplo, una controversia relacionada con la interpretación del contrato, si las partes han pactado de que las cuestiones relacionadas a la interpretación del contrato, o a la nulidad del contrato, son arbitrables, entonces, si se otorga una medida cautelar en el trámite de ese arbitraje sobre esos temas que las partes han pactado, respecto a los cuales han pactado de que si se dan, van a acudir a vía arbitral y no a la judicial, entonces por una cuestión lógica, pero además por la positivización de esa regla tanto en la ley como en los reglamentos de estos dos centros de arbitraje, que los pongo como ejemplo porque son, quizá, los dos más importantes, está claro que la ley, los reglamentos y por una cuestión de sentido común, si se da una cautelar en un arbitraje donde claramente el tribunal está arbitrando sobre una controversia que las partes han pactado de que puede arbitrar, entonces, yo no veo ningún problema.

A.R.: Sí, solo le comento cómo surgió este primer problema de la tesis. Hay artículo pequeño de Castillo Freyre que menciona este problema, dado que la relación jurídica que se origina de la responsabilidad civil por la ejecución de más cautelares es de un tipo distinto a la contractual, es por ello que, según el razonamiento de este profesor, no sería. O sea, no se debería ver en arbitraje. Pero también yo llegando a ese mismo análisis que usted, por sometimiento de la partes de la ley peruana, y también a un reglamento específico de un centro arbitral como tal, yo también coincido con esa conclusión.

Bueno, la segunda pregunta es ¿el otorgamiento de la indemnización debe ser solicitada de parte o de oficio? Porque nuevamente la ley simplemente indica que el tribunal arbitral puede otorgar la indemnización por ejecución de una medida cautelar en cualquier momento del proceso. 
A.T.: Bueno, creo que la ley y los reglamentos no suelen ser tan específicos en ese tema. Pero, yo creo que por un principio general de imparcialidad y de congruencia en la actuación jurisdiccional, yo creería que tiene que pedirlo la parte que considere de que la cautelar le ha generado un daño que no era legítimo. Dudo mucho que un tribunal de oficio, sin que nadie se lo pida, establezca una pretensión de indemnización que él mismo resuelva, ¿no? Te das cuenta del desequilibrio que pueda haber. Lo que sí hay en los reglamentos y en la ley, es el principio de igualdad y también de imparcialidad. Yo creo que si un tribunal, sin que una parte lo pida, le va a otorgar algo, podría parecer que se rompen esos dos principios. Por eso creo que los reglamentos ni lo señalan, ¿no es cierto?

\section{A.R.: La ley tampoco}

A.T.: Son cosas que se entienden, de que así deben ser, ¿no? Entonces, yo creería que no es necesario de que los reglamentos lo digan, y no lo dicen, creo que es un tema digamos de, principios, ¿no?

M.A.: A: Si. La tercera pregunta es ¿cuáles son los actos generadores del daño de la ejecución de una medida cautelar que no debe haberse otorgado?

A.T.: Bueno, yo creo que el acto dañino, el acto dañoso sería la ejecución de la medida cautelar. Una medida cautelar puede ser dictada pero quizás no llegue a ejecutarse, ¿no? Entonces yo creería de que solo una medida cautelar que se ejecute tiene el potencial a dañar a la parte que la sufre, ¿no? Ahora, del universo de medidas cautelares ejecutadas o ejecutables, yo diría que no todas tienen ese potencial o pueden hacer un daño efectivo. Por ejemplo, una anotación de demanda, ¿no? Quizá a ti te moleste que en Registros Públicos haya una anotación de demanda, pero un daño real quizá no exista, porque en el tiempo que la cautelar estuvo anotada, que la demanda estuvo anotada, quizá no hubo ningún negocio en relación al bien que haya sido frustrado por la aparición de esta anotación en los registros. Caso contrario, sí hay cautelares que uno pensaría que normalmente podrían significar un daño, por ejemplo, una cautelar de administración de una empresa. Uno pensaría que si alguien pide una cautelar de esa naturaleza es porque va a tomar ciertas decisiones, y esas decisiones podrían, y seguramente, afectarían a los accionistas que están del otro lado en esta pugna por la sociedad. Entonces, hay cautelares que son muy gravosas, que uno pensaría que difícilmente no generen daños reales, pero hay cautelares que son bastante más leves, como la anotación de demanda, que es al revés, uno pensaría de que la regla es que lo más probable que no haga ningún daño, y la excepción es que, 
quizá por cuestiones de oportunidad, apareció la oportunidad de un negocio y quizás pudo haber sido frustrada por esa anotación. Pero yo diría que, si comparamos cautelares graves, como la administración, versus leves, como la anotación de demanda, yo diría que las posibilidades se invierten, ¿no es cierto?

M.A.: Gracias, pero quisiera comentarle un punto sobre esa pregunta en sí. Lo que pasa es que nuevamente la ley de arbitraje no señala un supuesto como tal, y por eso acudí al Código Procesal, que indica que cuando la demanda se declare infundada, este sería un acto generador de daño como tal, por lo cual, si la demanda se declara infundada, tú puedes solicitar la indemnización por la ejecución de una medida cautelar que no debió haberse otorgado. O sea, como supuesto, que una demanda sea declarada infundada. Eso es lo que actualmente está regulado en el CPC, pero, luego hubo una propuesta de reforma del Profesor Monroy, si no me equivoco, indicando más supuestos de conclusión del proceso y la Profesora Ariano cuestiona de que ¿por qué solo se indican solo supuestos de conclusión del proceso principal como tal, y por qué no se incluyen formas de conclusión del proceso, pero del proceso cautelar como tal? Eso ella propone, haciendo como una crítica a esta reforma, y en el proyecto de reforma del CPC.

A.T.: ¿Y ya se dió? O una que está en... ¿Estás hablando de una reforma que se dio, o una reforma que estaría pendiente?

A.R.: Bueno, le comentaba un poco la historia de lo que se quiere plantear. $Y$ actualmente hay una reforma del CPC de que deben incluirse tanto las formas de conclusión del proceso como tal, y las formas de conclusión del proceso cautelar. $O$ sea del proceso principal y del cautelar como actos generadores del daño.

A.T.: En esa comisión no está Monroy. Entonces, no entiendo a qué vas con lo de Monroy.

A.R.: Solo le comentaba como historia, como poco a poco se ha venido tratando de incluir como un acto generador del daño, no solo las formas de conclusión del proceso principal, sino también las formas de conclusión del proceso cautelar.

A.T.: No entiendo qué tiene que ver la generación del daño por una cautelar, con las formas especiales de conclusión del proceso.

A.R.: La medida cautelar, por ejemplo, si se declara infundada, entonces la medida cautelar no debió haberse otorgado, porque no había suficiente verosimilitud del derecho, por así decirlo. Sé que el análisis es distinto, pero el proyecto lo indica. Si la 
demanda se declaró infundada, entonces no debe haberse otorgado esa medida cautelar. Por lo tanto, esta medida cautelar se revoca, o sea, ya no tiene más efecto. Pero se ejecutó, entonces, ocasionó un daño, ¿por qué? Porque esta medida no debió haberse otorgado en dicho momento. Por ejemplo, cuando una demanda se declara infundada y también hay cuando se declara improcedente, cuando hay abandono del proceso, de igual manera cuando un juez, revoca la medida cautelar otorgada antes del proceso que pudo ser otorgada por un juez o también por un árbitro de emergencia. Digamos que esta medida cautelar es revocada por el juez superior, a nivel proceso cautelar, la medida cautelar no debió haberse ejecutado, pero se ejecutó, entonces ya hay un daño a la parte porque tuvo que asumir esos costos. Luego, también a nivel proceso arbitral, por ejemplo, antes del proceso se dictó una medida cautelar y se ejecutó pero el árbitro dijo no, yo no considero que esta medida cautelar se debió haber otorgado, por lo que digo que esta medida cautelar no siga continuando. Entonces, nuevamente la parte que ejecutó esta medida tuvo que asumir los costos de ejecutarla, cuando en realidad no debió haberse otorgado. Entonces, la tesis que vengo desarrollando se va alineando un poco a esos hechos que le acabo de comentar.

A.T.: Sí, me queda claro de que la cautelar se ejecuta y por las razones que tú señalas, que pueden ser varias, terminan siendo dejadas sin efecto, pongamos el ejemplo, de la sentencia definitiva declare infundada la demanda. Como consecuencia de que un proceso concluya de manera diferente al supuesto de que se declare fundada la demanda, es decir, que se declare infundada la demanda, que se declare improcedente la demanda, que el proceso concluya por cualquier otra forma especial de conclusión del proceso, pero de manera negativa a la parte demandante, porque claro, hay formas especiales de conclusión de proceso que terminan de manera positiva para la parte demandante. Aparte, la sentencia, por ejemplo, el allanamiento, el reconocimiento. Entonces, tenemos que, digamos, calificar bien las cosas. Entonces, del universo de razones por las cuales un proceso concluye, algunas se dan al favor del demandante, algunas se dan a favor del demandado. A favor del demandante, ¿cuáles son?, la sentencia que declara fundada la demanda, y las que acabo de mencionar, por ejemplo, el allanamiento, el reconocimiento. Entonces, en esos casos, obviamente la cautelar fue bien dada. Pero, en el resto de supuestos en los cuales la sentencia es infundada o se emite alguna resolución que concluye proceso equivalente, es decir, que no le dé la razón al demandante, y hubo una cautelar, entonces, para eso está la contracautela, para garantizar esos daños que la 
cautelar ha podido generar en la parte demandada. Ahora, como tú dices, seguramente los costos, los gastos judiciales generados por la cautelar sí, eso tiene que ir sí o sí. Pero, creo que la norma se refiere también a los daños y perjuicios, esos creo que sea automático, yo creo que hay que acreditarlos. Entonces, volviendo a tu pregunta, definitivamente el acto dañoso tiene que ser la ejecución de la cautelar, no solo el dictado, porque hipotéticamente se puede dictar la cautelar y por alguna razón no se ejecuta. Entonces, si no hay ejecución no hay daño, naturalmente. Por eso digo que hay que decirlo, el acto dañoso es la ejecución. Ahora, acto dañoso o potencialmente dañoso, porque como decía hace un rato, quizá hay una cautelar ejecutada, pero que finalmente no genera un daño real. Es como que a ti te atropellaron, pero quizá frenó a tiempo y el golpe te dio justo en un ángulo del cuerpo que realmente no pasó nada, más allá del susto, quizá. Entonces, aquí, un daño relevante para un juicio, no hay. La lógica es la misma con la cautelar, puede haber una cautelar que se dió y no debió darse, sí, pero, pese a ello, puede ser que no haya habido un daño real más allá de los gastos judiciales, puede ser, entonces yo no creo que sea un tema automático. Lo digo también por la práctica judicial, uno tiene que, al pedir la ejecución de la contracautela, uno tiene que sustentar los daños como si fuera una demanda de responsabilidad civil, daño y los demás elementos pero sobre todo el daño, porque los demás elementos serían más de fácil probanza, sin duda, hay relación causal y los demás elementos. Pero, el daño, si no lo acreditas, como cualquier caso de responsabilidad civil, no va.

A.R.: Okey. Pero, digamos que estaría bien esta línea además de la ejecución de la medida cautelar como tal, también los actos que no favorezcan al demandante, pueden ser considerados como un actos generadores del daño.

A.T.: No entendí la pregunta, ¿cuál es?

A.R.: Quisiera saber si esta línea de razonamiento que yo también desarrollo en la tesis, además de la ejecución de la medida cautelar como tal, también pueden ser actos generadores del daño aquellas formas de conclusión del proceso que no sean favorables a quien ejecutó la medida cautelar, por ejemplo, al demandante.

A.T. Ya, pero ¿cuál es la pregunta? No entiendo.

A.R.: Si las formas de conclusión del proceso que no sean favorables al demandante, por ejemplo, infundabilidad de la demanda, puede ser también un acto generador del daño, como también lo señala en el proyecto de reforma. 
A.T.: A ver, a ver, me estás diciendo de que tú estás investigando sobre los daños que genera una cautelar, ¿no?

A.R.: Sí.

A.T.: Entonces, ¿cómo la forma especial de conclusión del proceso podría ser el daño, el hecho generador? No entiendo.

A.R.: O sea, que ese es un acto generador del daño. Lo que pasa es que no es automático, o sea, la ejecución de la medida a nivel proceso cautelar, en sí no genera un daño, o sea los actos que vienen después de la ejecución podrían probar de que la ejecución de la medida cautelar no debió haberse otorgado, por lo que se generó un daño, o sea, un acto posterior.

A.T.: Ya, pero tú estás confundiendo si una medida cautelar debió ser o no otorgada, con el daño. Tú crees que cuando un tribunal declare infundada la demanda automáticamente se cae la cautelar, sí, eso sí es automático. Pero tú, cuando me haces las preguntas, o me conversas, me das a entender de que para ti, eso automáticamente eso genera un derecho de indemnización, y eso no es así, pues.

A.R.: Claro, obviamente que sí tienen que haber los demás supuestos de responsabilidad civil, pero digamos, como un supuesto como tal, o sea, no como un acto en sí, sino como un supuesto, llamándolo mejor, para poder determinar si hay o no daño.

A.T.: No, es que no entiendo bien tu pregunta.

A.R.: O sea, a nivel proceso cautelar, se ejecuta la medida y luego hay un acto posterior. Bueno, este acto posterior serán los supuestos que ocasionaron el daño, porque estos actos posteriores fueron los que señalaron que la medida cautelar, o sea en el proceso cautelar, esta medida no debió haberse otorgado.

A.T.: Ya, si, si el tribunal decide que esa medida cautelar no debió haberse otorgado...

A.R.: Por un acto posterior.

A.T.: ...claro, por ejemplo, el juez otorgó la cautelar, y la parte demandada apeló, pero en ese acto el tribunal se constituyó, entonces, por ley, el juez tiene que mandar el expediente en el estado en que se encuentre. Entonces, quizá el estado en que se encuentra la cautelar es apelación, y quizá el tribunal diga 'oye, en verdad esta cautelar no debió haberse dado', el tribunal revoca la cautelar. Entonces, si entre la 
concesión de la cautelar y la revocación de la cautelar hubo daños, el demandado tiene derecho a ejecutar la contracautela.

A.R.: Claro.

A.T.: Sí, sí claro, así funciona.

A.R.: Ya, entiendo, gracias. $Y$ bueno, la última pregunta sería, ¿cuál es el procedimiento para la discusión sobre los perjuicios de la ejecución de una medida cautelar en arbitraje?

A.T.: Bueno, la ley y los reglamentos que he mencionado, dicen que en cualquier momento se puede hacer. Pero, acá hay un problema. Yo diría que de las cuatro preguntas que me has hecho, las tres primeras me parece que las respuestas son claras, ¿no es cierto? Pero, acá sí no hay una respuesta uniforme, porque pueden haber dos supuestos. En primer lugar tenemos el caso en el cual el tribunal declara o interpreta implícitamente que la cautelar no debió otorgarse. El caso típico es el tribunal que resuelve la apelación de la cautelar. Bueno, en ese caso entonces, según la ley los reglamentos, el tribunal hipotéticamente, antes del laudo, podría declarar de que la cautelar quede sin efecto $\mathrm{y}$, a pedido de la parte que fue afectada con la cautelar, declarar así mismo que la cautelar no debió ser otorgada y que hay daños y cuantificarlos ¿no? Entonces, hipotéticamente, esa resolución se podría dar antes del laudo, como dice la ley y los reglamentos. Pero, ¿cómo ejecutas esa resolución? Entonces, si el tribunal en esos casos, antes del laudo y a pedido de parte, cuantifica la indemnización, y ordena la ejecución de la contracautela, el problema es que la ley de arbitraje y el Código Procesal Civil establecen que el título ejecutivo o el título a partir del cual uno puede pedir al Poder Judicial, la ejecución del laudo, es el laudo. Entonces, ¿cómo vas a ir tú al Poder Judicial con una resolución arbitral que no es el laudo, para evitar embargos, hacer remates, para cobrar la plata de la indemnización, ¿no es cierto? Entonces, yo creo que en esos casos, sí sería práctico que en el mismo laudo se resuelvan no solo las pretensiones relacionadas a la demanda, sino también que ahí mismo se establezcan esto para que en ejecución del laudo ya se cobre todo.

A.R.: ¿En el mismo laudo?

A.T.: Claro.

A.R.: Claro, sería más práctico. 
A.T.: Sí, porque lo otro se podría generar a discusión, ¿no? Y además es mejor que todo esté en un solo documento. Ahora, esto nos lleva al segundo supuesto. ¿Qué pasa si recién con el laudo el tribunal se da cuenta que la cautelar no debió haberse dado? Justamente en el laudo es cuando se da cuenta que es el demandado el que tiene la razón, ¿no? Incluso la ley dice de que si el laudo declara infundada la demanda, entonces la consecuencia lógica es que tiene que dejar sin efecto las cautelares. Entonces, ¿ahí qué va a pasar? Ahí, lamentablemente, va a haber un laudo que solo se pronuncie sobre la demanda, pero, como recién con ese laudo se va a levantar la cautelar, para cuando se liquide la indemnización por cautelar, el laudo ya estará firme, inclusive ya se estará ejecutando. Entonces, ¿a título de qué se tendría que ejecutar esa indemnización por la cautelar mal dada e injustamente ejecutada en un proceso judicial? ¿Sería otro laudo? Creo que ahí está, de las cuatro preguntas, ese es el único tema que me llamaría la atención. ¿Qué pasa con la determinación de la indemnización y su ejecución cuando es en el laudo que el tribunal, bueno, las partes se dan cuenta de que la cautelar va a caer? En esos casos sí podrían haber problemas. Quizá tendría que ser un segundo laudo, porque a diferencia de las resoluciones judiciales, donde tú puedes ejecutar sentencias y resoluciones judiciales, te lo dice Procesal Civil, que te recomiendo que lo tengas en cuenta. El Código Procesal Civil, en su artículo 720, establece cuáles son los títulos ejecutivos. Y, cuando establece cuáles son los títulos ejecutivos no dice sentencias, dice resoluciones judiciales, porque el legislador considera de que una obligación cierta, expresa y exigible, sobre todo si le da suma de dinero, que además tiene que ser líquida o liquidable, no solo se puede dar judicialmente una sentencia, por ejemplo, una sentencia de condena, que diga que el demandado tiene que pagar una suma de dinero, sino también podría darse una resolución posterior, por ejemplo, si la sentencia dice con costas y costos, la típica sentencia que dice 'fundada la demanda, que el demandado pague, digamos, USD 50 000, con costas y costos', en esa sentencia no está liquidada la costas y costos, hay un procedimiento posterior donde la parte ganadora propone costas y costos al juez, y el juez corre el traslado, y la parte perdedora, obviamente va a querer rebajar la propuesta y observa la liquidación, y el juez determina la liquidación, si hay apelación lo revisa la corte superior. Entonces, hay todo un procedimiento donde se respeta el derecho de defensa y de doble instancia para la liquidación de costas y costos. Pero, como ves, todo este procedimiento no coincide con la sentencia, ¿no es cierto?

A.R.: Claro 
A.T.: Entonces, hay casos en los cuales hay resoluciones distintas a la sentencia que podrían tener una obligación de dar una suma de dinero, cierta, expresa y exigible, que, como está en una resolución judicial firme, pueden ser ejecutadas en un proceso ejecutivo porque es un título ejecutivo. Pero, ¿qué pasa con el inciso 2 de este artículo? Dice, los laudos arbitrales y la ley de arbitraje también dice, que uno ejecuta en un proceso, ante el Poder Judicial, uno ejecuta el laudo. Entonces, si la liquidación o la determinación del monto de indemnización por la cautelar después de esta discusión que te digo, porque el tribunal tendría que primero recibir la solicitud de la parte demandada, diciendo 'oye, tribunal, acabas de saludar a mi favor, y en tu laudo, además, has ordenado levantar la cautelar' $Y$ bueno, quizá eso puede demorar, y al final se levanta. Entonces, después del laudo se levantan las cautelares y recién ahí el demandado está en posibilidad de pedirle al tribunal que determine un monto indemnizatorio por esas cautelares que le afectaron injustamente, y que ejecute la garantía, la contracautela. Pero, todo esto se va a dar después del laudo, y el tribunal le va a correr el traslado a otra parte, por derecho de defensa, y lo otro, que no hay daños y si hay es poquito, dirá lo que tenga que decir. $Y$ el tribunal. teóricamente de acuerdo a las normas que hemos visto, que lo dicen, tendrá que fijar una indemnización. Ahora, ahí no hay apelación, habrá reconsideración y se acabó. Entonces, esa resolución ¿es un laudo? ¿No parece, no? Entonces, ¿cómo lo ejecutas? Porque claro, la otra parte no te va a pagar voluntariamente, lo más probable es que no te pague. Entonces, ¿cómo lo ejecutas? porque el tribunal no tiene competencia, el tribunal no puede rematar los bienes del demandado para cobrar. Por eso, la ejecución del laudo la hacen los jueces, no los tribunales, al menos, la mayoría de los casos. Por eso el tribunal no puede hacer el remate ni un lanzamiento de un inmueble. Entonces ese es el problema que creo que podrías evaluar, eso me parece interesante. Yo que sugeriría quizá hacer laudos parciales, las leyes de arbitraje y los reglamentos permiten laudos parciales. Entonces uno puede decir de que el laudo principal se ejecute como el laudo, y que el laudo sobre ejecución de contracautela también sea calificado de laudo. De ese modo, podrás ejecutarlo sin problemas en el Poder Judicial porque de otro modo entonces ¿cómo ejecutas?, porque no existe un procedimiento de ejecución de título ejecutivo llamado 'resolución arbitral' No existe eso, tiene que ser un laudo. Entonces, en los casos en los cuales se determina antes del laudo, yo creo que el tribunal por economía debería incluirlo en el laudo, y los casos donde recién en el laudo te das cuenta que la cautelar no debió darse, bueno, tendrá que haber un laudo adicional para evitar estos problemas. 
A.R.: Me parece bastante bien esta parte porque yo también tenía dudas sobre esto, incluso yo me ponía a pensar ¿qué pasa cuando se da cuenta en el mismo laudo? ¿lo pides al tribunal? Porque puede ser de que también se liquide, entonces, ¿dónde vas? porque al PJ no puedes ir, porque ellos en principio no tendrían competencia para resolver este problema. Pero sí me queda bastante claro. Profesor, solo una pregunta más, si no fuera mucha molestia, tengo una duda sobre este punto, ¿qué pasaría cuando se otorga una medida cautelar antes del proceso en Poder Judicial y no se llega a consolidar el tribunal arbitral, o sea, no se llega a constituir, o por ejemplo, el tribunal no es competente? ¿qué pasaría con esta resolución del poder judicial que se ejecutó y al final el tribunal no se pudo constituir? Entonces, obviamente aquí también habría un daño porque quien ejecutó la medida cautelar está soportando algo que al final no tiene soporte, o sea el proceso principal como tal, ¿podría pedirlo al Poder Judicial? porque no hay un tribunal constituido.

A.T.: Ya, estás hablando entonces de que en el Poder Judicial se otorgó una medida cautelar para garantizar un futuro laudo que el mismo tribunal dijo que era incompetente.

A.R.: Claro, por ejemplo, o no se pudo constituir o no se constituyó. Creo que son supuestos que al final, o sea, el tribunal no puede resolver el conflicto principal.

A.T.: Ya, hay varias razones. Puede ser porque se declaró incompetente, o quizá las partes no pagaron sus honorarios, eso pasa también. A veces los tribunales no se constituyen porque al final las partes no cumplen con los honorarios, y eso también tiene plazos, entonces ya no se constituye el tribunal, pasan los plazos de caducidad de la medida cautelar, que son diez días para presentar la solicitud y noventa días para que se constituya. Entonces, la ley dice que caduca de pleno derecho la cautelar, y si, entre la ejecución de la medida y la caducidad, pasó tiempo y en ese tiempo hubo daños, y el tribunal mismo se declaró incompetente, habría que ver quién es competente, ¿el Poder Judicial? Si es el Poder Judicial, tendría que resolver el juez competente esos daños.

A.R.: Entonces sí podría resolverlo el Poder Judicial.

A.T.: Si el tribunal arbitral no es competente, entonces lo más probable es que sea competente el Poder Judicial.

A.R.: ¿Y cuándo no se logra constituir el tribunal? ¿También? 
A.T.: Depende, porque normalmente eso ocurre por desidia de las partes, o sea, un tribunal no se constituye porque las partes no cumplen con los plazos, no pagan los honorarios. O sea, es difícil que un tribunal no se constituya, si no lo hace es porque algo está pasando con las partes. Si las partes cumplen con sus obligaciones y el tribunal no se constituye es por razones que serían muy raras, que el centro de arbitraje no funcione, eso es raro. Y, si los árbitros no aceptan sus encargos, bueno, hay una lista larga de árbitros en el centro, como tú puedes elegir también el abogado que quieras. Entonces, veo raro que no se constituya por razones ajenas a las partes. Entonces, si la razón, que es lo más probable, es la desidia de las partes, entonces, digamos, y después quien fue afectado con la cautelar reclama, entonces ahí tendrá que reclamar ante la jurisdicción competente. En ese caso, si ese tribunal que nunca se constituyó, iba a ser el competente, entonces habría que seguir el mismo camino. Pero, si como dices, nunca se constituyó, quizá por desidia de ambas partes, veo difícil de que una de las partes quiera constituirlo solo para ello. Ahora, si los daños son cuantiosos, quizá tenga incentivos para hacerlo. Yo he visto casos en los cuales una cautelar se dio en judicial, y la parte a quien le favoreció la cautelar inició el arbitraje pero no pudo constituirse el tribunal porque tuvo problemas económicos y no pagó y el arbitraje cayó. Sin embargo, la parte demandada que en ese arbitraje iba a plantear una reconvención decidió iniciar su propio arbitraje, y de ese mismo arbitraje pidió al tribunal que deje sin efecto esa cautelar, que se había iniciado para otro arbitraje en realidad. Pero, como el asunto era conexo, el tribunal consideró de que era competente, entonces sobre la cautelar, el juez se lo mandó y el tribunal consideró de que la medida había caducado. Por eso, y la parte que era demandada, ahora demandante, le pidió que cumpla con los requisitos de la ley, del reglamento, que cuando uno pide la ejecución de la contracautela, tiene que acreditar los daños. En ese caso, cuando estaba a punto de acreditar esos daños, las partes empezaron a llegar a un acuerdo y suspendieron un arbitraje. Ahora no sabemos cómo va a terminar eso porque está suspendido. Ese es un caso, por ejemplo, digamos que ejemplifica lo que tú estás diciendo, de que un tribunal, cuando un acto no se constituye, la parte afectada podría iniciar otro arbitraje y ese tribunal ser competente en la ejecución de la contracautela, ¿no es cierto?

A.R.: Sí, otro arbitraje. Y, si en caso no se realice otro arbitraje porque no hay ningún conflicto, digamos, extra, por ahí que resolver, ¿no cabe la posibilidad de que este pequeño conflicto sobre los daños de la ejecución de la medida cautelar se pueda 
solicitar al Poder Judicial? ¿No cabe esa posibilidad? Porque, si no hay un conflicto que resolver en arbitraje que sea conexo a estos daños no podría, ¿no? solicitarlos.

A.T.: Ah, ya. Tú dices ¿qué pasa si la cautelar se efectuó y el tribunal no se constituyó por razones distintas a la incompetencia? ¿no es cierto?

A.R.: Claro

A.T.: O sea, no se constituyó simplemente. Con lo cual, teóricamente, ese tribunal sí podría ser competente. Pero, claro, la parte demandada ya tuvo un daño y quizás alguien tenga que ordenar el levantamiento de la cautelar, ¿no es cierto?

A.R.: Claro

A.T.: Entonces, si no se constituyó, y lo único que quiere es que se levante la cautelar y se ejecute la contracautela, el levantamiento de la cautelar la podría hacer el mismo juez, porque la ley de arbitraje dice que el juez es competente mientras no se constituya el tribunal. Y, si acá no se ha constituido el tribunal, pero la cautelar ya caducó, se entiende que el juez sigue siendo competente.

A.R.: Okey. Entonces, ¿el mismo juez puede resolverlo?

A.T. ver, ¿qué dice la ley? Porque si no hay tribunal constituido acá no se aplica el reglamento, se aplica la ley. Dice, es el artículo 47, inciso 4, 'las medidas cautelares solicitadas a una autoridad judicial antes de la constitución del tribunal arbitral, no son incompatibles con el arbitraje. Ejecutada la medida, la parte beneficiada debe solicitar el arbitraje a los diez días siguientes y el constituido el tribunal arbitral tiene que remitir, lo que dice el inciso 4 que las medidas cautelares por una autoridad judicial de la constitución no son incompatibles con el arbitraje. Lo que está diciendo es que después de la constitución si es incompatible.

\section{A.R.: El Juez puede}

A.T.: Si el tribunal no se constituye, por lo tanto, dentro del plazo de noventa días la medida cautelar caduca. Pero, si bien la caducidad es de pleno derecho, alguien tiene que declararla y alguien tiene que ejecutar el levantamiento de la cautelar, sobre todo si es una cuestión, por ejemplo, de registros públicos, que necesitas un parte judicial para levantarla. Entonces, ahí por mandato de la ley, el juez sigue siendo competente. Ya, ahora, después de eso, ¿qué haces con la indemnización? Si lo que quieres es no iniciar una controversia distinta. Bueno, yo creería que podrías pedirle al mismo juez la ejecución de la contracautela. En el caso que yo te he contado, sí hay una pretensión, 
una pretensión obviamente acompaña la de ejecución de contracautela. Pero, en este caso no hay una pretensión al tribunal arbitral, habría que preguntarse si la determinación de la indemnización por una cautelar pre arbitral sería una pretensión dentro de los ajustes del convenio para discutirla en vez de que la resuelva el mismo juez. Bueno, esa es una pregunta, digamos, que sí habría que analizar de manera pormenorizada, las reglas de la ley, para determinar su respuesta. La verdad que ese sí es un caso bastante curioso, por eso ahorita no tengo una respuesta, tendría que revisar la ley porque es un caso bastante raro. Tienes una cautelar, el tribunal no se declara incompetente, simplemente no se constituye, y la otra parte no quiere iniciar un arbitraje. Entonces, ¿quién determina la iniciación de la ejecución de una contracautela? ¿habría que iniciar un arbitraje para eso? En principio parece poco económico, creo que debería ser el mismo juez, pero habría que revisar la ley a ver si el legislador ha señalado algo. Bueno, eso sí, no lo he estudiado ahorita y esa es una pregunta pendiente de responder.

Muy bien, a ver, un supuesto tan específico, la ley de arbitraje no lo regula y claro, no está mal. Las leyes de arbitraje son bastante escuetas, tienen pocos artículos. Deja un espacio amplio para que los árbitros, a diferencia del Código Procesal Civil que tiene casi mil artículos. Entonces, no me parece raro que la ley no lo regule porque es una cosa rara, pero, como ves, creo que es un caso en el cual el asunto no llega al arbitraje. Entonces, quizás sea el mismo juez quien deba...

A.R.: Que pueda resolver

A.T.: Eso. Y el Código Procesal Civil lo único que dice es el tema de la ejecución de la contracautela, justamente en los casos en los cuales la demanda por cualquier razón no ha sido estimada y ello puede generar daños. La ejecución de la contracautela está regulada en 613 del Procesal Civil, dice 'en caso de ejecución de la contracautela, esta se actúa a pedido del interesado' $Y$ acá tienes un argumento a favor de la segunda respuesta, de que debe ser de oficio o debe ser de parte. En el ámbito procesal, claramente es de parte, porque lo dice el artículo 613. 613 último párrafo, bueno, penúltimo en realidad. ¿Puedes?

A.R.: En caso de ejecución de la contracautela, esta se actúa, a pedido del interesado, ante el juez que dispuso la medida y en el mismo cuaderno cautelar; el que resuelve lo conveniente previo traslado a otra parte.

A.T.: Bueno, ahí está la respuesta. Muy bien. 
A.R.: Una última pregunta, cuando yo me refería a actos generadores del daño, en la reforma lo señalaba como tal, por eso lo indiqué. Pero ahora, conversando con usted, ¿creo que el término más apropiado sería aquellos supuestos que determinan que la medida cautelar no debió haberse otorgado? Y no denominarlos actos generadores de daños.

A.T.: No entendí bien tu pregunta.

A.R.: Lo que pasa es que la tercera pregunta que le comenté era sobre los actos generadores del daño, y usted me dijo que el acto generador en si, en este caso, es la ejecución de la medida cautelar. Pero, lo que yo le comenté, ¿usted considera que son actos que dan a conocer que la medida cautelar no debió haberse otorgado, verdad? Porque yo tomé como base esto por la reforma, pero ahora como usted lo señala creo que tiene razón, el acto generador como tal es la ejecución, pero estos supuestos, por ejemplo en conclusión de proceso y demás, sería como actos posteriores que dan a conocer que la medida cautelar no debió haberse otorgado.

A.T.: Quizá pueda haber opiniones distintas, porque la doctrina es muy variante. Pero, lo que yo creo, lo que yo opino, es de que ¿las cautelares te pueden dañar? Sí. La pregunta es, si al final ese daño es legítimo o es ilegítimo. Si a ti te embargaron durante dos años y al final tú pierdes, ¿es un daño legítimo o ilegítimo?

A.R.: Legítimo.

A.T.: Es un daño legítimo, pues, porque perdiste. Te embargaron bien. Incluso ese embargo se convierte en una medida de ejecución y te rematan, y ahí se cobra el demandante. En cambio, si el demandante perdió en la sentencia final y la cautelar se levanta, ¿los daños de las cautelares fueron legítimos o ilegítimos?

A.R.: llegítimos

A.T.: llegítimos, ¿cierto? Pero, si te das cuenta, el daño es uno el daño es cuando ejecutaron la cautelar. Lo que tú hablas de estos supuestos, viniendo hacia el final se determinó que fue un daño bien hecho o mal hecho. No hay que confundir. Entonces, una cosa que a ti te peguen en una discoteca, ¿ese es un daño ilegítimo? Es un daño ilegítimo. Pero si te subes a un ring de box y te pegan en un ring de box, ¿hay daño? Claro que hay daño. Pero, ¿es ilegítimo? No, es un deporte.

A.R.: Claro 
A.T.: Entonces acá hay lo mismo. ¿Daño vas a tener? Sí, la cautelar te puede hacer daño, es al final que veremos si fue un daño antijurídico o no antijurídico. Esa es la parte de la responsabilidad por cautelares que se verá al final, pero el daño si existe? Existirá desde el día uno de la ejecución. Será al final, con los demás elementos de la responsabilidad civil, si el daño, además, fue antijurídico. Por ejemplo, ¿cuál sería un caso de antijurídico? Que la demanda sea infundada, o que haya otra de las causales de conclusión de proceso que tú señalas, que son desfavorables al demandante. Por ejemplo, una excepción que se declare fundada, ¿no es cierto? Por eso, hemos confundido, desde mi óptica, daño con antijuridicidad

A.R. Claro, entiendo. Muchas gracias, profesor, me ha quedado bastante claro. 